\title{
Borçlar Hukukunun Hakiki Kaynakları
}

\author{
Vasfi Raşit SEVIG
}

1. - Montesquieu «Esprit des lois» sinın nukaddemesinde ve ikinci kitabtnın 3 üncü faslında «insanların, yalnız fantezilerj tarafından sevk ve idare edilmediklerini» yaptıkları kanunların kendilerine bir takım hal ve şartların heyeti umumiyesi tarafından inlâ (dikte) edilmekte bulunduğunu ögretti:

«Evvelâ insanları tetkik eyledim, kanunların ve örf ve âdetlerin bu sonsuz çeşitliliği arasında bunların yalniz fantezileri tarafindan sevk ve idare edilmediklerine inandım.». (Mukademe Sahi. V.)

«Kanunlar, memleketin fizikine ikliminin dondurucu, yakıcı veya mutedil olmasına, arazisinin kemiyetine, vaziyetine, büyüklügüne; halkının hayat tarzına: çiftçi aveı, çoban olmasına bağlıdır. Teșkilâtının kaldurabileceği hurryet miktariyle; halkının diniyle, temayülleriyle, zenginlikleriyle, nüfuslarının sayısiyle; ticaretleriyle; âdetleriyle tavı ve hareketleriyle ilgilidir.»1. Kitáp 3 fasıl sah. 6,17.

Montesquieu'nun bu sözleri hukukun kaynağını şekli kaynak ve hakiki kaynak olmak üzere ikiye ayırdı. Prof́esör Bonnecase Kanun koyucusunun iradesine sekli kaynak adını verir; kanun koyucusuna yaptığ kanunu dikte etmiṣ bulunan içtimâ̂, ahlâkî ve iktisadî amill rre de hakiki kaynak ismini verir. Profesör Geny hakiki kaynaga «muta» (veri) der; bu veriye göre inșada bulunan șekli kaynaga da (yapım, cizim) der.

Binaenaleyh bu yazıda borçlar kanunun bir taraftan iktisad ile diğer taraftan ahlak ile olan münasebetlerini araştıracağız. İktisadî (ekonomik) ve ahlakí mutalaların borçlar hukukunun teșekkülü ve gelișmesi üzerindeki tesirlerini göstermeğe çalıșacağı.

Borçlar hukuku ile ahlakın münasebeti son zamanlarda Paris hukuk fakültesinin en meşhur profesörlerinden bulunan Ripert tarafindan incelenmiş ve «la règle morale dans les obligations civiles adl mewhur eserinde derli toplu bir halde ifade edilmşitir. Bu eser yayılmadan evvel 
Paris hukuk fakültesinde Doktora sınıfında ders olarak verilmiști. Türk: çede Ord. Prof. Esat Arsebük'ün Hukuk İlmini yayım Kurumu Konferanslar serisinin $23 \mathrm{~N}$ : broşürü ile yayınlanmış olan» Medenî Hukukta ahlâk kaidesinin rolü» adlı konferansı vardır.

Borçlar hukukunun iktisad ile olan münasebeti hakkında pek çok eser vardı; bunlardan görebildiklerim ve mevzu ile doğrudan doğruya ilgili bulunanlar șunlardır:

«Pierre Bonnet: «Le droit en retard sur les faits»; «Henri capitant: Les transformations du droit civil depuis 50 ans»; «De Loynes: Le code civil et le credit» (livre du centenaire du code civil tIp. 363). «Lyon Caen: De I'influence du droit commercial sur le droit civil» (livre du centenaire du c.c.; «René Maunier: Droit et economie politique»; «Tissier: le code civil et les classes ouvrieres» (le livré de cent. du c:c:); Virgile L. Veniamin; Essai sur les données economiques dans I'obligation civile»; Gand ve Liege üniversiteleri profesörlerinden «Jean Van-Houtte» Les repercussions de I'economie dirigée sur les institutions du droit privé» adl raporu (Annales de droit commercial 193 No.4). "Savatier: les contrats et l'économie dirigee» ( $\mathrm{Du} \mathrm{d}$. c. au d. p.) Bu eserlerde de geniş bir bibliyografyaya rastlanmaktadır.

Iktisadın Milletler arası, bir konu bulunmasına rağmen, hukukumuz üzerindeki tesirini ayrıca türk noktai nazarından da tetkik etmeğ isterdim; millî korunma kanunu ve tatbikatı bu hususta oldukça zengin bir malzeme verebilirsede o dagink malzemeyi nasıl tedarik edebilmeli ? Güdümlü iktisadın hukuk üzerindeki tesirinin pek de devamlı olmasına bu günkü siyasî durumun imkân vermeyeceği de gözükmektedir.

2. - Ripert, adını yukarıda zikreylediğim eserinde «ahlâk kaidesinin bugünkü kıymetini hukukun borçlara ait olan kısmında aramagı kast ediyorum, dedikten sonra saleilles'in bir sözüne dayanarak... her șey Sa: leilles'in müşahedesinin doğruluğuna inanmağa: mukaveleler ve borçlar hukukunun mücerret, mantıkı ve müstakar (yerleşmis ve değișmeyen) karakterine inanmağa sevkeder... Borçlar münasebetinin iddia edilen matematik karakteri, hukukcular için borçların ahlakî kıymetini tetkik etmemeğe bir bahane olmuştur; Ve çünkü nihayet borçlar nazariyesinin bu istikrarı ve zahiri yeknesaklığı acaba burada ahlakın hukuka verdiğ kuv vetin bir neticesi değil midir. Dünyanın hiristiyanlık fikrinìn galebesinden beri tanımış ve kabul eylemiş olduğu yeni ahlâk acaba, eski Roma borçlar nazariyesini. en değișmez gibi gözüken görünüșünün arkasından derin bir tarzda değiștirmemiș midir?... Hukukî alem kendini, Pratik ve aklî (makul) mutalalar üzerinde ve her türlü ahlakî endişeler... dl , 
şında ne derecede düzenleyebilir? Iradelerin ve faaliyetlerin kanunî neticelerini tanzim, sermaye ve hizmetlerin mübadelesini düzenleme bahsinde mücerrẹt hukukî inșaların oldukça müphem bir ülkü veya iktisadî zaruretler üzerinde yükseltilmesine ve sonra hukukî münasebetler muadeleleri (denklemleri) yazarak eglenmeğe v onları değiştirmeğe imkân var mıdır? Yoksa acaba birbirine hukuk bağı ile bağlı bulunan alacaklı ile vereceklinin aynı cemiyete mensup ve yüksek bir ahlakın onları kardes diye adlandırdığını unutmamak mı lâzımdır; bunlardan birinin haklara ve diğerinin borçlara ancak ahlak kaidelerinin bir diğerinden menfaat ve hizmet elde etmeğe müsaade eylediği veya her halde o diğere zarar vermeği yasak etmediği nisbette malik olacaklarını hatırlamak mı lâzım. dur.»

Diğer taraftan bazılarına göre hukuk içtimaî hayatın sadece șeklidir; iktisad ise o içtimaî hayatın muhtevasıdır.» (Ripert; No. 2 sah. 3-6)

«Jean - Van - Houtte» de «hukuk dünyanın bütün memleketlerinde, kimi mahallî kimi evrensel olan çeșitli amillerin tesiri altında gelișmektedir. Evrensel olan âmillerin en kuvvetlisinin ekonomik âmil olduğunda hiç șüphe yoktur. Geçen asır zarfında kanunla liberal ekonominin tesirine tabi olmuş bulundukları gibi bugün de güdümlü veya düzenlenmiș iktisadın yeni doktrinleri bütün memleketler kanunları üzerinde tesir eylemektedir.» der.

Binaenaleyh, bu zıd iddialar karșısında tereddüde düșen akıl borçların daimî tekamülünü sağlayan unsur ve amillerden üstünlüğün ahlakta veya iktisadda bulunup bulunmadığını araștırmağa kalkıyor.

Dünya bir yenileşme çağına girdi, ve yeni bir çăga ayak bastı .Çeyrek asır içinde arka arkaya gelen iki cihan harbi cihanı korkunç bir tarz. da sarsdı. Atatürkümüz «büyük hadiseler büyük inkılablar yaratır» demiștir. Mihverinden oynamıș ve temelleri sarsılmıș dünya kendine yeni bir temel bulmak ihtiyacile kıvranıyor ve bir çok hayal kırıklığ ona, inanmış olduğu bir çok prensiplerden yüz çevirtiyor. Yeni bir felsefe hayatın, umumiyetle bir hareket olduğunu öğretti. Bergson «L'evolution créatrice» inde bu yeni felsefeyi bildirmeden çok evvel şark ve bahusus Türk dünyaya (dön ya) demek suretile bu daimî kararsızlı̆̆ı: bu daimî hareketi Bergson'dan daha az bir belagatla ifade etmiș bulunuyordu. «Hayatın özel tecellileri (gözüküșleri) bu oynaklı̆̆ esefle kabul ediyor ve daima bu hareketten geride kaliyor. Hareket ilerliyor; hayat yerinde saymak istiyor. Gelișme umumiyetle ve mümkün olduğu nisbette düz çizgi balinde olacaktur.» (Bergson sah. 139). 
Bu umumî ilerleyiș arasında hukukcunun bir metin üzerinde tepinmesi neye yarar? Cemiyet içinde geçen hayatın basit bir aynası olan hukuk aynı gelișmeye ve değişmege mahkumdur; tıpkı esen ve geçen bir ruizgârın kaldırdığı toz kirdibadları gibi, hayatın peşinden sürüklenmeğe mecburdur. "Nasıl canlı mahlûkların organizmaları (uvziyetleri) kendi hayatının genel kanununa uymakla beraber onları bilhassa derin ve faal bir değișmeğe maruz kılan devreler geçirirlerse milletlerin tarihinde de bazı devrelere rastlanır ki o devrelerde fikirler ve müesseseler tekamülün genel kaidesine tabi olmakta devam etmekle beraber, özel bir değișmeğe uğrar.» Duguit'nin «Kamu hukukunun değișmesi» adındaki kitabında (sah. XV, XVI) ortaya attığı bu hakikatı türk milleti kendi yakın tarihinde daha sarih bir tarzda görmektedir. Türk milleti, tanzhimattanberi vicdanına ve izanına durmadan şu korkunç suali sormaktadır: «ölmek mi, değișmek mi?». Altı okun biri olan inkilâpçılık Atatürkün bu soruya verdiği cevaptır. Yalnız bugünkü dünyanın böyle bir değișme devresinde bulunduğunu da iyi anlamaklığımız lâzımdır. Cemiyetler normal bir tekamülün daimî bir konusudur. Fakat nasıl tarihimizde tanzimatı açan devir Osmanlı cemiyetinin normal bir tekamülü olmayıp derin değișmeler yaptıran istisnaî bir an idise bugünkü dünya da normal bir tekamül seyrinde bulunmayıp derin değişikler içindedir. Fakat acaba dünyanın çehresini değiștiren, iddia edildiği gibi yalnız iktisadî vazîyet. midir? G. Morin «la révolte des faits contre le code» adlı eserini iktisadî olayların üstünlüğünü göstermek için yazdı; Yani iktisadî mutalar o mutalara uygun yeni bir hukukî rejim icabettirdiği ve yeni mevzu (positif) hukukun cevherini bulmak için iktisadî teșkilâtları yok̉lamak kâfi geleceği iddia olundu.

Acaba iktisad hakkındaki bu görüşler Karl Marx'ın meșhur olan tarihi maddiyetciliğinin yenileșmesi ve yenileștirilmesi midîr? Yanî Karl Marx'in nazariyesindeki mübalagalı tarafları attıktan sonra iktisadî değişmeleri hukukun tekamülü üzerinde kesin bir tarzda müessir bir âmil olarak kabul etmek midir?

Hukuk, ve bahusus onun malî kısmı olan ve mala taalluk eden borçlar hukuku gidasını yalnız iktisadî kaynaklardan almak suretile mi gelișir?

Güçlük yalnız bu soruyu cevaplandırmakta değildir. Bu suale hayır denebilse dahi borçlar hukukuna iktisad kadar müessir bir amil olduğu iddia edilecek ülkünün mahiyetini nasıl tayin edebileceğiz? Ripert, zikreylediğim meşhur eserinde diyorki: «Mevzu hukukun (positif hukukun) az çok adalet fikrine istinat eylediğini herkes bilir ve binaenaleyh mü- 
esseselerden çoğunun bu fikri tatmin etmek zaruretine istinat eylemek. te olduğunu ispat emek te bir ișe yaramyacak gibidir. Ahlâk kaidesinin hukuk kaidelerinin kanun koyucusu ve yargıç tarafından pratik inșasında haiz bulunduğu nüfuz ve tesiri araștırmağı iddia eylediğim zaman ah. lâk kaidesi tabiri ile bilmem hangi müphem adalet ülküsünü kastetmiș olamiyorum; ahlâk kaidesi tabirinden kastım modern batı cemiyetlerini idare eden ve din, akıl, vicdan tarafından teklif edildiği için riayet edilen veya itiyat neticesi yahut insana hürmetten ötürü sayılan o pek vazhh kanundur.» (No. 2 sah. 5).

Ahlâk, adalet, din, akıl; vicdan kavramlarının birbiri içine girmiş kavramlar olduğunu anlamak için Ripert'in nakleylediğim sözleri bașlı bașına kâfi gelir. Acaba hukukun tekamülü üzerinde müessir olan ahla. kî unsurun tayinindeki bu güçlük onu, düşünen kafalara emin bir sıginak olarak göstermeyor ve yese, ümitsizliğe düşmüş akil çaresiz olarak iktisadî değișikleri hukukun tekamülünün biricik hakiki kaynağı olarak kabul etmek zorunda mi kaliyor?

Hukukun inșassında, daima bir rehbere ihtiyaç duyulmuştur, bir zamanlar allah ve bir zamanlar akıl o aranılan rehber olmuștur. Hukuk ilminin teknikcileri uzun zaman ilahî bir prensibi teyid eylemekte olduklarını veya zaman ve yer değișikliğini kabul etmeyen bir tabii hukukun bir numunesini gerçekleştirmekte bulunduklarını sanmışlardır. Bugün dahi hukukun inșasına tekrar tabii hukuku mimar kıllyorlar; yalnız yeni tabii hukuk ile eski tabii hukuk arasında muhteva itibarile: içi, içinde olanlar itibarile bir fark yapiyorlar; Stammler «tarihi maddiyetcilik noktasından iktisad ve hukuk» adlı eserinde muhtevası değișen bir tabii hukuk kabuleder. Saleilles, «Ecole historique et droit natural» adl yazisinda Stammlerin bu fikrini kabul eyler. "Science et technique en droit prive positif» adlı eserinde tabii hukuku «daha ziyade küçültülemeyen, daha fazla basite irca edilemeyen bir en așağı had» olarak kabul eden Geny, Saleilles'in hukukî eserleri hakkında çlkartılmış eserde, mumaileyhin zikreylediğim yazısının özetini verirken der $\mathrm{ki}$ : «yeni çımış ve hukukun ilmî felsefesine az çok ilgili bulunan bir çok eserlerin kendisine telkin eylediği düșünceleri anlatmak bahanesile» tarihi mektep ve tabii hukuk» ismi gibi bir az muammaya benzeyen bir adla yazdığı makalede Saleilles, bu hususa dair ve nazarında esash olan telakkilerini mizana çekiyor ve adeta vicdanını yeniden yargılıyor. Saleilles müşahede metoduna olan güveninden bir șey feda etmemiștir; hukuku daimî bir tekamüle tabi içtimaî bir hadise olarak telakki etmekte devam ediyor. Fakat tarihi mektebin ne hatalarını saklıyor ne de hukukî nizÆimın ob- 
jektif temelini teșkil edebilmekteki esaslı aczini gizlìyor. Bununla beraber tamamile aklî veya ahlakî bir ülküye kendini tevdi etmekten de sa- kınıyor. Akla veya mutlak adalete dayanan tabii hukuka gelince, Saleilles onun sadece prensip koymaktan bașka bir rolü olmadiğını ve o prensibin inkișaf ve tekâmülünü sağllyamadığın kabul ediyor. Hatta tabii hukukun koyduğu prensibin mücerret bir tatbik șeklini dahi alamadiğını: genel ve sarıcı bir şumülü haiz kaidelerde ifade ve tercümesini bulacak bir mücerret tatbik șeklini dahi alamadığını kabul eder. Nihayet Saleilles, Stammler'in «muhtevası değişen bir tabii hukuk» telakkisine ülkü ile uzlașma çaresini bulur. Akıl ve duygu hakkkın varlığının iddiasını temin eder; içtimaî mutalar da konusunu, maddesini açıklar ve dal budak salmasını genişletir. Fakat Saleilles teisirin objektif unsurları üzerinde israrla durur ve sayılarının ùç olduğunu açıkladığı bu unsurları tabii hukuku gerçekleștirmeğe elverișli bulur. Bu unsurlardan birincisi hukukî kıyastır ki kanun tarafından yeni olarak teyid edilmiş bir adalet prensibinin olaganüstü teșmiline imkân verir. İkincisi kolektif (müșterek olan ortaklașa) bulunan hukukî vicdandır ki iyi ahlakı açıklamakta mühim tesiri vardır. Aläman medeni kanununun 138 inci maddesinin iradenin muhtariyetine sınır olarak kabul eylediği iyi ahlakın açıklanabilmesinde müessirdir (alman medeni k.nun 138 inci maddesi Türk borçlar K.nun 20 inci maddesinin ahlaka (adaba) ait olan kismile 21 inci maddesini ihtiva eder). Ủçüncüsü mukayeseli hukuktur. Saleilles tabii hukukun hassasi olan evrenselligi hukuk mukayesesinde bulur. Saleilles hukukta devaml bir yaratma işini milli hukuku en ufak teferruatinda dahi terakki ettirmeği hukuk mukayesesine tevdi etmek ister» (Sah. 24 25).

Saleilles'in Geny'nin agzından nakleylediğim düșüncelerini iyi duyurabilmek için yazısının içinde rastlanan «tarihi mektep» «tabii hukuk» «kolektif hukukî vicdan» sözleri hakkında șimdiden ufak bir açılamada bulunmak lâzımdır kanaatindeyim. Şöyle ki Almanyada çıkan tarihi mektep hukuk aleminde egemenliği cok çabuk eline aldı. Tarihi mektebin çıkıșı evrensel vedeğişmez olarak kabul edilmiş olan tabii hukuk için çok acı bir darbe ve çok korkunç bir yenilme oldu. Tarihi mektep evrensel aklın yerine halkın kolektif vicdanını ikame eyledi. Savigny hukukun halkın ihtiyaçlarınin tepkisi altinda, onun tesirile tekamül eden adetlerin tabii gelișmesile teșekkül ettiğini iddia eyledi. Binaenaleyh halk ihtiyacının tabi bulunduğu iktisadi olaylar hukukun teșekkülünde kendilerini nazara aldımaktadır. Tarihî mektep bahusus «Puchta»nın ifrata kaçıșlarından sonra nikbete uğrădı: Tekâmül fikrinden hareket eden ta- 
rihî mektep kaza ve kadere: bir fatalisma, vardı ve İhering'in isyanlarını vucude getirdi.

Fakat nikbete uğrayan tarihi mektebin hukuka ve hatta muhaliflerine büyük hizmeti doukmnuștur. Stammler, «hukukun ve hukuk ilminin cevheri» adlı eserinde tarihi mektebi tenkit etmekle beraber daima kendisine eşit kalan, daima kendisinin aynı kalan br tabii hukuk fikrini, tarihî mektebin tesirile redeylemeğe ve muhtevası hiç değişmeyen bir tabii hukuk yerine muhtevası değișen bir tabii hukuk ikame eylemege mecbur kalmıștır. Yine Stammleri, «tarihin maddiyetci izahı noktasından iktisat ve hukuk» adlı eserinde «hukukun muhteviyatı empirik (1) ve tarihi ihtimallerin getirdiklerinin ve verdiklerinin mahsulüdür» dedirtmege mecbur birakmıstir.

Positivizm mektebinin șefi olan Duguit bile (anayasa hukuku cild I. sah. XVII) : «mesele ancak, hükûmet sürenlerin (idare edenlerin) alacakları kararı haddi zatında meșru kılacak șartların tayin edilebilmesi halinde çözülmüsṣ olacaktır; bu çözüm hatta idare edenlerin hemen hemen hepsi tarafından tesvip edilmiş kararları dahi haddi zatında meș. ru kılacak şartların tayin edilebilmesine bağlıdır. Bu șartlar ise, idare edenlere üstün ve onların faaliyetlerini güden ve sınırlandıran, onların faaliyetlerine komuta eden bir hareket kaidesinin tanınmıș ve kabul edilmiș olmasında bulunabilir,» diyor.

Duguit'nin aradığı ve idare edenleri sevk ve idare ederecek olan yüksek prensibi, insanlık doğduğu zamandanberi aramaktadır. Insanhlk hak ile zulmü yani hakszzlığ 1 allahın sesi ve kitabı ile tayin etmek suretile ișe bașladı. Fakat «zaman» bu ilahî bildirmelere pek te uygun düșmeyen kaideleri insanlara kabul ettirdi. Burada mecellenin tabirile kullandığım zaman - değișmesi hukuk kaidelerini de değiștiren zaman - tabirinin yalnız mübadelenin ve ticaretin gelișmesini ifade eylediğini kabul edemem. Müspet hukukun, mevzu hukun inșasında iktisadî mutalaların önemini inkâr etmemekle beraber, inkâr edememekle beraber «zaman» tabirini, iktisada kısaltılmıș derecede dar bir manada alamam. Gerçektir ki mecelle gökten inmiş ve insanlara vahi yolu ile ifșa ve izhar edilmiș bir ilâhi hukukun ifadesi olduğunu idda ediyor; ve insan olan büyük islam hukukcularnnın koydukları insanî hukuk kaidelerinin ilahî hükümlere uygun bulunduğunu da, nefsini islam tahtından haletmemek için, iddia eylemek zorunda kaliyordu. Bu itibarla da esasta, mütemadiyen

(1) NOT. Empirik, aklım muakemesine dayonmayip tercübeve dayanan bigi de. mektir. Türk ata sözleri içinde «Hekin kimdir? bassından gecen» sözü empirik bilginin en güzel iradesidir.) 
değişen hukukun esasta değișmediğini iddia ederken «Zaman» anlamına geniş bir mana vermekten kaçıniyor ve ilk serabını yeni tüllerle süslemekte devam ediyordu. Gökten yere inmiş hukuk, yerin müşterek hayatının mukadderatını paylașmak zorundadır; yerin en pürheves oynamalarına ve dalgalarına onların veznine ve ahengine ayak uydurmak zorundadır.

Meșhur İtalyan filosofu ve son zamanların Bergson ile beraber en büyük filosofu bulunan «Benedetto Croce» nın «iki kiși arasındaki hukukî minasebet bir iktisadî bağdan başka bir șey olamaz». sözii bir hakikat diye kabul edilecekse mecellenin kulandığ1 «zaman» tabiri ancak iktisadin başka bir tarzda ifadesi olabilir. Croce insan ile insan arasındaki münasebetin bir kuvvet bir tazyik münasebeti olabileceğini kabul etmiyor. Insanlar arasındaki münasebeti zormünasebeti kılmak için zaifin kuvvetlinin kanununa buyruk olur demek kâfi gelir. Croce fizik alemde yürürlükte olan kuvvet münasebetinin insanlar arasinda cari olamıyacağını, insanların birbirini yok etmekte menfaatleri bulunmadığını ileri sürmek suretile redeyliyor ve hukukî münasebetin kurulabilmesini (A) nın (B) ye ve (B) nin de (A) ya faideli olmasına bağlı kılıyor. Croce hukuk felsefesini iktisad felsefesine çeviriyor; halbuki hukuk ve iktisad ayrı ayrı şeylerdir. Gerçe filosoflar, içtimaiyatcılar, hukukcular ve iktisadcılar hukuk ile iktisadın münasebetleri hakkında çok konuștular ve çok yazdılar; kimi her iki ilim kolunun birbirine taban tabana zıd olduğunu söyledi; kimi her iki ilmin birbirine ve karşllılı olarak slkı bir surette tabi bulunduğunu iddia eyledi; kimi hukukun iktisaddan ibaret olduğunu iddia eyledi. Hakikat budur $\mathrm{ki}$ her iki ilim, masaldaki kör ve kötürüm gibi birbirlerine muhtaçtır. Fransada millî iktisadı kurmuș olan hocamı Cauwes: Roma hukuku profesörlüğünden iktisad profesörlüğüne geçmiș olan Cauwes "«hukukcu iktisadeı da olmalıdır» der.

Planiol da der ki: «İktisad hukukî bir ilim değildir, fakat kanunlar ile sikı bir münasebet halindedir: Hukukun iktisada muhtac bulun. duğu kadar o da hukuka muhtaçtır. İktisad amelî tatbikten mahrum sirf bir nazariye halinde kalmağa mecbur bulunsa idi öğrenilmesi faidesiz olurdu, boș bir șey olarak kalırdı: İktisad, ancak vardığı ve elde ettiği neticeleri kanun teklifi șeklinde ifade etmek șartile var olması sebebini elde edebilir. Bu sebepten iktisadın hakiki gaysinin servet olmayı insan olduğunu göstererek Ingiliz düșüncelerini tenkit edenler yüz defa haklıdırlar. Diğer taraftan, Kanun koyucusuna hem üzerinde hareket eylediği sahayı hem de kanunlarının, menfaat ve ișlerin oynak aleminde yapacağı kaçınılmaz tesirlerini bildiren iktisadın ve onun anlamlarının 
sșığndan istifade etmeyen kanun koyucusu kör gibi hareket etmiş olur; kararlar da ekseriya meșum sonuçlar verir.

$\mathrm{Bu}$ sebepten hukuk faküleleri iktisad tedrisatının yeridir. Kanunlar ve iktisad ayni problemin (meselenin): içtimaî hayat problemịnin iki yüzüđür. Vaktile iktisad müstakil ve hukukla teması aranılmaksızın tahsil edilirdi; çok kerre mücerretlik bulutları ve nazarî tartıșmalar içinde gayıp olup giderdi. Iktisad tahsilini hukuk tahsiline iștirak ettirdikleri gün iktisada en dikkati çeken hizmeti yapmış oldular. İktisad bizim hukuk fakültelerimize girmekle son gayesi olan kanunlarla temasa girdi; sağlamlaștı ve genișledi. Ayni zamandada hukuk tahsilini canlandırdı. Hukukcuları, kanunların yazılı formüllerinin. (lafizlarının) arkasından hukukun kendileri için yapıldıği canlı gerçekliklẹi görmeğe alıștırdı; ve kanunların faidelerini, iyiliklerini ve kusurlarını iktisadî tesirlerine ve içtimaî neticelerine göre takdir etmeğe alıștırdı. Bugün hukukcunun, iktisacî noktai nazarı gözünden uzak tutarak, kaçırarak izah ede. bileceği bir hukuk meselesi yoktur. Bugün kim, iktisada ehemmiyet vermeden, onun müsahedelerine, belgelerine ve hatta kararsizlıklarina ehemmiyet vermeden toprak mülkiyetirin tarihini ve șekillerini anlatabilir devir ve nakil tarzlarını, parçalanmasını, kiralama ve işleme tarzlarını münakaşa edebilir; menkul ipotekli kredi ile, para ödüncü ile, satıș ile, ticaretle, șirketlerle; mirasla; vasiyetle; bağıșlama ile; karı koca malları idaresi ile ve saire ile meşgul olabilir,.» (Planiol cild. 1 No. 33).

Planiol hukuk tarihini ve iktisadí bilmeyeni hukukcu saymaz; birincisi hukukun doğuș ve olușunu ikincisi hayattaki tesirlerini ve tatbikini öğretir.

Saleilles, Planioldarı daha ileri gider: «Bir hukukî çözüm tarzını tak. dir edebilmek için bütün iktisadî olayları bihmek lâzımdır.» der. Saleilles'e göre iktisadî veriler yürürlükte olan kanunlarm yalnız vücude getirilmelerini sevk ve idare eylemez «hukukî tefsirin de canlı bir ilham kaynağını teșkil eder». Hülâsa yürürlükte olan karưunların vücude gelmelerinde kanun koyucusunu, tefsirinde yargıçı sevk ve idare eđen iktisadî mutalardır;

Profesör Nast «yargıç, hükmünü dikte edecek kaideyi bizzat olaylardan, iktisadî gerçekliklerden çıkartacaktır» der. Yine Saleilles «uzun zamandanberi yargıç, iktisadî zaruretlerin bertaraf edilemeyen kanunlarindan müteessir olduğu halde bunu meydana vurmağa cesaret edemez.» der. Yine Saleilles «Metinlerin ḋıșında duran bir istikamet işareti, metinlerde tatbikedilmiș șekli bir mantıkın altında saklanmaktadır» der. 
3 - Hukukun tekevvülünde, vücude gelmesinde iktisadî mutaların tesiri itifakla kabul edilmekte olduğu halde iktisad ile hukuk arasındaki farkı tayinde fikirler çatıșmaktadır. Uzun zaman hukuk ile iktisad birbirile karıștırılmıștır: hem felsefe sahasında hem de içtimaî nizamda birbirile karıștırılmıștır.

Adam Smidt'in Glasow'de okuttuğu ders hukukî bi ders idi: Ingiliz mahkemelerinin hukuk yaratan içtihatlarına ait bir ders idi; ve onun meșhur olan «milletlerin servetlerinin sebebleri ve mahiyeti hakkında» ki dersleri hukuka ait derslerinin bir sentezi idi. Çünkü Adam Smidt'in gayesi iktisadî mutaların kanunlar ve kazaî kararlar üzerindeki tesir ve nufuzunu meydana çlkartmaktı: "geçime mülkiyetin arttırılmasına ait sanatların kanunlar, ve hükûmetler üzerinde âmil bulunmalarının derecesini ve bu sanatların kendileri için ihtiyaç duydukları değișmelere benzer değişmeleri kanunlarda ve hükûmetlerde vücude getirdiklerini araștırıyordu» (Roscher, principes d'l'economie politique; Préface).

XVII asır sonlarında Locke, XVIII inci asirda fisyokratlar hukuku da iktisadı da aynı içtimaî nizam anlayıșına istinat ettiriyorlardı.

Buna mukabil iktisad ile hukuku birbirine tamamile yabancı iki ilim kolu olarak telakki edenler vardır. Joserand, «medenî hukuk dersleri» adlı eserinde (Sirey 1930 t. I. No. 7) bu görüșü çok sathi bulduğunu söyler. Hukukun iktisaddan akla göre doğru olmayan ayrllığı amelî bakımdan da tehlikelidir; çünkü hukukî kaidelere mücerret ve sun'î bir karakter izafe etmeğe varır der.

Hukukî olayların iktisadî olaylardan ayrı bulunduğu kabul edildiği takdirde bunların birleștikleri ve ayrıldıkları noktaları meydana çıkartmak lâzımgelir.

Her iki olayda mahiyet birliği ve saha birliği vardır.

Her iki olay daiçtimaî olaylardır; çünkü gelenege dayanir (ananevidir) ve mecburidir. Mecburi tabirini ferd için borçtur manasinda kullanıyorum. Bir olayın içtimaî olduğunu bildiren ve belirten bu iki farikayı izah etmeği faideli bulurum.

1. - İçtimaî fiil asla orijinal (aslî) bir fiil değildir, hiç yapılmamıș bir fiil değildir. Her içtimaî fïl tekraranan, tekrarlanmış olan bir fiildir. İçtimaî fiil tek bir adam. tarafından dahi yapılmıș olsa yine de bu tek adam o fiili icad etmemiștir, o fiili yapılmış olarak muhitinde bulmuștur; demek ki o fiili başka insanlardan almıștır ve o fiili yaparken daha evvel konmuș ve' yapanın hareketlerinin serbestisini muhtelif derecede skkan bir kaideye uymaktadır. Binaenaleyh bir ferdin icadı olan bir fiil değildir. Bir insanın icadı olan bir fiil ancak başka insanlar tarafından 
tekrarlanmıs olmakla bir içtimaî fiil olur. Bu sebepten içtimaî fiiller ferdî fiiller olmayıp genel fiillerdir; bir çok ferdlere müșterek bulunan fiillerdir. O fiiller mutlaka toplu bir halde, grup halinde yapılmaz, fakat mutlaka bir topluluk içinde bir gurup içinde yapılır. Bir sözleșme bir dini ayin, bașka sözleșmeleri ve bașka ayinleri tekrar eylemeleri dolayısile içtimaî fiillerdir.

Fakat her tekrarıanan fïıl mutlaka içtimâ̂ bir fiil değildir. İç gudümleri (sevki tabii) alışkanlık; soya çekmeleri ( $\mathrm{k}$ buna șimdi irsi hialler diyoruz) içtimâ̂ fiil teșkil etmeyen tekrarlamalara vücud verir. Binaenaleyh içtimai fiiller tekrarlanan fiillerin özel bir nevidir. Içtimai fiiller, «ananevi» dirler demek suretile ifade edilen bir tekrarlama tarzını icapettirir. Bu özel tekrarlama tarzı üç karakter arzeder:

a) İçtimai fiiller ayni insan tarafından tekrar edilmez; alıșkanlığın vücuda getirdiği fiiller ise ayni insan tarafından tekrarlanır. «Tarde» içtimaî fiillerin bu karakterini «taklid edilen» sözü ile ifade eder. İçti. mai tekrarlama «intikal éden», «geçen» denilen tekrarlamaların içine giren bir nevidir.

b) İçtimai fiillerin tekrarlanması tarzı kendisi gibi, intikal etmiş fiiller nevinden olan iç güdümün vücuảe getırdiği fiillerden, hususile soya çekmekten gelen fiillerin tekrarlanması tarzlarından büsbütün bașkadır. Soydan gelen tekrarların ferd üzerindeki baskıları doğrudan doğruya olmaz, vasitalı olur, yani ferde fiillerini; ferdin fizik bünyesi vasitasile yaptırır; ferdin vucudü üzerinde komuta ederek ve baskı yaparak yaptırır. Halbuki içtimaî kaidelerin baskısı doğrudan doğruya olur. İ'sî haller biyolojinin (hayatın) bir zaruretidir; İçtimaî haller cemiyetin bir emridir. Insan doğar iken irsî modellerini yapılmıs olarak bulur, ve bu modellere mihanikî bir tarzđa ve dıșarıdan bir müsebbib olmaksızm yani sebeb olan bulunmaksızin kendiliğinden intibak eyler (uyar). Hal. buki hukukí kaideler, ahlakî adetler ve dini ișlel ferde cemiyet tarafından ve bünyesi dıșından doğrudan doğruya yükletilir (teklif edilir); ferdin, cemiyetin kendisine yüklediği bu kaidelere uyabilmesi için uzun bir terbiyeye (egitime) ihtiyaç gözükür. Cemiyet çraklığını, öğrenciliğini icabettirir; müșterek geçecek hayat öğrenilmezse cemiyet vücude gelemez. Çünkü içtimaî istimaller (pratik) ancak cemiyet içinde anlaşılabilir ve ancak cemiyet vasıtasile anlaşılabilir; içtimaî istimaller ferdin mahiyetini ifade etmeyip cemiyetin mahiyetini bildirmesi itibarile ferd o istimalleri dıșarıda bir müsebbible, bir gösterici olmaksızın kendiliğinden bulamaz. 


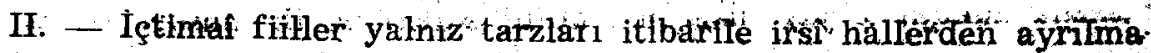

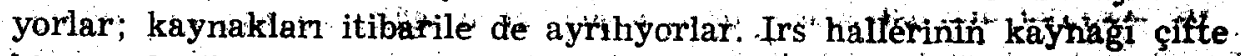

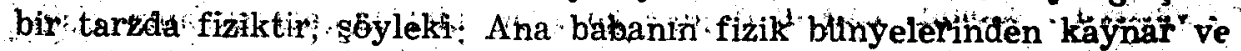

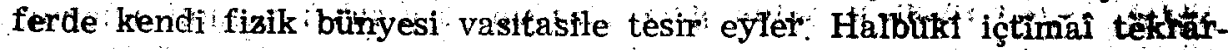

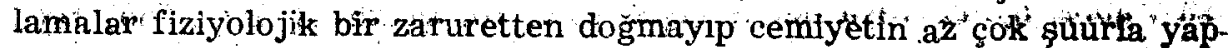

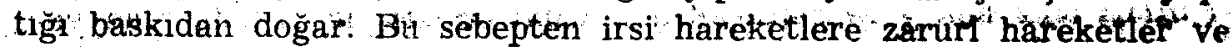

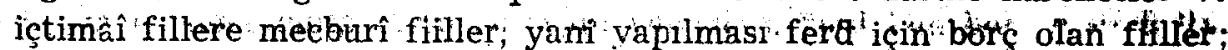

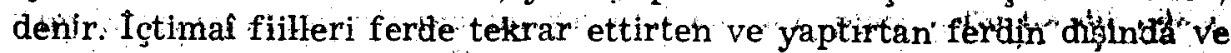
üstünde duran guruptur. Bîrinin zarurî diğerinin! lugat "manásilể bơrç"ot-

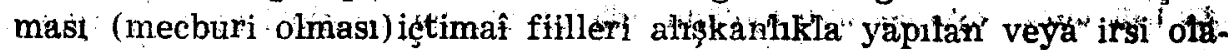

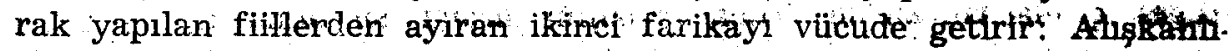
ğtn veya soya çekmenin yaptırdiğ fillter ferddén ferde geçer, binathaleyh

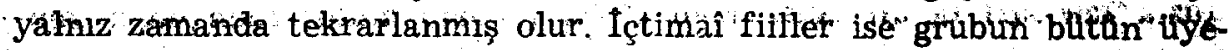
lerine ayn zamanda yükletilmis oldugundan hem zdmanda ve heth de mekân da tekrarlanir.

Demek ki bir fillín içtimal olması için kolektif olmasl, yant grub

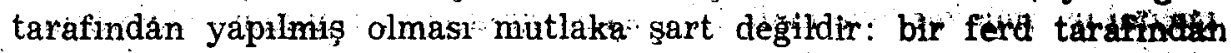

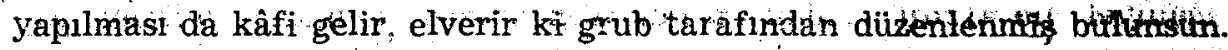
Bu izahlardan çikan tarife göre «içtimaî fiiller bir gtto; b\# centyet tárafindan yapilan veya dogrudan-dogrnya tanzim edilén artatevi ve mecburî fiillerdir» (R. Maunier, Hukuk ve iktisad saf: 12). Bu uztn paräntesı kapatarak tékrar başladığımz yere gelelim:

Íktisadî olaylarla hukukî olaylar arasinda evvélâ makiyet birtfót ve sonra da saha birliği vardır.

Her iki olayın ananevî ve mecburi bulunmalarindân ötürì içtíñầ olay olmalari onlar arasında bir mahiyet birliği vücude getírír.

Her iki olay arasında bir saha birliği de vardır; çünkü hukukì kaide de iktisadî kaide gibi ihtiyaçların tatminini, yerine getírilmesini ve ferdî veya Rolektif (müssterek) menfaatların korunmasın icabettiren vàziyetleri düzenler.

Yalnız iktisadî olaylar ile hukukî olaylar arasinda derece farkı várdir șöyleki: her ekonomik kaide bilkuvve hukukî kaidedir. Fakat hukukî kaide, karakterinin ve hudutlarinin " derecesile" iktisàdr kâdeler aşar

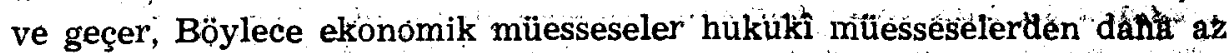

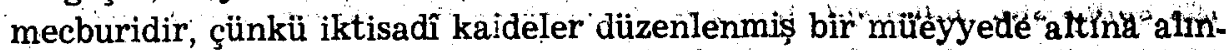

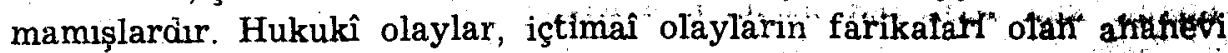

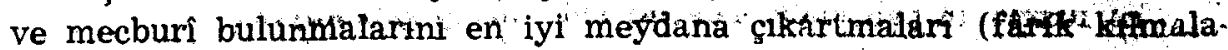

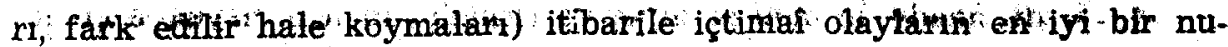

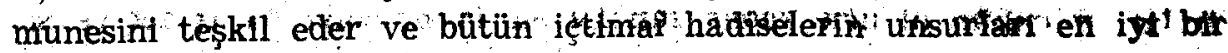


tarzda hukuki olaylar üzerinde tahlil edilebilir. Bu unsurlar suje, obje ve müleyyededen ibarettir. Hukuk sujeye göre değişir, çünkü sujelérin ehliyetlerine tabidir. Hukuk objeye göre değişir; meselâ eşyanın cisimli (ayin) veya cisimsiz olmasına göre; menkul veya gayri menkul bulunmasina göre; aynile veya nevile (B.K. Mad. 70; ticaret K. Mar. 660) tayin edilmiş olmasina göre mülkiyetin tanzimi de değişir. Hukuk müeyyedeye göre de değişir; müeyyede medenî olur, cezaî olur; iade ve tazmin olur; tenkil olur. Diğer içtimaî olaýları hukukî olaylardan ayıran farkları suje, obje ve müeyyedenin hal ve șartları vücude getirir. Hukukun medenî veya cezaiye aymilmasina nasıl müeyyedeleri sebep oluyorsa diğer içtimai fiilleri de içtimaî baskının tarzları șınflandırır.

Hukukî kaideler iktisadî kaidelerden daha fazla ananevi ve daha fazla mecburî bulunduklarından ötürü iktisadî kaidelerden daha geniş oldukları gibi yalnız ahlâktan müteessir oldukları yerlerde de iktisadî kaidelerden daha fazla genișlik gösterir denebilir mi?

Ahlaki olay, efkârı umumiyenin onu fena görmesi suretile açık olmayan bir müeyyedeye maliktir. Demek ki ahlâk hukuktan müeyyedenin mahiyeti ile aymlır. Ahlâk ile hukukun objeleri aynıdır: vermek, yapmak, yapmamaktir.

Hukukí ve iktisadî olaylar aynı mahiyette olunca ve bunların birbiri üzerindeki tesirleri de kabul edilince hukuki olaylardan yalnız müeyyede tarzı ile ayrılan ahlakın hukuk ile doğrudan doğruya tesiri kabul edileceği gibi iktisad ile de münasebetlerini kabul mecburiyeti vardır.

Fakat Demogue ahlak kaidesine kuvvetin ifaze edilmesinin (bağlanmasının) faideden başka bir sebebi olamıyacağını ileri sürer. Hukukî gelişmeye rehberlik edecek bị hakkın zaruretini iddia ederken, Demogue o hakkı ahalkın uyruku kılmaği da reddeyler ve belki aksinin, tersinin doğru olabilẹreğini ileri sürer: «ahlâk eger hususî mülkiyete saygi göstérilmesini emrediyor ve bu saygının gösterilmesini sağlamak, için kuvveti katıyorsa sebebi iktisadın hususî mülkiyet müessesesini meşru görmesi ve netice itibarile diğer teșkilâttan daha yüksek tucması ve bulmasıdır.» (Demogue, borçlar hukuku cld II).

4. - Geny ilim ile teknik yani veri (muta) ile inşa) (yapım çizim) arasında bir fark teklif ederken hukukun sirf teknik olarak vücude getirilebilmesini imkânsız görüyor ve binaenaleyh çeşitli fikrî usullerle hukukî kaidelerin temellerini araștırıyor.

Hukukcunun çalışmalarında iki ayrı kutup gözüküyor:

1. - Mự̧ahade. İçtimaî mahiyet ve ictimaî tabiatın meydana çıarttukları mümkün olduğu kadar sun'ilikten (yapmaciktan) temiz ve saf 
olarak müşahede olunmalıdır. Veri (muta) içtimaî tabiatın izhar eylediği șeydir.

2. - Verinin hukukî nizamın ihtiyaçlamna intibak ettirilmesi yani uydurulması. Bu uydurma işlevi tamamile subjektif bir haldir. Işlenmemiş ve yontulmamış bị halởe bulunan veri hukukî nizama intibak ameliyesi ile cemiyet içinde yaşayan insanlarin münasebetlerini tanzime hazır bir inşa haline girer (Geny; positif (mevzu) hususî hukukta flím ve teknik. I inci kisim Sah. 97).

Ortolon, bundan bir asir evvel Paris hukuk fakültesinde verdiği Roma hukukú derslerinde hukukî fiillerden bahsederken derki: «Işte hu. kukcunun yüksek vazifesi; hukukcu hülyaların veya nazariyenin müphemiyeti içinde yaşayan kimse değildir. Hukukcu olaylar alemine dal. mış bir kimsedir. Insanların yaptıklarına olduğu kadar tabiatın olıyla. rına da dalmış; ferdi sahaların olaylamna olduğu kadar buiyiik amme sahalamnın olaylarına da dalmış kimsedir. Kötü veya iyi ihtiraslann yarattığı olaylar, bütün olaylar onun konusudur. Fiil denilen bu maddr unsurlardan fikrî ve zihnî netice olan hukuku bulur çıkartır. Iyi ve nefasetli olan hukuku bulur ve bulduğu hukuk fiillere kaide teşkil eder ve fiillere emreyler» (Legislation Romaine, histoire et generalisation sah. 619 No. 149):

$\mathrm{Bu}$ uzun sürmüș giriși burada keserek evvelâ hukuk ile ahlakın ve sonra da hukuk ile iktisadın münasebetlerini tetkik edelim:

\section{II}

Hukuk ile ahlâkan münasebeti.

5. - Roma hukuk aleminin unsurları oportunligin (1) soluk ve ülküden mahrum sahasında gözükmekle hayæta doğdu. Bunlar pratik ga. yeler güden ve bu itibarla muhakkak kıymeti olan fakat ahlakî yükseklikten de mahrum bulunan fikir ve müesseselerden ibaretti. Hiç bir dev let ve hiç bir hukuk bu gibi malzemelerle inşa edilemez. "Bir milletin kendi içinden bulup çıkardığı kendine benzer; ellerile dokunmağa cesaret eylediği solar ve bozulur. Insan ancak ulasamadığı șeyi kutlu bulur ve mukadeds olarak sayar.» (Jacques Crimm)

Hukuk her yerde, tarihe ilk olarak girerken allahın refakatinde olarak girer. Bu büyük tavsiye onu menfaatlarm, oportunligin; islamiyetin

(1) Oportunligin en iyi ve en belig. sekilde su ata sözü anlatır: slyiki geldin koca älüyordum bu geçe.s 
Seytan adını verdiği aklın tenkitlerinin ve yalın kuvvetin keyfi hareket. lerinin vücude getirecekleri inkilaplardan .korur ve hukuku insanlar tarafindan kesilemeyen (yürülüp bitirilemiyen) yollaria uzaklaştırılmış bir âleme yerlestitirmek suretile ona saygı sağlanır. Hukukun emirleri allahın emirleri kllınır. Bu emirlerden özel bir ahlakî önemi ve ağırlığı taşıyanlar münferit bir ilahî emir kılınır, değilse topu birden ilahî emir kalinir.

Bu hadisede bir hesap, bir kast ve bir hile (kurnazlik) aramak hata olur. Hukukun ahlakî bir mahiyeti haiz bulunduğu duygusu dinî bir tabiat ile yaratılmış kimselere bu ahlakî emirleri, Hakkın (allahın) sesi olarak subjektif bir tarzda ahz ve telakkiye ve aynı zamanda görüșlerini ve ilhamlarmı allahin bildirmesi (vahi) șeklinde halka yükletilmesine imkân verir. Dinî duyguları fazla ayakta olan (1) Doğu halkı hakkın (allahın) sesini hukukun münasebetlerinde ve emirlerinde ve ahlakın emirlerinde her tarafta işitir ve keşfeder. Hukukun, ahlakın ve dinin sahalarında bağımsızlık yoktur; ahlakın iradesi fikri bunların hepsini aynı hizaya aynı çizgiye getirir (Thering, Roma hukukunun ruhu, cild I No. 21)

Romada ahlâk, cumhuriyet devrinin sonlarında ve Yunanistanın fethinden sonra dinden ayrlimağa başladı ve sırf felsefi bir hale geldi. Yunan felsefesi, aydın kimseler arasında yayılmağa bassladıktan sonra ahlâk ile kanun arasındaki münasebet Roma hukukcularını dikkat nazarını çekti. Romalılar, amelî olan tabiatları icabı Yunanın muhtelif mekteplerinden fikirler topladılar ve o toplama fikirlerle umumî menfaatı korumağa matuf bir doktrin vücude getirdiler. Romallarin ahlak ile hukukun münasebetlerine ait olan bu doktrinleri şu iki kaziyede toplanır:

1. - Hic bir positif (mevzu) hukuk mutlak bir ahlak ile tamamile uygun düșemez, çünkü hukukun inșasında faidenin önemli rolü vardır ve bu rolü, ahlâkî endișeler bertaraf edemez.

- 2. - Positif hukuk ic̣timaî faidenin imkân verdiği derecede ahlaka yaklaşmalıdır: Kanunlar yapllırken yaklaşmalıdır; kanulnar tefsir edilir ve boșlukları doldurulur iken, nâsafeti kullanmak suretile yaklaşmahdur.

Pirincipat devrinde yunan felsefesi fikirler üzerinde tesirini göstermekten ve onlar kendine çekmekten el çekmedi ve en büyük tesirini hukukun mevzuunu (konusunu) tayinde gösterdi, hukukî kaideler ahlakî

... (I.) Fazla tahrik halini (surexcitation), Türkşede avaklanmak sözü ile ifade ederler misal: eSinirlerin ayaklands 
kaideler olarak gösterildi: «Hukukun emirleri şunlardir: namuslu yåsamak, kimseye zarar vermemek ve her kese kendisine ait olanı vermeks.

6. - Faide kavramı hukukun, adalet ülküsüne göre olan görevini ifade etmeyip onun içtimaî hayatın zaruretlerine göre yüklenmiş olduğu görevleri ifade eder. Demek ki hukukun bir görevi adalet ülküsünü gerçekleştirmektir. Diğer görevi içtimaî hayatın zaruretlerini cevaplandırmaktır. İslâm hukuku, hukukun içtimaì hayatın zaruretleri dolayısile adalet ülküsünden aynlıp koyduğu kaideleri «istihsan suretile» konmuş olarak kabul eder. İstihsan begenmek ve makbul tutmak demektir; içtimaî hayatin zaruretlerini mecelle sadece «zaruret» «hacet» kelimelerile ifade eder. «Zaruretler yasak olan şeyi caiz kılar» sözü adalet ülküisünden ayrilma derecesini gösterir. «Zarurî olan bir işi elde etmek için bir kötïlük (mefsedet) iltizam kılınır ise o kötülük kötülükten çikar; zaruret sebebile meydana gelen şeyler yalnı zaruret ölçüsünün gösterdiği dore cede kabul oḷnur».

Umumî ihtiyaçı defetmek umumî bir iyilik olur; kanun halka «er: fak» olacaktır (halka tatl ve yumuşak olacaktır). Istihsan hukukun, halin zaruretlerine uygunluğu ve dar mantıktan aymlışıdır. Gaỉus III. 150: «Vekâlet daha ifa edilmeden evvel tarafların biri ölür ise, gerek vekâleti veren gerekse vekil ölmüş ise vekâlet sona erer. Fakat faideyè dayanan bir sebeb bana vekâleti veren kimsnin ölümünden sonra; ölmüş olduğunu bilmeksizin vekâleti ifa etmiş isem vekâlet davasıni açabilirim. Aksi takdirde meşru ve makul bir cihalet bana zarar verir. Yine böyle bir sebep dolayısile vereceklim hata ederek kâhyama onu azat etmemden sonra vereceğini verir ise vereceğinden kurtulur. Halbuki hukukun (strict) dar prensipleri mucibince vereceğinden kurtulmaması lâzımgelirdi, çînkü vereceği; vermesi lâzımgelen şahıstan bașka bir șahıșa vermiștir.»

«Hukuk en geniş manasile iyi ve adil olan şeydir; yani tabii hukuk dar manasile bir memleket halkına faideli olan șeydir, yani medenî hukuktur» (Digesta I.I.III.)

Bugiinde faide kavramını hukuka rehber olarak kabul etmek isteyenler var. Tabii hukuku, hukuka inehberlik edecek en büyük prensib olarak kabul edenler dahi faidenin hukukun bazı kaidelerine hakim olabileceğini kabul ediyorlar. Meselâ Edmond Picard «Hukuka, yalinż hał olan kabul edilecek olsa idi hukukun ideoloji sarayınin bir zaman gelip hemen hemen boş kalmasından korkulur idi der.» (Picard; les consitan... tes du droit sah. 120).

Faideyi hukukun olușuna hakim krlmak isteyen Vander - Eycken de, hrikukun tefsirinde positif metod adl eserinde (sah. 248 No. 133). 
\$bukuku faide yerine adaletle; hakla izaha kalkmak màntıkî telâkkilere bagll kalmak olur. Hak ikinci derecede bir kavramdir, bir neticedir: Faidenin ilham eylediği çözümlerin kabul ve teydidir.» der. Binaenaleyh gerek kanun koyucusuna, kanunu yaratırken gerek yargıça kanunu tefsir ederken yalnız faide rehberlik edebilir. Böylece faide mevzu hukukun esasil mutası oluyor.

7. - Faideyi bir tarafa burakarak hukukun vücude gelmesinde âmil olan ahlakî mutaiarı araştıracak olur isek bir çok kaviamlar ile karşı karşıya geliriz. Hukuka daima bir rehber arayan hukukcularm, ahlâkî mutaları daima bir kelime veya iki üç kelimelik bir tabir içine sıkıştırmıs olduklarını görürüz. Bu rehber fikir zamannnżda «insan hürriyetine saygı, «ahlâkî ödev», «tesanüd»; «adalet» kelimelerile ifade olunmaktadur. Fakat biitiun bu kavramlarmn «tabii hukuk» kavramina irca edileceğini çünkü tabii hukukun positif hukuka esaslı direktiflerini verecek yưksek mutaların varlığını kabulden ibaret bulunduğunu jleri sürenler vardur. Tek ve mutlak bir prensipten tezatlarla dolu olan içtimaî hayata hakim olacak kaideleri akıl vasitasile bulmak ve çikrtmak hayat ile ilgisi olmayan nazarî bir inşada bulunmak olacağını iddia edenler vardır. Adalet denilen müşterek kavramın çeşitli şekilde gözükebilmesine kalıp teşkil eden bütün ahlakî kaideleri tek bir mücerret mefhumdan çıkartmăga çalıșmak boș bir emektir. Bu emeği sarf eden eskilerin de yenilerin de elleri bögüurlerinde kaldı ve baska bir netice hasıl olmadı diyenler var.

Fakat bütün bu șüphe ve tereddütlere rağmen insan vicdanının en mahrem, en gizli ve en derin kavramlarından durmadan yüksek ahlakî mutalar fişkurmakta olduğu da bir hakikattir. Ciceron hulkuk kaidelerinin, en harim (dokunulmaz ve muhafaza edilmesi vacib) felsefede: «ex intima philosophia» da araması lâzım geldiğini söyler.

XIX uncu asır başlarının en büyük medeniyetcilerinden olan ve çok biiyük bir hukukcu bulunan fransız «Toullier» nin Cicero'nun bu sözlerinin mezar taşına yazılmasını vasiyet etmiș olduğunu söylersek Ciceron, bu sözleri ile bütün hukukcuların vicdanlarmı ve kanaatlerini ifade eylemiş olduğunu hakkile iddia edebiliriz.

Burada hukukun doğuşundan beri; hukuka rehberlik etmiş fikirlerden yalnız üçünï arz edeceğim: clalet (justitia); Nasafet (aequitas); tabii hukuk. Bu üç büyük kavrama yalnı Ripert'in son zamanda gelip kattığı medenî borçlarda «ahlâls kaidesi» ni ekliyeceğim.

8. - Adalet (justitia) - Ulpianus'un, Diegesta da ve Justinianusun inotitutes'lerinde yer bulmuş ve onların ilk cümleleri kllnmış meshur 
"tarifine göre «adalet her kese hakkını vermek hususunda kesin ve ardı kesilmez bir iradedir.» Iradenin kesin olması . o iradeye karşi koyulduğu zaman irade yenilemiyecektir; o irade harekete geçtiği zaman ona karşı konulamıacaktır.

Iradenin ardı kesilmez olması, devamlı olması demek olmayıp daimî olması demektir; yani insan hayatı var oldukça var olacak dëmektir. Türk halkı, kötü duasında «allah hakkını versin» demez; «mustahakk1nı» versin der; demek ki adalet türk dilinde «her kese mustahakını: mustahak olduğu şeyi vermektir,» diye ifade olunuyor.

Ciceron, Ulpianusur tarifini başka kelimelerle ifade etmiştír. Iki tarif arasındaki fark değiştirilmiş iki kelimededir. Ciceron «irade» (voluntas) tabirini kullanmaz, yerine «habitus animi» der ve böylece 'bize iradeyi de anlatmış olur. Stoa mektebinin (istoysiyen, revakıyon) felsefesini hukuka hakim kılan. Cicerona göre adalet hem fikrin, zihnin bir tasavvurudur bir anlayışıdır, bir telâkkisidir ve bu itibarla da zeka ve aklın semeresidir; hem de bir iradedir yani kudret halinde bir hareket ve ameldir (iştir).

Ciceron hak (jus) kelimesini de kullanmaz ve «hakkını. (jus suum) «mustahak olduğunu» demez; yerine «Dignitas» kelimesini kullanı. Dignitas kelimesini anlatmak çin insan hakkında verilmiş vasuflar hatịrlamak kâfidir: yaratılmışların en şereflisi (eșref-i mahlukat); «biz adem oğulların muhakkak ki serefli ve izzetli kıldık» (kuran ayeti) Türk halk1 Dignitas'1 «layık olunan şey» diye de tercume ve ifade eyler: «Allah layikini versin!». Demek ki «her kese hakkını vermek» Ciceron'a göre «her kese, ailede ve cemiyette ki kadr-ü kıymetine (göre iktidạr ve kıymetine) göre hakkı olanı vermek» demek olur. Türk dilinde her kese hakkını vermek layık olduğu şeyi vermektir.

Mücerret bir tasavvur olan adalet, Ciceron'un düşüncelerini ifade eylediği Romalılara göre hisse (duyguya) dayanmayıp akla ve iradeye dayanir.

Ve yine Ciceron'a göre adaletin üstünde duran bir șey var; ȩünkü adil olmak her kese payını ona layık olanı vermektir. Her kesin adaletin vermesi lâzımgelen payı nedir?

Her kesin lâyıkı nedir? Adalet endişesi kendilerini, inkisarlarında (kırgınlıklarında). dahi terk etmeyen Türk milletinin ağzından eksik olmayan bu «dïssen pay» «muistahak olunan (hak edilen) 》layik olunan» şey nedir? Bu vesile ile paylamak kelimesinin adalet tevzii manasına geldiğini sanmak doğru olur: "agzının payını verdim» tabirinde oldüğ gibi. Aslı sanskiritceye kadar çıktığı iddia edilen «paj» veya dilimizadeki 
Sellile «pay» hissse manasına olarą Osmanlıcaya yeni girmiștir ve eski metinlerde yoktur. Hișșeye eski metinler ülüs der; paylaşmak üleşmektir hükümdarların topkaklai' ogulları azasłnda ülüşmesinden «ülke» kelimesi doğmuștur.

Her kesin hakkı olan seyi cemiyetin mahiyeti tayineder; ödevleri yaratgn tabiat ve ahlak tayineder. Tabiat insanlar arasinda münasebetler kurmustur. Bugünkü tabirle medeniyet veya eski tabirle hayat yahut Ciceron'un dili ile ödevler (de offici) bu münasebetleri kuvvetleștiriyor ve insarlar arasında esitsizlikler (müsavatsizliklar) yaratiyor. Bu müsayatsıluk bazl kimselere baskalarından karşlıksız olarak bir şey istemeğe imkân veriyor yani başkalar, kendilerinder bir şey iṣteyebilen kimselerden ona karşı yaptıklarının karşılığını ondan isteyemeyorlar. ,Din; atalar łuhuna ibadet; aile reisine olan saygı; yaplmıs hizmetlere karşı borçlanılan minnet; istihkak davası ve mülkiyetin masuniyeti insanlar arasında ödevlerin yarattı̆ğ münasebetlerdir.

Bu münasebetlere yani bu müsavatsıliklara eşit derecede riayete bir ad bulmak ve vermek lâzımdır. Bu eşits'zlikte eşitliliği yani bu müsavatsızılı̆a riayette müsavatı ifade ejecek bir kelime bulmak lâzımdır. Insanlar arasındaki orantayı (nisbeti, tenasiubü) emniyetle tayin edecek bir ince alet bulmak lâzımdır. Nisbî eşitjil'ği belirtecek bir kavram lâzimdir. Bu aranlan kavrama nasafet veya insaf dendi.

9. - Nasafet, eski çăg cemiyetlerinde, insanları ölçen bir vahid-i kiyasi olarak gözükür. Insanler arasındaki orantalı eşitliği meydana vuran ve o orantay hesablamağa imkân veren bir ölçüdür: Nasafet, Romada hukuku: «iyr ve insafli olan seyin sanatıdır» șeklinde tarife sevkeden ve imkân veren bir kavramür. Iyi ve insaflı tabiri Romada adalet duygusu tabiri manasına olduğundan Nașafet adalẹt duygusudur șeklinde tarif lunabilir. Assım - efendi merhumun meşhur olan Kamus tercümesinde nasafetle adalet ayni manalarda olarak gösterilir.

Nasafet kelimesinin kökü «nısıf» tır ki yarilamak, yarım yarım kılmak manasinadir. Astm efendi Nasafet'in adil manasına geldiğini anlațkkken «bu dahi nısıf manasından alınmıștur. Zira âdil tesviyeyi (ki düz kulmak, ayni boya getirmek demektir mutazammindır; meselâ muamelede-adalet bir kimsenin menfaat gördüğü adama en azdan misli miktarında menfaat vermekten, kezalik mazarrat gördüğu adama gördüğü mazarrat kedar zarar vermekten ibarettir. Hizmet hususunda dahi böyledir. Bir zdamın kendisinden hayır ve nimet gördüğï kimseye o kadarcık hizmet ve islerinde himmet eylemek (yani bir işin yapılması için çalışmak) tesvivo mutazgmmindur.» «-BBaba himmet! - oğlum hizmet!» diyen ata sö- 


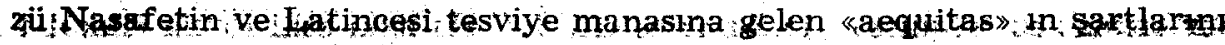
tayin ediyor. Asmm efendi adaleti de «bir nesneyi bir nesne jle bepaberleştirmek ve mahfede bir adama denk olmak; bir nesne mukabilinde ceza ve ivaz manasina kullanilir» der. Yine Astm efendi Hak kelimesinin Adil. manasına geldiğini söyler. Terazi bir nesneyi beraberleştirmenin aleti ve adaletin timsalidir. Deve ile arabada olduğu gibi rahat bir yer yạpt1rarak giden kimseler devenin birer tarafina binerler; bindikleri yere mahfe denir. Mahfede, tıpłı bir hayvana yükletilen yük gibi denk gelmek lâzımdir ve bu denk gelmeye de adalet dendiğini yukarida Așım efendiden naklen sëyledim. (Bu meseller hak. Ankara Hukuk Fakiultesi 1941-1942 yıllığinda yazdığım ölçek makalesine bakınız sah. ,73).

Aequitas Stoa mektebi için bütün insanlarin boyunụ ölçen bir ölçüdür; bütün insanlarin arasındaki nisbeti gösteren ölçüdüir.

Halbuki Aristotalis'e göre Nasafet daha mütevaż bir kavramdir; hak kaidesinin zıddı olan bir kavramdır. «Nasafet yazilı olan hak kaidesi dișinda duran haktur.»

Yine Aristotalis Nasafeti su tarzda da tarif eyleyor: «Kanunun doğru bìr düzeltilmesidir»; "kaideye elifi elifine uygun bir doğrunun, doğ ru bir düzeltilmesidir.» Hülâsa nasafet Aristotalis'e göre daha iyi bir adalettir. Nasafetsiz bir hak Ciceron'un ağzinda ve kaleminde «en bijyiik adalet en büyilk-adatetsizliktír» (Summum jus, summa injuria) cümlesile ifade olunmuştur. Yani Elifi elifine tatbik edilen, yalnız lafzile tatbi kedilen bir hukuk kaidesi yargıcı haksıziığa sevkeder. Binaenaleyh buna mani olmak için yargıçin bir düzeltme yapabilmesi lâzımdir. Yapılabilecek olan o düzeltmeye Nàsafet denir. Bu hakikatı daha iyi anlamak için Thering'in Roma hukukunun ruhu adlı eserinde yazll (No. 33) aşağıdaki satirları okumak lấzimdır: "Ḳ̣anun önünde eşitlik adalet fikrinin bir tecellisidir: mahiyeti itibarile eșit olan eşit bir muameleye mazhar olmalıdır. Her șeyi derpiș etmesine imkân olmayan bir kanunun, tabirlerindeki umumilik dolayısile; kanunî adalet münferit bir hadisede hakslz neticelere varırsa nasafet imdada yetișir ve haksızhğ düzeltir. Násafet hakimi kanunu lafizlarındaki şiddetle tatbik eylemez. Kanun koyucusu Hâdis olan (meydana çıan) münferid hadiseyi derpiş edebilmis olsa iủi kanunu nasıl tatbik edecek idise nasafet yargıci da öyle tatbik eder.

Fakat eșitlik nedir? Eski Roma hukuku, yeni modern hukuk kadar eșitliği (aequum jus, aequitaś) koymağa uğraștı. Fakat eşitliğin yeni modern hukukdaki manasile eski hukuktaki manasi arasındaki bir uçurum vardır. Tacite XII lava kanunununa «hukukun en azami müsavat haddi» 


\section{der «finis aequni juris» (1). Annales III, 27). Halbuki eski Roma Hukuku}

nu takibeden sonraki hukuk ta müsavatı kendisinin yaratmiş olmak iddiasinı kendisine hasreyledi; ve eski dar hukukun (strictum jus) zıddi olarak; nasafetli bir hak olarak gözüktü. Sonraki zamanların; eski Roma hukuku olan bu dar hukuk hakknndaki düşüncesi meșhur olan «Summum jus summa injuria» kaidesinde ifade edilmiştir. Bu kaide eski hukukun; müsavat temayülü yüzünden ardında sonsuz bir müsavatsızlık' sürüklemiş olduğunun acı bir di! ile beyan eder. Halbuki sonraki hukukun anladığ manada nasafet eski devirlere; hakiki bir müsavattan sapma (inhiraf) gibi gözükmüş olaçaktı. Sonraki zamanların jfrata vardırılmış bir iyilikten kaynayan nasafeti kadınlaşacak, belki de gelecek zamanların daha fazla nasafet duygusuna bazen çok şiddetli de gözïkebilir. (Nasafetin nisbî mahiyeti hakkında Thül'ön Alman hususi hukukuna giriş adlı eserinde 18 e bakiniz).

Şimdi bu müsavata ne oldu? Her zamanın hukukta müsavatı tesis etmek hususundaki müstakar (sabit; değișmeyen) temayülüne răgmen elde edilen neticelerde pek fazla hissedilen farklar nereden geliyor? Bunun iki sebebi vardır: Bu'sebeplerden biri maddî diğeri ferdîdir. Evvelâ bizzat her şey zaman esnasında değişmektedir. Halk hayatının servete (zenginliğe), tahsil ve terbiyeye (eyitime), içtimaî mevkie oturduğu yere; tegrifatta evvel gelmek hakkının varlığına veya yokluğuna ve saireye göre vaki münasebetlerinin menşe'deki benzerlikleri yerine bu münasebetler arasinda medeniyetin ilerlemesiyle git gide daha bariz bir ayr. lik husule gelmektedir. Bu husule gelen ayrilığın önünde, münasebetlerịn iptidadaki eşitliği hesap edilerek konmuş eski hükümlerin bırakılması ve tutulmasi git gide imkânsız oluyor, eski hukukun sabit ve müstakar bir tazda konmuş olan 25;500;1000 „as" lık malî hükümleri sonraki devirde mutlak bir imkânsızlik gibi gözülktü. Roma arazisi ve ticaret sahası yüz defa bin defa büyüdügü zaman eski hukukun hazır onlarla hazır olmayanlar arasında gözettiği müsavi muameleyi tutmağa ve yașatmağa imkân kalmadı. Daha sonra her şey geçtikçe fikirler de değișiyor. Müsavatsızlık hissi daha fazla saflașlyor: Halk daha iyi anlayor. Adalet hissi daha fazla müteessir olur hale geliyor. Kaba hukukî hissin güç'ükle görebileceği bir münasebet aydınlasmış bir devrin inceleșmiş hislerine hukukî hüküm üzerinde kesin bir tarzda müessir gözü-

(1) Bu fikri iyi anlamak için islamlarin kuran abelagatin en son haddi olarak gôrmeleri ile mukavese etmek lâzımdır. Kurandan dahạ belị bir sev vücude getirilemive. ceăi gibi plebslerin potricilerle essitlikierini vücuda getirmek için vpalmıs olan XII lavha kanunundan da daha ziyad müsavatı sağlayabilecek bir kanun da tasavvur edilemez. 
kür; hatta fiilen değişmemiș münasebetler hakkında dahi böylełir; misal olarak kusur ve isnat münasebeti gösterilebilir:

Her hukukun müsavat için tákipettiği ve takipetmesi lâzımgeien yol umumilik yoludur: "Kanunun otoritesi kanun koyucusunun fiiline tabi olan bütün insanlara evrensel jir tarzda samildir; zira kanunlar her şahıs için hususi o!arak konmamıștıp; fakat herkes için umumî olarak konmuştur, (Ulpianus): Umumilik sıniflaștırmak ve o sınıflar için kaideler koymak demektir. Fakat umumilik önüne geçilmesi mümkün ol. mayan bir tehlike teşkil eder: Hakikette müsavi olmayanlara müsavi muamele eder. Hukuk bu umumileştirmekte istediği kadar gittikçe daralan çevreler çizsin, istediği kadar hususiliğe doğru kaysın; tehlike olduğu gibi kalmakta devam eder. Umumiliğin nisketen çok genig olması müsavat fikrini bizzat kendisile (muisavat fikrile) ihtilafa (uyuşmazlığa) sürükler, veya bir haksızlık husule getirir; yani hakikatte müsavi olnayanlar müsavi olarak muameie görürler, çünkü müsavatsızlığı yapen hafif fark kanun tarafından nazara a!ınmamistır. Bu hal ekseriya evvelâ münferit bir hadise meydana çlkar ve bilhassa hissedilir olur. Bu münferit halin, ilerisi için yeni bir kaide koymak fırsatını vermiş olduğunu farzeylesek bile; kanun kendi koyduğunu kozduracak bir vasitajan mahrum bulunuyorsa; hükmü ferdileștirmek yolunda kendiliğinden vücut bulan bir düzeltme imkânindan mahrum bulunuyorsa (meydana çıan ve yeni bir hüküm koyulmasına vesile olan münferid hal) eski hükme feda edilmiş olur. Eğer bir hukuk kendisine gaye olạrak; amaç olaraìs aldıği müsavat fikrinin bizzat kendisile ihtilafa düşmesini istemiyorsa: bu zulum (haksızlık) imkânına tahammül edemiyorsa hükümlerinin cüzeltilebilmesi imkânını vermekten başka bir çaresi yoktur. Hukukun tatbiki cessitli tarzlarda olabilir:

Ya hukukî kaide müsbet halin ferdiliğine uyabilecek bir lastikliği evvelden haiz bulunacaktır (misâl: actio injuriarum aestimatoria da cezaların en yükselk ve en aşağı hadlerli) (1) yahut hukukî kaidenin karşısına; bunun tabikatta ki şiddetini bertaraf edecek bașka bir kaide

(1) Iniuriarum fikihta cinayet dive ifade edilmistir. $\mathrm{Bc}$ cinavet mağdurunun, suc senesi içinde XII lavha kanununun kovduğu kısas ve sabit divet verine tazminat jurisi önünde. juri tarafından nasafet dairesinde tesbit edılmis bir pcra cevazı talep edilebilmesine imkân verebilmek için pretor tarafından, Yunan hukukunu takliden konmus davadır. Formülün başına vakıalar yazıldıkłan sorira hükümediłecek pard cezasının en vüksek haddi pretör veva magdur tarafından tesbit olunmuștu. Zararın bu tarzda takdiri dolavısile dava modern müellifler tarafindan «aestimatoria» dive vasiflandirimistir. Davasın haksız açan davacı karsı taraftan istediă para cezcsının 1,10 ne hüküm giverdi. 
koyulmuş olacaktır (mișal: yeni Roma hukukunun eski hale çevirme müessesesi (restitutio in integrum; hafifletici sebebler)

Yahut yargıcin üzerinde bulunacak bir erk hukukun evvelden tayin edilmemiş bir kaideye tabi olmaksızın düzeltilmesile görevlendirilecektir. Bu sonuncu taiz yaşama erkile yargı erkinin bir kombinezonundan ibaret ve özel bir hal için ihdas edilmiş olur; adeta Pretorün ve sonraları da Imparatorun, bugün de hükümdaların yalnız cezaî adalette (af hakkı) kullandık!arı erklerin birlestirilnıesi haline benzer. Fakat bu son tarz çok tehlikelidir. Hukukî takdir, hukukî kaidenin sagladiğ sağlam zeminden ayrilarak kendini şáhsi teessürlerin oynak topraklarına terketmis olur, ki şuurlu veya șuursuz bir tarzda keyfi olmağa varır. Romanm hususi hukukunda, bu ferdileşmeğe doğru vaki temayül ilk defa olarak bu sonucu tarzda gözükmeğe bașladı. Bu taiz eski hukukun ruhu ile tezat teşkil eder ve eski. hukuka girebilecek bir kapı bulamaz. Kanun koyucusu, özel bir hadise hakkinda kanuna istisna yapamaz: bu özel hal için özel bir - kanun koyảmaz. Yargıç (gerek pretör ve gerekse judex) özel bir ha! jçin kanunun üstüne çıamaz. Eski Roma hukukunun bütün sistemi yargıçın şahsi takdirine bir imkân verilmesine maní idi. Nasafet perdesi arkasinda keyfilik vc tarafkirlik harekete geçebilirdi. Eski hukuk kendisini böyle bir tehlikeye maruz birakmaktan ise nasafeti feda eylemeği tercih eylє’diği gibi kendi müsavat anlayışmin kendisini özel bir hadisede sevk edebileceği ihtimalleri de nasafetin doğurabileceği azamî müsavatsılıklara tercih etti. Eski Romalılar bu ihtimalleri bizden başka bir tarzda karșıllyor]ardı. Müsavatın yatıștırılması mümkün clmayan mantıkı, onların üzerinde ağır basıyordu ve onları, müsavatın sonuçlarına istekle katlanmağa sevk ediyordu. Müsavatın magduru olacak kimse, bir kararın mefru: haksızlığından, adaletin; hakkın emri ve icabı bulunduğu düşüncesile tesellisini bulabilirdi. Hukukî duyggularda da kahramanlık kv ealçaklığa yer vardır. (1) Romalılar buiyük gayeleri, bir ferdin ferdi saadeti ugruna feda edebilecek kimselerden değil idiler. Hukukun durmadan gerçekleştirilmesi, her türlï tarafkirliğin ve keyfiliğin

(1) Ėski hale cevirme pretörün bazı hallerde aldı̆̆ı istinî tedbirlerdir. pretör haiz olduğu imperium (emir ve nehietmẹk vetkisil dolayisile medeni . kanunca sahih olan bir hukuki muamelenin neticelerini yok ederdi. Pretör hadiseleri inceledikten sonro, taarruz edilen, itiraza ugrayan hukukî muamelenin nazarı itibare alınmasını nasafete uvgun bulur ve taraflari sanki yapmis olduk'arı muamelevi hic yapmamislar imis gibi onları, muamelenin vapıldığı zamandan evvelki hallerine . iade eyler di. Eski hale çevirmeve, ferdin kanuna karsı korunmasıdır. der isek mübalaga etmemiş olduğumuzu sanıriz.

(2) «Seraitin (hukukun) kestiği parnnak açınaz» sözü by zil)nî halelin dilimizdeki ifodesidir. 
bertaraf edilmesi Romahlarin düşünceleri üzerinde mühìm tesirini gösteriyo ve XII lavha kanunandan evvelki keyfi ve patriarkal adalet keñdilerini düşüncelerine 0 kadar bağlamış bủlunuyor idi ki sistenîn zarưî mazarratlarına kạhramanca tahammü! gösteriyorlardı. '«Kanunlar çabuk terakki eyleyen cemiyetlerde çabuk eskirler. Binaenaleyh bu eskime ya nasafetli bir tefsir ile, ya kanunî faraziyelerle; ya teșrii düzeltmelerle tamir olunur. Romada pretör Roma mevzu hukukunu; Imparator Hadrianus ve meşhur hukukçu Salvius julianus devrine kadar tabii hukuk nazariyesile düzeltmiş ve eksiklerini doldurmuştur. Roma pretörü bir nasafet yargicı idi».

10 - Nasafetin Roma hukuku üzerinde tesiri : Hem hukukun vïcude gelişi ve hem de tefsiri üzerindeki tesirleri.

A. - Nasafetin Roma hukukunun vücude gelişi üzerindeki tesirini tetkik ederken hukukçuların rolleri ile pretör'ün rolünü birbi rinden ayı̣rmak lâzımgelir.

a) Romanin klâsik hukukçulạri bir kaç Yunan ahlâk prensibini Roma hukukunun esasına soktular. Bunlar ahlakî prensipleri daha ziyade Aristotalis'in eserlerinden aldılar, hususile Nikomaka ahlâk adlı eserinden aldılar. Meselâ Roma hukukunun modern tefsircileri, mezkûr hukiukun aşağıda yazılı iki bưyük prensibinin kaynağını Nikomaka ahlakta bu!duklarinı sanıyorlar:

1. - Haksı mal iktisabı,

2. - Subjektif més'uliyet,

b) Pretörün medenî hukukun (jus civile) bozukluklarını düzeltmek hususunda yaptığı bir çok islahatı ona yaptırtan Nasafet düşïncesi olmustur. XII lavha kanununun vasiyetsiz ölụ̈m halinde kabul eylediği mirasclların çok dar bir daireye maksur kilınmış olmalarından doğan nasafete aykırılığ pretörün emirnameleri ile düzeltilmiş olduğunu misal olarak gösterebiliriz; Gaius III üncü kitabında: «18. vasiyetsiz miras hakkında XII lavha kanununun ihtiva eylediği bütün kaideler bundan ibaret idi. Bu hukukun ne kadar dar olduğunu (strictum fuerit) anlamak kolaydır». «25. Fakat bu haksızlıklar (nasafète aykırılıklar, juris iniquitates) pretörün emirnameleri ile (edictọ) düzeltilmiștir» der. Mirascilar dairesini genişletmeğe ve terekenin etrafına daha fazla mirascı toplamağa eski hukukumuz «tevsi-i intikai» der; terekenin intikalini genişletmek demektir.

B. - Hukukçular medenî hukuku sert lefsir etmemek onu «nasa da erfaks bir arzda tefsir edebilmek için kastı aramağa: kanunlarda kanun koyucusunun kasdini; mukavelelerde taraflarin kasdinı aramăgá baş- 
ladılar. Kanunun yalnız lafzile yürümediğini hem de «ruhu» ile yürürlükte olduğunu ilân eden medenî kanunumuzun birinci maddesi ile borçlar hukukunun «bir aktin șekil ve şartlarmı tayinde iki tarafın gerek aldanarak gerek akidden hokiki maksadı gizlemek için kulandıkların tabir!ere ve isimlere bakılmiyarak onların hakiki ve mïsterek maksatlaıını aramak lâzımdır» diyen 18 inci maddesi menșelerini bu araştırmalarda buldular.

Hukukun ahlaki gelişmesinde çok büyük önemi olan ve ruhun lafza; kastin kullanılmıș kelimelere üstün tutulmasını emreden ku büyük prensip büyük ihtilaflar içinde doğdu: «Causa Curiana» diye meșhur olan davaki bir Poma vatandaşının buraktığı vasiyetnamenin bir hükmünü tef sirden doğmustu - bu ihtilafların güzel misallerinden birini teșkil eder. Cumhuriyet devrinin sonlarına kadar ilim ve kararlar lâfza bağı tefsi rin ve șerh usulunün üstüne çkamad. Cuq derki (cilt II sah. 43) klâsik devir hukukcular «selefleri gibi yani kendilerinden evvel gelmisler gibi lafzî tefsiri ihmal etmediler: Ilk ödevleri metnin șerhi olduğunu unutmaủlar: Bütün ihtimamlarım kanunlarda ve hukukî muamelelerde kullanılmıș ve manaları açık o!mayan sözlerin manalarını tesbit etmeğe hasreylediler. Açık ve dosdoğru bir dilin; ihtilafları önlemekte ve mzıkçılığ bertaraf etmekteki kıymetini biliyorlardı; hukukçular ve dil bi!ginleri kelimelerin manalarina dair eserler yazıyorlardı.

Klasik hukukçular laf́á bağlı, tefsire bağli kalmakla beraber tefsir sahasını genișlettiler; kanun koyucusunun fikri; doğru olmayarak ifade edilmiş olâuğu takdirde onun hakiki fikrini bulmak ve kanunun ruhunu lafzına üstün kılmak lâziımgeldiği esasını koydular. Bunun için de Ciceron ve Cumhuriyet devri sonu belagatçları tarafından öğretilmiş iki usulï kullandılar. Bu usullerden birinicisi Gramere göre tefsirdir ki kelimenin iștikakından; güçlüğe sebep olan kelimenin ilk ve esas veya kullanmakta olan manâsinłan ve gramer kaidelerinủen istifade etmekten ibarettir. Ikincisi mantıka göre tefsirdirki manası araktırılan müphem ev iki manaya gelen metni aynı kanunun diğer kısımlarındaki metin. lerle yahut ayni maddeye benzer maddelere dair çıartılmış olan diğer kanunların metinlerile kașlaștırmak; kanunun gayesini (rotie legis); yahut gerekçesin! (ocrasio legis) araştırmak ve nihayet teklif edilen tefsirin faideliye; namusluya ve nasafete uvgun olduğunu ve kanunun lafzi ile tatbik edilmesinin mantıksızlığa sevkedeceğini ispat etmekten ibarettir. Mantıkî tefsir kanunun görünen sumuiünü genișletmeği veya daraltmağl istihtaf eder: Kanun bazen; sarahaten içine girmeyen ve fakat $\mathrm{ru}^{-}$ 
huna uygun olan hadiselere teșmil edilir; bazen de kaanunun metnine girer vibi gözüken ve fakat ruhuna uygun düşmeyen hadiseler kanunun tatbikinin dișinda kalır.

Gramere göre tefsir hakkında burada fazla bir șey zikretmeğe lïzum yoktur̂. Ikinci tarz tefsir hakkunda Digestada meveut $(1,3,17)$ şu cümleyi zikretmek kâfidir. «Kanunları bilmek !afizlerini bilmek demek değildir; belki kuvvet; gaye ve ruhunu bilmektir. Ciceron «Hereniusa belagat» adl eserinde (Ikinci kitap No. XI) șöyle der: «Metnin çeşitli iki veya daha çok mana çıkartılabilmesinden dolayı müphem olduğu. kanaatına varı!ırsa șu suretle hareket edilmelidir: Evvelâ hakikaten iki veya daha çok manaya gelip gelmediği araştırılmalıd̆r. Ondan nuarızlarımızın metne vermek istedikleri manayı metin sahibi kastetmis ols i idi nasıl bir ifade tarzı kullanmıș olaçăını gösternek lâzımdır; daha sonra bizim verdiğimiz mananin mümkün ve muhtemel olduğunu vé namusa; doğruluğa, kanuna, adète tabiata, iyiliğe ve nesafete (bono et aequo) uygun olduğunu göstermek lâzımdir. Hasimalrımız için iş bunun tamamile aksidir. Zaten müphemlik de yoktur çünkủ gerçek mana görülmektedir.»

Yine Ciceron ayn eserinde (Ciceronis ad Herennium L. II; X) kast hakkında șöyle demektedir: «Eğer kast ve ruhu müdafaa ediyorsak evvelâ metni kaleme almış olanın vạcia tarz̆n methedeceğiz. Metinide ancak lâzım olanı yazmış ve metne hacet olmaksızın anlaşılan şeyleri metinde aymca bildirmeğe lüzum görmemiş olmasını metheteceğiz; bundan sonra mana ve ruhu bıraip kelimelere ve lafizlara bağlanmakliğin kötü niyete mahsus bir hal o!duğunu söyleyeceğiz. Daha sonra metinde mevcut olanın yürütülemiyeceğini veya kanuna, 'adete, tabiata, nasafete muhalefet etmeden; metnin muharririnin tamamile riayet eylemek istemiş olduğunu șüphesiz olan bütün bu șeylere muhalefei etmelon yürütülemiyeceğini söyleyeceğiz. Bizim hareketimizin de adalete uygun olduğunu bildireceğiz. Zaten hasım!arımızın fikirleri kabili müdafaa değildir; çünkü ya akla, hakka aykırı, tatbiki gayri mümkün, evvelinde veya ardında gelen manaya muhalif, müşterek kanun ile ve diğer genel kanunlarla veya mahkeme kararlarile tezad halindedir. Buntan sonra kasta ve ruha uygun; lafza muhalif kararlar zikretmeli; ondan sonra içinde; yazmış olanların kastları tefsirir edilebilmek kastile toplanmıș kısa kanun veya mukavele metinleri okùmalıdır. Yazanın düşünce ve kastını aramaksızin bir metin okuyan kimse aleyhinde; ilham kaynağı budurs.

Tefsir hakkında Ulpianus'un Digesta'da yazılı $1,3,30$ ) su söziinü 
de arzeylemek lâzımdur. «Kanunun istememiş olduğu bir șeyij; o \$̧eyi - kanun açkca yasak etmemis olsa dahi yapmak kanuna kar hiledir. (Fraus) Kanuna karşı hileyi kanuna muhalif hareketten ayuran şey lafzi mana ve ruhtan ayıran șeyin aynıdır.x

1 -. XII laha kanununun çok dar tefsirine karş uyanan itirazların (Summun jus; summa injuria) sözünde hülâsa edildiğini söylemiștim. Bu sözün kelime bekełime tercụmesi en büyük hak en büyük haksız'ıktır. Bu sözün tefsire ait olduğunu iddia eden (Munich Universitesi eski diller profesörü Stroux (Ein Kàpitel aus der Geschichete der Interpretatio juris; Berlin 1926) söyle tercüme edilmesini teklif ediyor.

«En strict (sert) hukuk en büyük haksızhı̆g çevrilir.»Bu tercüme tarzi islam hukukunun kanun hükümlerinde arađiği hassayi izâh ederi. «nâsa erfak olmak» yani hükümler ha!ka yumuşak ve tatlı olacaktır. Nasa efrak olmayan hüküm!er zalim hükümlerdir. Bir kaç kerre arzeylediğim gibi en sert hükümlerin en büyük haksszlığa çlvrileceği kaiclesi ilhammı Aristotalisten alır. Çünkü Aristonù nasafetinin mahiyeti kanunun bir düzeltilmesi olmasıdır; kanunun bozukluk gösterdiği hallerde düze!tilmesi clmasidır. Demek ki Aristotalise göre nasafet; hukukun neticelerin - de kendi kendisine aykırı düştügü ve dar tefsirinin haksızlığga varacoğg yerlerde ve hallerde bahismevzuu olabilir.

Burada uzun uzadya dahseylediğimiz adalet veya dilimizdeki - diğer șklile hakkaniyet; namuslu olmak, iyilik ve nasafet kavramlarını șimdi Ciceronun agzından dinleyelim.

«Ahlakın diğer șekillerinden sahasi en geni olan içtimaî bağları ve insaniar arasindaki müsterek hayatı tutmağa matuf olanıdır. İki kısmı ihtiva eder: Hakkaniyet veya adalet (justitia) ki her faziletten en parlak bir fazilettir. Fazilete sapmiș olanlara namuslu adam cenir ve iyilik etmek bu faziletten ayrı!amaz. Buna iyilik (șefkatli bir iyilik) veya bağıslama (bağıslama iyilik) adını vermek caizdir. Hakkaniyetin birinei vezifesi kimseye zarar vermemektir. Meğer ki yapılan haksılık zanar vermeğe mecbur biraksın; bundan sonra hakkaniyet insan, müșterek menfaatlardan, onların müsterek menfaat olmak karakter!erini : muhafaza ejerek faydalanmasıdır; kendi malıncan da kendisi için kullanzcağ bir şey gibi tasarruf eylemesidir Zaten tabiatın bir kișiye özel kıldığı bir mal yoktur. Insanin eski bir isgal ile; harbin bize sahip kılması takdirinde zaferle, veya bir kanun ile (sahipșiz bir ma! iktisaba müsaade eden 'kanun ile); bir sözleșme ile; bir stipulatio ile; ad çekimi (kur'a) ile malik olunan mal vardır. Arpinum arazisi (Ciçeronun doğduğu yer) kendi 
halkınındır. Tusculum arazisi kendi halkınındır ve böylece fert!er de kendilerine ait olana kendi adlarını vermektedirler. Bundan çıkan netice tabiatile insanlara müşterek olan servetlerden baaısı mullk edinilince onun, malikine ait o!makta devam eylemesi lâzımđ̊r. Dlğger blrisi cikı̀ ta almak ister ise içtimaî hukuka aykur hareket etmiş olu:. Takist Eflatun'un pek jyi bir tarzda söylemiş olduğu gibi biz yalnız kenủiniz iẹin değiliz. Vatan varliğımızdan hissesini istiyor: dostlammızın da bizde hakları vardır.

Ístoysyenlerin pek iyi anlamıs oldukları gibi yerin bütün yemiş!eri ve mahsulleri insan için var oluyorsa insan da insanlar için doğmaktadir. Tabiata uyarak müșterek menfaata hizmet etmeliyiz; birbirimize kars; lık! hizmetlerde bulunmalıyı. Vermeli ve almalıyı; istidatlarimızi kabiliyetlerimizi; bütün vasıtalanmızı içtimai bağiarı sıkmağg kullanmalıyız. Hakkaniyetin esaslı prensibi; ana prensibi doğruluktur; yani sözlerde samimiyettir; alınmıș taahhütleri tutmaktı:. Bu bizi; kelimeñin menşeine çkan istoysiyenleri taklide sürüklüyor ve uğrayacağımız tenkitlere rağmen fides'in (doğruluk; vefa) fiat'tan geldiğine inanmağa cesaret veriyor.,, Fiat" söylenmiș olan șey «olsun» demektir. (Cicero tarafından yapılmis cüretli bir iștikak).

Iki türlï haksızlık (eski hukukumuzdaki tabirle zulum) vardır: Bizzat iş!enen zulüm ve başkaları tarafından ișlenen zulme karşı koymamak; yani mümkün olan ile mükavemet etmemek. Hiddet ile veya herhangi bir ihtiras ile hareket eden kimsenin baskasına saldırması o adamin bütin insan cemiyetine el kaldırması olur. Bir haksızlık karsısında hareketsiz duran ve haksızlığın işlenmesine engel olmıyan kimse ise ana babasını; dostlarını, vatanını terketmek suçunun aynıni iģlemiş olur (1).

Başkasına zarar vermek kasdile yapılan haksızlıklarin kaynağı ekseriya zarara uğramak korkusudur. Uğratılacağından korkulan zararı önlemek için yapılan zarardır. Faǩat çok kerre haksızlık üzerine göz atılmış bir şeyi elde etmek için içlenir. Bu suçun işlenmesinin a!ggan sebebi kazanç hırsıdır. (Ödevler 1;7).

«Bununla beraber bazı haller vardirki adil bir adamin yani namuslu olduğunu söylediğimiz bir adamın hareket tarzının mahiyetini değiştirir, una ters bir mahiyet aldırır; meselâ bir vedianın (emanet olarak b1rakılmış șeyin) iadesi veya bir vaidin (verilmiș sözün) tutulması vakıa-

(1) Islam hukukunda fert islenmekte oldugunu oördügü zulme filen karsı kovmaklo müküelleftir. Filien mukavemete gücú vetmivorsa dil ile karșı kovacaktır; buna da oücê vetmiyorsa kalben nefret (bugz $=$ sevmeme) besliyecektir.

Hukuk Fakültesi Mremana : 19 
larında adaletin sözünü tutmamak ve kendini yüklenmiş olarak kabul etmemek olacağı vaziyetler ve haller bulunabilir. Bunu anlanak için koyduğumuz esaslı prensipe müracaat edelim: Adalet kimseye zarar vermemekten ve müșterek menfaata hizmet etmekten ibarettir; vaziyet!er değișince hareket tarzı da ahlaka sadık kalmak için değișmeğe mecbur kalir ve aynı kalamaz. Yerine getirilmesi vadedene de kenðisine karș vadolunun kimseye de zarar verecek taahhütler vardır. Meselâ trajedide «N - unus» 〈Theseus» a yapılmış vaidi tutmamis olsaydı «Theseus. oğlu «Hippolyto» yu kaybetmiș olmazdı (1). Theseus yapabileceği üç istekten; bir kızgınlık eseri olarak yaptığı üçüncüsünün tesirile oğlu «Hippolyto» öldü. Isteği yerine getirilince büyük bir mateme düstü. Binaenaleyh verilen sözün tutulması; söz kendisine veriimiș kimseye zarar verebilecek : ise o söz tutulmamalıdır (2): Yine insan sözünü tutmakla, yapacağ hizmetin kıymetini kat kat aşan bir zarara uğrayacak ise az hizmet ve iyiliği; çok zarara üstün tutmamak; azı çoğa tercih etmemek ahlaksızllk olur: Mesela bir davacinin avukatı olmayi kabul ettikten sonra davaya tutuşacağın zamanda oğlun ă̆ır surette hastalanırsa* yapacağını söylediğini yapmamakta ahlaksılık ve haksızlık yoktur. Eğer müvekkilin kendisini terketmiș olmaḳlığından șikâyet eyler ise o haksızlık etmiş olur. Ikrah jle hile ile alınmış vaitlere vefa gösterilmemesi lüzumunu kim görmüyor? Kim anlamiyor? Pretörün edicturr'u daima ve kanun bazan seni bu bağdan kurtarıyor.

Hakkı suiistimal etmekte ve hakkı kurnazca yormakta (tefsir etmekte) haksızlik vardır; darbimesel haline gelen «Summun jus summa injuria» düstürü bunu ifade eyler: Bu enviden bir çok ahlaksız hareketler her gün genel menfaat namina irtikap olunmaktadir. Düșmanile 30 günlük bir mütareke yapmasına rağmen onun arazisini gece!eri tahrip etmekte devam eden bir komutandan bahsederler. Komutan yaptığı mütarekenin gündüzlere ajt olduğunu ve gecelere tatbik edilemiyeceğini söy lemiș. Ișitmiç olduğum bir hikâyeye göne; eğer o hikaye doğru ise bizim Quintus Fabius Labeo'nun da hareketi tasvip edilemez: Senato tarafından bir arazi hakkında Nolanis ve Neapolitanis halkları arasında ha: kem olarak tayin edildi; mezkur yer halklarını evvela teker teker yanlarına çă̆ırdı ve onlara haris olmamalarını ve iddialarını biraz azaltma-

(I) Thèseus evvela cehennemden çıkmağı, sonra labirentten çıkmağı, üçüncüsü oglu Hippoiytonun ölümürü istemisțir.

(2) Ahlak ve adalet zarar vermemekten ibaret olduŏuna göre sadinin ezarar veren doöru, ivilik yapan yalandan kötüdür sözü ayni hakikati ifade etmis oluvor. kTabibin kizbi de olsa marizin sihhatin söylüyors (Ziya Pașa). 
ları lâzım olduğunu bildirdi. Her taraf bu nasihata uydu ve böylece ortaya hiç bir taraftan edilmeyen bir arazi parçası çıłıtı: Labeo her iki tarafa iddia eyledikleri sınırları verdi ve ortaya çımıs $\cdots$ olan araziyi de Roma halkına verdi. Bu bir hüküm değildir; bir aldatmadır. Her seyde böyle kurnazlık ar (maharetler) göstermekten kaçını malıdir. (Ciceron; ödevler $1 ; \mathrm{X}$ ).

12 - Aristotalisin nasafet telakkisi istoysiyenlerin telakkilerinden daha konkret olması olaylara daha yakin bulunması, hem yargıclar hem de davacilar tarafindan daha kolay anlaşılması itibariyle orta çağda galebe çaldı. Bu galebenin delilini Bracton'un XIII üncü asırda yazdığı eserinde buluruz. Roma ve Klisa hukukları bilgini olan Ingiliz Bracton «De Legibus» adlı eserinde nasafeti şöyle tarif eder: «Nasafet eşyalarin o münasebetidir $\mathrm{ki}$ (est rerum convenientia) eșit ve birbirine benzer sebeplerde eşit haklar icabettirir ve her şeyi eşit kılar».

Nasafet bir nevi eșitliktir Bracton nasafet hakkındaki doktrinini, şu sözlerle bitirir: «Adalet adillerin fikirlerindedir.» Adaletin bulunduğu, yer yerleștiği yer adillerin kafalarıdır.»(1)

Yine XVI inci asrın başlarında nasafet fikri daralyyor. 1520 tarihlerinde «Doktor ve talebe» adı altında herkesin anlayacağı șekle: kolay anlașilır şekle konmuș olan bir konuşmada Ingiliz nasafetinin bir tarifine rastlanır; ki Aristotalis'in dar tarifinin: «azamî adalet azamî adaletizliktir». (Summun jus summa injuria) sözünün tekrarındən ba ka bir șey değildir.

Ingilizlerin nasafeti anlayıșı ve Ingiiliz nasafet hukuk, Ingilizlerin nasafeti anlayıșları İstoyisiyenlerin nasafeti insanın insan ile olan ortansi şeklinde vaki anlayıșlarından bambaşkadır. Hattâ Ingiliz nasafet anlayıșı orta çağın nasafet anlayıșından başkadır. Nasafetin Ingilteredeli anlamı sırf teknik bir anlamdir; Positif hukukun (mevzuu hukukun) metinlerinin veya adetin sert tatbikinden doğabilecek hataları, ahlakı ve vicdanı incintecek hataları düzeltmek gaye ve çaresidir; düzeltme aletidir.

Pretörün bir nasafet hakimi olduğunu söylemiştim. Ingiltere-

i1) Ädil kim dir? Bu suale fikıh iyitiŏi kötülüŏünden fazia ve üstün olan, iyilioi daha agır basan kimsedir diye cevap verir. Ádil olan kimse her kese karsı eadalet ve müsavat ile hareket eder. Hasimlere adalet ile memur olan yargicın hareket tarzını mecelle sövie anlatır: Taraflardan biri her ne kadar eșaftan ve dižeri ahadi nastan olsa bile varoılanma esnasında tarafları oturtmak ve kendilerine göz cevirmek ve söz söylemek aibi yaroılama ile ilgili muamelelerde tamamile sadalet ve müsavata riayet etmesi $\|$ a. zimdir.s (mecelle mad. 1799) 
de pretörün yerini Şansöyle (Lord High Chancellor) aldı. «Common Law» a göre verilen kararìarın adaleti incittiği takdirde bu kanunî hükümlerin düzeltilmesi için, adaletin en büyük kaynağı sayılan kra!a istida verilirdi. Kral kendisine verilen istidaların tetkikini șansölyesine vé maiyetine bıraktı. XIV. üncù asırda Eşikye de (Exchequer) de (1) olagan yargı yetkisinin yanı bașında nasafete dayanan bir yargı yetkisi daha aldı.

Romada olagan yargıç olan pretör tercihine göre kanuna veya nasafete göre yargıladığı ha!de Ingilterede nasafetle yargılama yetkisi özel kurullara verildi. Bu özel kurullar; olagan kanun ile yargllayacak kurullara simetrik (mütenazir) idi.

Olagan hukuk (Common Law) kurulları: Eşikiye; kralın Bank'i ve Plaids Commons idi. Nasafet divanları ise şansölye ve nasafet ișinde Essikye ve saire idi.

Common Law (hukuku adiye) mahkemeleri ile nasafet mahkemeleri arasında uzun zaman zitlık oldu. Common Law (adi hukuk) mahkemeleri emsallere, eski adetlerin lafızlarına sıkı ve sert bir tarzda bağlı idi. Na-

(1) « Satraç gibi garip bir manası olan bu adın, salianatın malivecilerinin, üzerindeki örtũsú sivah ve beyaz hanelere ayrılmıs bir masanın etrafında toplanmak adetlerin. den cıkmıs ve alınmas olduð̆u söyllenir. İsim masadan ve örtüden masanın etrafinda toplanan adamiara gecti. Masanın etrafında, bir uclu diğer uça oturanlar arasında vapılan iptidaî muhasebe usullerinin icabettirdiği bazı jeton alıp vemeleri de satranc oyununu hatırlatırimiş. Bugün ingilterede merkezdeki malive idaresine verilen addir; rarihine Fransız krallarının savıștaylarından daha mütevazi bir hal ile başlanmıștır. Gö. revi itibarile üye olanlara Kralın yargı. kurullarından vaki toplantı için tavin edeceăi kimselerden mürekkep olan malî kurui eski kral sarayı olan Westminister’in büyük. Esikye salonunda veva mümessilinin baskanlığında toplanırdı. Yargı görevine mensup olan üyeler mahkemeierde «usticiariis unvanını, Westminsier,in satraçlı masası etrafında da Esikiye baronları unvanırı tașirlardı.

Bizim tarihimizde divan! humayun (Padişahın divani, meclisi) adı ile anılan meclis, firansada heveti umumiyesile Devlet Surasi Ingiiterede ayni manada olmak üzere *Curia Regiss adlarile anilırdı.

Eski sakon Kratlarının divanları frenk krallarının divanları gibi iki kısma ayrılmıştı. Bir! idarî ve siyasî işlerle mesgul olurdu ve bu kısım Fransada büyük Danıștay adını tasırdı; diğeri yargı işlerivle meşul olurdu ve bu kısım da Fransada «cura regis» adını tasırdı; cura regis fransada adalet divanı olan \&parlement» adını aldı. Ingilterede ise aparlement» adı siyasî meçise verildi. Isler cogaldı Fransada «parlement» Ingilterede curia regis bu islerdi görmege vetişemez oldular. Ingilterede curia rogisin zararına ola. rak üc adalet divanı kuruldu.

Esikve saltanatın gelirlerine ait davaları görürdü. Eşkive mahkemesi Ingilterenin üc büyük divanında biri idi. 2 - Ikincisi ferdiler arasındaki davalara bakan \&Common Ple. ass yani «hukuku adiye mahkemeleridir. Please kelimesinin Fransızcası «Plaids» dir ki vargı meclisi manasına gelir. Eski tabirimizle «meclis - j ser,> demektir. Bu eski kelime 
safet mahkemeleri de çok eskimiş adetlerin azamî sertliklerini düzeltmeğe memur idi. Dizbagı nişanınin mucidi olan üçüncü Edouard devrinin (1327 - 1377) nasafet yargıçlan nasafetlerinin prensibini Roma ve Kilise hukukçularından almışlardı. Bu zamanlara ait olmak üzere denebilir ki Common Law Ingiliz hukukunun lâfzıdır; nasafet ise onun ruhudur. Nasafet mahkemelerinde de diğer mahkemelerde olduğu gibi bir gelenek, yavaş yavaş vücude geldi ve yerleşti. Binaenaleyh nasafet mahkemelerinde de «adamların kalblerinde yazılmış olan nazarî ve mücerret adaletin kaideleri» yerine eski nasafet yargıçarının kararlarile yarattıkları emsal zikredilmeğe başlad. Lord Nottingham 1676 senesinde demiştir ki: «nasafet yargıçına rehberlik eden vicdan. kelimeyi adi (olagan) manasile kullanarak diyorum ki her kesin malik bulunduğu tabii vicdan değildir. Yargıcın hukukî ve siyasî vicdanıdır».

Common Law kadar sert, bir positif nasafet hukuku vücude geldi. Blackstone demiştir ki : «Nasafet her münferit halin muhad olduğu ahval ve şeraite bağlıdır. Nasafet hakkında sabit kaideler koymak nasafetin cevherini feda etmeğe ve nasafeti positif hukuk haline sokmağa sürük-

avukatların müdafasına itlak olunan plaidover tabirinde yasar. 3 - (Kralın sediri) (üzerinde oturulansedir sıra, koltuk, kerevit, bank ve sire) manasına gelen (King's Bench) úçuncü divanı teskil edivor ve cinavet davalarile amme kudretine karșı işlenmis cümümleri, hülasa saltanałı ilgilendiren isleri görüyordu. Kralın sahsına bağlı olan bu divan Kralın bulunduğu yer veya şehirde toplandığından sabit bir vere malik değildi. Bu diva na kkoltuk mahkemesis adı büyük fermen zamanından itibaren verilmistir; cūnkū hukuku adive iși kendinden alınmıs ve kralın oturduğu sıra, yer bırakılmıștır. Krala mahsus olan verin muhafaza edilmis olması. kralın adalet islerine ve idaresine sahsen katılabıleceğine işaret idi. Fakat Kraliar bu haklarını kullanmaktan vazgeçdiler ve haklarını kullanmamakla gavip evlediler. Buna rağmen mahkeme ismini, gördüğü işlerin saltanałı illgilendirmesinden, muhafaza evlemekte devam etti. Eşkivenin mahkemesi XIII üncü asırda vetkisini, diğer mahkemelerin zararına olarak arttırmaga uğrasstı ve Kralların bu hare kete karsıı bir kaç emirname çıkartmalarına sebebivet verdi. Esikve yargıslarının meslekî açaözlülükleri gidecegimiz genisleme hırsłarı, Kralların her tarafa düzen ve görevlerde ihtisas yaratmak gavelerine aykırı düşüyordu XIV üncü asırda malî görevleri inhitada doğru giden Eșikye'nin yargı hırsı etrafı kaplayordu. Kral yargı erkini curia regis'den iştikak evlemis adalet divanlarina vermekle beraber en büyük nasafet vargıci almak görevini muhafaza edivordu. Af veva imtiyaz ve lufuf halleri, istiraki olmaksızın müzakere edilemivecek ve bir kararc bağlanamayacak hallerdendi; bu sebebden bu gibi haller sansölye tarafindan Krala arzolunurdu. Fakat yavas yavas sansöyle bu hálleri Krala arzetmekten vazgeçti, ve kendi görmege başladi. Bu adeta saltanatın vargı erkinin ikinci defa olarak teftis edilmesi olmuştur. Sansölyenin nasafet yargısı bu halden sıkmiş ve gelissmisstir، Esikve de aynı derecede nasafetle vargılanmak yetkisini aldı. Bu da XIV üncū asırda Eskiveligin dördüncü taksimini vucuda getirdi. «The court of Exchequerin Equity) (Esikvenin nasafetle vargıloyan divanı). Eșikvenin nasafatle yargı yetkiși 1841 de iloa êdilmiștir. IGlạsş̧n, 
lér. Nasafetsiz kanun (hukuk) ne kadar sert olursa olsun, kanunsuz nasafete çok fazla tercih olunur. Çünkü kanunsuz nasafet her vargııç ka" nun koyucu kulacak ve sonsuz bir kargaşalık vücude getirecektir. O zaman mahkemelerimizde bir hareket tarzı hakkında insanların ceșitli olan kabiliyet ve fikirleri kadar cok çeșitli kaideler görülecelstir». Nasafetin Blackstone'un yaşadığ XVIII inci asırda mevcut olmayan sabit kaideleri artık bugün iyiden iyiye yer!eșmiş ve ruh denilen nasafet Common Law gibi lafiz haline gelmiștir. Lord Eldon'un șansölyeliğinden itibaren nasafet mahkemeleri de Common Law mahkemeleri gibi münhasiran emsallere ve statuts'lere göre karar vermeltedir. Ingiliz nasafeti mahkeme kararları içinde donmuș bir hale gelmiştir ve positif hukuku düzeltmek hukukun bir şekli olmuştur. Nasafiet mahkemeleri önüne; Common Law'in derpiş etmemiş yani görmemiş ve nazara almamıs oldu. ğu ihtilaflar arzedilmektedir. Common Law'ın nazara almıș olçuğu ilıtilaflardan hangisinin nasafete ve hangisinin Common Lav'a göre görülüp çözülmesi lâzımgeleceği de bir çok yetki ihtilâflarma yol açmıştır.

Bu ihtilaflar 1873 tarihli «Judicature Act» çok azaltmıştır. Bugün Common Law ve equity bu «act» in 26 inci kısmında yazıll hüixümlere göre düzenlenmiştir.

Fikirler ve kelimeler de canlı mahluklar gibi hayat için savaß̧ılar ve. intikamlarını alırlar. Nasafete ikinci mevki bir yer verilmesi mese!eyi halletmiş olmadı: Gerçi Nasafet, gittikçe manası daraltılarak, sistematik bir hale sokularak Ingiliz Genel Hukuk sisteminin ikinci bir teknik kolu haline sokuldu. Gerçi 1873 den beri nasafet, kiminin örí hukukit, kiminin hukuku adiye diye tercüme ettiği Common Law ile birlikte mahkeme kararlarile gelișmiș ve yazılı olmayan Ingiliz hukukunun ikinci dilı, ikinci kısmı haline gelmiştir. Fakat nasafetin, ahlaktan böylece uzaklaşarak positif hukuk çehresini almış bulunması onun hayatı için sava, masını ve savaşmakta kalmasını önleyememiştir: Kuvvet - fikirler olduğu gibi kuvvet - kelimeler de vardır. Nasafet kuvvet halinde bir kelimedir: Bu kuvvetin bizzat Ingiliz hukukçularmın düsünce ve mesai'eri izerinde müessir olmakta ve eski Roma ve kilise hukukçularinın nasafetle vermiş oldukları manayi kısmen diriltmekte bulunduğunu Levy - Ụ!lmann söyliuyor: Levy - Ullmann bu iddiasinı nasafet kaide ve mücsseselerinden çıartılmıș su iki prensibe istinat ettiriyor:

1 inci prensip. - Müsavat nasafettir: «aquititas est aequtas». Inği lizler «nasafet, zevkini ve saadetini müsavatta bulur» diyor!ar:

2 inci prensip. - Nasafet haktan ziyade tazifeye bağlıcin manasına olmak üzere: «nasafet şahsin üzerinde işler» (Equity acto in personam). 
Nasafet vicdanları yargılar ve ihtilaflarını çizer. Bịr insan verecekli ise ödemek vazifesidir. Eğer hukuk iģe karıșiyor ise alacaklıya hakkını aldırmak için müdahale etmiyor verecekliye vazifesini gộrdürmek için müdahale eyliyor.

Islam peygamberinin ölümünden evvel vazifesini yerine getirmek endişesile «kimden aldım ise iște kesem; kime vurdu isem iște arkam» demesi nasafetin ameli ve amelî olduğu kadar ulvî bir ifade ve tatbikidir

Yine Levy - Ullmann diyorki : Nasafetten çkan prensipleri Amerikan hukukçuları Ingiliz hukukçularından daha iyi sézmişlerdir. Amerikan nasafet görüşü belki yarınki hususi hukukun, yarınki amme hukukunun ve devletler arası hukukun cevherini teşkil edecektir. Amerikan görüşüne göre insan ve milletlere ahlak namina düşen payı ölçmek ve tayin etmek için; eski Roma ve Yunanın mirasçları olan büyük filosoflar tarafından tasavvur edilen ve istenilen nisbetli (orantalı) müsavatı insanların ve milletlerin aralarında kurmak için hukukun yüksek bir kavram olan nasafet kavramı adına oynamağı istihtaf eylediği amaç ihtilaflara hukuk yargıçı olarak müdahale etmeyip ahlâk yargıçı olarak müđahale etmektir.

Medenî kanunumuzun «herkes haklarını kullanmakta ve borçlarını yerine getirmekte hüsnüniyet yani nasafet kaidelerine riayetle mükelleftir» diyen 3 üncü maddesi acaba Türk yargıçlarını Amerikan büyük hukukçularının dileği üzere hukuk hakimliğinden çıkartıp ahlâk hakimi yapmamış mıdır?

13 - Hüsnüniyet ve nạsafet ayni seyler midir?

Efsaneye göre tanrıca «Ficies» veri!miş sözleri, yapilmış taahiütleri himaye altına alırmış. Fides'in aracası «vefa» dır: Dinî hukuk yani '«fas» sözünde durmayan adamı lanetli sayar ve öldürürdü.

Soniralari «Fides» laikleștirildi, yani dinî bir kavram olmaktan çıkıp felsefi bir kavram olçu. Bu değismede stoa mektebinin büyük tesiri görüldü: Fides'in ahlakî telakkisini Cicero bize «ödevler» adlı eserinde anlatmıştır: «Söylenmiş ve kararlaștırılmıฐ̆ sözlerde doğruluk ve sebat. Verilmis sözlerde ye yapilmış taahhütlerde samimiyet ve onlara sadakat yani vefa (Fides) adaletin temelidir.» (Ciceron'un ödevlerdeki bu yazısını yukarıda nasafeti anlatırken naklettim, I,7): Vefays da Asım Efendi kamus tercümesinde «aht ve peymanı nakz eylemeyip (bozmayip) muhafaza eylemektir; ahte gadretmemektir» diye tarif eyliyor, Peyman aht ile aynı manadadır. Șöz ve karar dẹmektir: 
Fides laikleșüpte hukuka girdiği zaman «bona fides» adını aldı. El kah, adının eski şeklini muhafaza ederek «vefa» demekte devan etti:

Medenî kanunumuz «bona fides» tabirini «hüsnü vefa» sözü ile ifade etmedi; «hüsnüniyet» dedi İslam peygumberinin taşıdığı «emin» sıfatında «Fides» hissedilir: Sözlerindeki daimi doğruluğun ve sözlerinde durmasinin ifadesi olan «emin» lik güveni anlatir. Asin efendi «emanet» kelimesini bazllarının adalet ve bazılarının akil ve tefsir ettiklerini söyler. Hüsnüniyet iş niünasebetlerinde namusluluktur: Namus'u adam nasafetli, insaflı adamdır: Romada objektif hüsnüniyet davalarin dar hukuk ve huüsnüniyet (veya nasafet) davası olmak üzere ikiye ayrı!masına sebep oldu: Dar hukuka bağlı davalarda bir kanun metni dermeyan ediliidi: Nasafatın dermeyan edildiği davalarda yargıç; pretörün vermiş olduğu talimatın (formülün) lafzile bağlanmazdı; halbuki dar hukuk davalarinda yargıç hükmünü verirken, kendišine bu yetkiyi veren pretö:ün vermiş olduğu talimatın lafzile sıkı bir surette bağlı kalırds.

Davalarda yapilan bu ayırmanin tarih ve ehemmiyeti Ciceron un ödevlerinde mevcut çok önemli bir kayıddan çıartılabilir. «Büyük kesis olan Quintus Mucius Scaevola en büyük kuvvetin, içine - hüsnüniyet dairesinde sözünün katı'mı ve yazılmıs olduğu davalarda bulun luğunu söylerdi. Scaevola hüsnüniyet tabirinin çok geniş bir kavram olduğunu ona, vasilikte. ortalıkta, vlfalı muamelelerde (1) vekâlette. alım satım-

da; kirada yani bir hayat ortaklığın icabettiren muamelelerde rastlandığını düşünürdü. Scaevola'yả göre yargıcın vazifesi birinin diğeine ne vermesi veya yapması lâzım geleceğini tesbitten ibarettir»: (Ölevlec $3 ; 17$ 70):

Bu metinden çıkan neticeye göre Quintus Mucius Scaevola (Miladdạn evvel 95 de konsul) hüsnüniyetli davalar arasinda bazı mukaveleleri teyid eden davalarla vasilik gibi borç yaratan hukukî vaziyetlerden doğan davalar bulunduğu an!așiliyor.

«Fakat tiyatroyu orada burakalım ve Forum'a geçelim. Pretör duxışmayı açacaktır: Acaba hangi davayı görecektir? Evrak hazinemize ateș vermiş bir kundakçı davasını mı görecektir. Bundan fazla giłli kalması (devlet tarafından duyu!maması) lâzım bir cinayet tasavvur olunabilir mi? (Suçlunun çok kurnaz olmasını icabettiren bir söz). Picerum'lu bir Roma şövalyesi olan, eşraftan bulunan. Q. Socius suçlu olduğunu itiraf eyledi. İște șimdi umumî muhasebe defterlerinde sahtekarlık yapan

(i) (Simdi buntara itimado davanan muampleler deyoruz), 
herif: adı. L. Alenus hazinenin ilk altı memurunun imzalarını taklit eylemiştir. Bundan daha mahirane bir darbe var midur? (1).

Diğei davalara bak! Tolosa (Tulus) altınları işi ki; ah!âk bozukligunun Roma vatandașlarını Jugurthinus'un emrinde Romaya karæ̃1 birer suikastçı yapmış olduğunu gösteriyor. Başka bir ahlâk bozukluğu i̧̧iri hatırla; Tubulusun (412 de pretör idi) bu para yiyen yargıçın ve (kız oğlan kız kalmağa yeminli o!an) Vestales'lerin iffetsizlikleri hakkında (tribun) Peducaeus'un tahkikat talebini hatırla; ve her gün katillere, zehircilere karşı açılmıș davaları; zimmet ve irtikâp suçu için ve yeni bir kanun (Sulla'nin eseri olan Cornelia de fa!sis kanunu) mucibince vasisiyetnamelerde yapılan sahtekârlık suçu için hergün açılan davaları hatırla Şu itham formuilü o sebeptendir: «iddja ediyorum ki hırsızlık senin iștirakinle ve senin tarafından tanzim edilmiș bir płân dairesinde yapılmıştır.» Yani vasinin, vekilin, ortağın, vediayı alanın suiniyetini tesbit eden hükümler ve satıcının yahut alıcının, kiralayanın veya kiracinin sui niyetine karşı verilmiș hükümler ayni sebeptendir; ve nihayet özel bir iște (küçükleri muamelelerinde aldatmayı ceza!andıran). Pletoria kanunu mucibince açlan amme davalarının sebebi budur ve dostumuz Aquilius tarafından konmuș hile davası ki adeta namussuzlukların kirlettikleri bir cemiyeti temizliyecek süpürge darbesiđ̄ir; Aquilius hakikaten hareket edildiği tarzdan başka bir tarzda hareket ediliyormuş gibi gösterilen her halde hile bulunduğu kanaatindedir. Bu kadar fenalıkların tohumlarınin ölmez allahlardan geldiğine inanabilir miyiz? Allah insanlara zeka verdi ise hileyi de beraber verdi. Hile, alçakça zarar vermeğe çalıșan bağıtsız başı boș bir zekâdı̀r. Aynı allahlar aldatmak sanatini; cinayetler işlemek istidadını da verdiler; çünkü bu neviden fena işlere zekasız teșebbüs edilemez ve bu ișler zekâsız işlenemez. Thtiyar süt nine «keșke allah; (Tesalyada bir dağ olan) Pelio'nun ağaçla örtülü yanlarında geminin (argonot'ların üzerinde seferlerini yaptıkları a"go gemisinin) teknesini yapmağa yaramıș çamları hiç devirtmese idi» diyordu. Ben de onun gibi keșke allah insanlara bu korkunç becerik!iliği vermese idi diyeceğim. Bunu pek azı iyi kullaniyor; ve bun!ar da; çok olan ve maharetlerini namussuzca kullanan diğerlerinin ellerinden çekiyorlar. İlâhî bir bağışlama olan akıl ve düsünce insanlara kendi bilgilerj için verilmemisse; aldatmaları için verilmișe benziyor» (allahların mahiyeti 3 ).

Cicer'un naiklettimiz bu metni bize evvelá $A$. - hüsniiniyetli davalàr sayısının Quintus Mucius Ssaevola zamanından Ciceron'un kendi

(1) Bu iki davanın hakikat olmaktan ziyade hayalî olması gerektir. 


\section{zamanına (miladdan evvel 106 - 43) kadar (1) artmamıs olduğunu göster rir.}

\section{B. - Sonra hüsnüniyetli davalarn formülüne «hüsnüniyet mucibin-}

(1) Cesarın öldürülmesinden sonra ikinci üçadamlar idaresi kuruldukta Ciceron, octa. tarafından seriki Antuvan'in kinine terkedildi. Octav'in buna esefle razı olduğu sövlenir. Hürrivet kalkmıs idi; söz sövlenmez. Mademki üç adamlar Hürriveti ve onunla beraber hitabet kürsüsünü yoketmişlerdi, arhk Ciceronun ne kivmeti kalmıs olurdu? kürsüzüs bir hatip, oğultular varatmayan, akısler vermeyen bir sesten, kendi kendine sönmę̆e mahkûm bir sesten başka ne olabilir? Binaenaleyh zaten kendiliăinden susmaða mahkûm bir sesi boğmağa lüzum var mıdır? Antuvan ve Karısı Fluvi, aleyhlerine vazılmıs ve söylenmis en haklı ithamları: «filipikleris söylemis dilin ve yazmıs elin önlerine kesilmiş olarak geldiğini istivorlardı ve bu arzularından bir türlü vaz geçmiyorlardı. Ciceron Latium ovasının bugün Frascali dive anılan eski sehri Tusculum'dan: ölümden sonraki hayat hakkındaki düşencelerini ihtiva eden «Tusculanes» leri yazmıs olduð̆u sehirden kaçmıs ve deniz yolu ile ölümden sonraki hayata kavusacağı yine Latium ovasının bir limanı bulunan Gaete've gelmiști; niveti o civarda bulunan kōskūnde biraz din. lendikten sonra kendisini bekleyen velkenlive bindiği zaman deniz aşırı kaçmakłı. Fakat gemiye gitmek üzere sedvesine bindiăi zaman Celladlar arkasından vetismis oldular. Celladların başında vaktile korkunç ve rüyler ürpertici bir adam öldürme suçu ile itham edilmis ve Ciceron tarafından müdafaa edilerek kurtarılmıs olan Popilius bulunuvordu. Bu adam babasını öldürmüs olmakla itham edilmiști; șimdi de onu mūdafaa etmis ve ağır bir ithamdan kurtarmıs manevi babasını oldürmeğe gelivordu. Ciceron sedyesini vere koydurdu sol elini, daima vaptığı üzerine cenesine götürdü ve katillerine dik dik bak. tı. Dikilmis ve tozlu saçları, sararmıs ve bozulmus çehresi katillerini kısa bir tereddüte uğrattı; arkadaşları Herennius onu boğczlarken onlarda ellerini vüzlerine tutmuşlardı 7(. XII m. e: 43) : Inscanlığın en büyük timsali ve tarafı ile yine insanlığın, Namık Kemalin sinsafsız avcrya hizmetten zevk alan köpeğe» benzettiği en kücük tarafı; bir sahika ve bir uçurum karss karşıya gelmiști. Cellatlardaki bu utanma, her insanı bir Ciceron kılabilecek, yani tabiatin sadece havvan olarak yaratt:ğını küitürūn yarattığ insan haline getirebilecek bir tohumun her insan kalbinde mevcut olduğunu bir kerre daho ispat evliyordu. Fakat hayvanlıktan insanlığa valnız hürriyetle cıkılabilir: hürrivet ve Cunzhurivet insana ve insanlığa itimaddan, güvenme ve inanmadan ibarettir. Ciceron'un kesilmiş kafası ve eli Antuvana, sofrada iken getirildi. Antuvan o kesilmiş kafanın önünde çllgın bir sevinç gösterdi, ve karısı Fulvia bir iğne alarak o susmus dili iğneledi ve ondan sonra bu büyük bas ve bu büyük el Ciceron'un nutuklarının, insan vicdanını ümiłlerle ürperttiren akislerini muhafaza eyleven Forumda eski Acium deniz savasında ganimet olarak alınmıs gemilerin zafer anıtı olarak dikilmis mahmuzlarına bağlandı. Bu belki de kaderin, Antuvan için Actium burnunda doğacak korkunç sonu bildiren bir isareti idi.

Dünya döndü; eski Roma tarihinden ortada valnız bir coğrafya kaldi. Imperatorlarının istipładı altında cökmüs Roma insanlığın kalbinde bugün yalnız Ciceron'un yazı ve sözlerinde vasııyor; o kesilmiș kafa ve susturulmus söz sönmeven şimal vildızi gibi hukukun adımlarını sevketmekte devam edivor. Yunanistanı bütün idbarları üstünde tutmakta ve vaşamakta devam eden Sokrat'ta böyle öldurülmüştü. Papinianus'ta böyle öldūrülmüstü, ve nihavef Imamı Azam da böyle öldürülmüstü. Bugün Abbasi halifelerni. den nam ve nian kalmamıştır; Bağdat esir düşmüștür. Islamiyet ise İmami Azamın dahasinda yasamakta devam ediyor. 
ce» (ex fide bona) kaydı konurdu. Ciceronun bir çok yazılarından vefa ile yaprlmış mukaveleleri teyid eden davalar formülüne «namuslu insanlar arasında nasıl hareket edilmesi lâzım gelirse» (ut inter bonos bene agitur) şartı konurdu. Bu kayıd bize hüsnüniyetin, hüsnüniyetli davalarda aldığı manayı açıllar: Hüsnüniyet, Ciceron'a göre, iş münasebetlerinde; namuslu adamlarin adet!erine uygun bir doğruluk göstermekten ibarettir.

C. - Hüsnüniyetli davalar diğer davalardan fazla bir kuvveti (summam vim), daha büyük bir neticeyi haiz idiler.

Hüsnüniyetli davaların en esaslı neticesi yargıça çok daha geniş bir takdir hakkı vermesidir. Davacı tarafindan ileri sürülen huhukî münasebetin hüsnüniyete göre takdir edilebilmesi hususunda yargıça geniş bir takdir hakkını vermesidir.

Bundan çıkan önemli netice; hüsnüniyeti gözunünde bulundurmağa mecbur olan yargıçın davacının hile ile hareket edip etmemiş bulun]uğ meselesine de vaziyet etmiş olmasıdir.

Ciceron ödevler 3. V . «Insan için en esaslı amaç hususî menfaatini umumî menfaatle eșit kılmaktır: Her șeyi kendisine almak isteyen kimse insan cemiyetini dağıtmak gayesini takip eden kimsedir.

Tabiat, her insana mahza insan olduğu için her hangi bir insana yardım etmeği emrettiğine göre ümumî menfaatın herkesin menfaati olması lazımge!diğini emretmiş bulunuyor».

Ciceron ödevler 3 . VII: «Panetius'ü ahlak ile faide arasında bir ihtilaf olabileceğini, sanıldığ gibi, kabul etmiş olmasından tenzih હylerim. Panetius'a göre ahlâk ile faideli gözüken șey arasinda ihtilaf olabilir. Aynı zamanda ahlakî olmayan hiç bir șey faideli olamaz, ve faideli olmayan da ahlaki değildir. Panetius ahlâk ile faideli birbirin den ayrı iki kavram gibi telakki edenlerin düşünceleri kadar insanlığa zararlı bir şey olamıyacağını iddia eder».

Ciceron ödevler 3. VII. «Faideli gözüken bir şey gözümüze ilişir jlişmez üzerimizde tesir yapar: Fakat bir az dikkatle bakıldığı zaman bu zahirî fäidenin ahlaksızlı! la birleșmiş olduğu görülürse o zaman insan, kendisinde faideli bir şeyden vazgeçmek kanaatını uyandirnayı ahlaksızlığın bulunduğu yerde faide olamıyacağına kanaat uyan'ırmağa çalıșmalıdır. Ahlaksızılık kadar tabiata aykırı bir şey yoktur. Cünkü tabiat istikameti (doğruluğu) ister: insanın tabiatla ve kendi nefsi ile uygunluğunu ister. Diğer taraftan faideli kadar hiç bir șey tabiata uygun değildir. Binaenaleyh faide ile ahlaksızlık aynı konuda birleşemez. Ahlaksız 
insanlarm hataları zahiri bir faideye kaplimalarında, ahlaksiz bir fiilin faideli olabileceğini sanmalarındadır. (Suçıar bu kanaatten doğar).,

Ciceron ödevler 3.X: Dostluk ahlakî hakikatin keşfini güçleştirir. Çünkü insanın dost'arı için elinden geleni doğruluktan ayırmamak şartile yapmak borçtur ve yapmamak insan!ık değildir. Diğer taraftan dosta hizmetetmek için haksızlik yapmalk ta insaf değildir. Bununla beraber bu hususta kısa ve açık bir kaide vardı. Faideii gözüken her şey: şeref, servet, zevk ve eglence ve bunlara benzer şeyler dosluktan yüksek ve kıymetli tutulmaz. Fakat iyi bir adam bir dost için umumî menfaata ay. kırı olan bir şeyi yapmaz; hatta dostunu yargilamağa memur olsa yine de dostu için, doğruluğa ve ettiği yemine aykırı bir harekette bulunamaz. Dostluk için yapabileceği șey dostunun davasının haklı olmasını temeniden ve ona kanunun müsaade eylediği nisbette müdafaa zamanı vermekten ibarettir. Atalarımızın .bize nakleyledikleri yargıçtan talep formülü, riayet edebilecek çok güzel bir formüldür; taraflar yargıçtan bir talepte bulunurken böyle derlerdi: «yemininde hanis olmamak șartile yapabildiğini

yapsin.». Bu gibi formüller bir yargicın bir dosta yapabileceğini istihtaf eyler. Dostlarımızın bizden her istediklerini yapmak lazım ge!se onlarla aramızdaki münasebet bir dostluk münasebeti olmaktan çıkar ve suç ortakları oluruz... Doslukta, ahlaken güzel olan şey ile doslugun zahirî menfaati karşılaștırılacak olursa faidelinin ihmal ve terk edilmesi ve yalnız güzele önem verilmesi lâżmgelir, ve bizden dostluk namına her türłü güzellikten mahrum bir fiil istenirse o zaman ahiaka saygıyı, verilmiș sözleri ve yapılmıș ahtleri dostluğun üzerinde tutmak lâzımgelir.» $\mathrm{Ci}^{-}$ ceron ödevler. 3.XI: «zahirî faideler, en çok devlet ișlerinde fena ișler vaptırdılar.» Ciceron ödevler 3.XII: «Demek ki doğruluğa aykırı bir șeyin asla faideli olamıyacağını bir hakikat olarak alahm. Fena bir hareketin faidesine inanmak bile bir felakettir. Fakat doğruluk ile faidenin birbirlerine aykırı bulunduğu sanıldığı bir çok haller vardır. Bu aykırılığın gerçek olup olmadığını, telifin mümkün bulunup bulunmadığını araștırmak lâzımdır. Așağıda yazılı șu mesele bu nevidendir. Rodosta yeyeceğin tamamile yok olduğu ve hakikî bir kitlık içinde bulunulduğu bir zamanda namuslu bir tacirin İskenderyeden Rodos'a mühim miktarda buğ. day yükü ile gelmiş olduğunu farzedelim. Aynı tacir bir çok tacirin Iskenderiyeden hareket etmiş olduğunu da biliyor. Yolda da buğday yük!ü gemilerin Rodosa doğru gelmekte olduklarını da biliyor. Bu tacir bildiklerini Rodoslulara söylemeli midir; yoksa yükünü daha pahalıya satmak için susmalı mıdır? Tacirin, uslu bir adam, iyi bir adam olduğunu da farzedelim: Eğer bildiğini Rodoslulardan saklamaklığın namussuzluk oldu 
ğuna kanaat ediyorsa onlardan bir şey sak!amayacaktır. Fakat bu tacirin bildiklerini Rodoslulardan saklamaklı̆̆ın hakikaten namussuzluk olup olmadığını soruyor.

Şimdi biz o namuslu tacirin vicdanile yaptığı danışması hakkında nasll düşünmeliviz. $\mathrm{Bu}$ gibi häller karşısında Stoa mektebine mensup filozofların en büyüklerinden olan Babelli Diogen ile içe işleyici (nufuzedici bir zekaya malik bulunan talebesi Antipater ayni tarzda bir düșünmeye varamyorlar.

Antipater her şeyin söylenmis olmasını istiyor, yani alıcının, satıcının bilmekte olduğu her șeyi bilmesi lazımgeleceği fikrinde bulunuyor. Diogen ise yalnız malın kusurlarının, medenî kanunun emrettiği derecede bildirilmesi, geri kalan șeyler hakkında her türlü saniadan (uydurma seyler yapmaktan) kaçınılmasını kâfi buluyor ve madem ki satıcı satiyor, mümkün olduğu kadar iyi satmak istiyecektir diyor ve şöyle muhakeme eyleyor: «malımı (emteamı) getirdim, arz eyleđim, diğerlerinden daha pahaliya satmayorum belki de malın bo!lașacağı zamanda haiz olacağı kıymetten bile daha ucuza satıyorum. Kime zararım dokunuyor?»

Antipater de şöyle muhakeme eyleyor: «Nie diyorsun? sen ki insanlarin iyiliği için çalıșmağa borçlusun, sen ki cemiyete hizmet etmeğe korçiusun, săna ki tabiat menfaatın müşterck meniaata eşit tutmağ emrediyor ve bunun tersine olarakta müșerek menfaati kendi şahsi menfaatın olarak görmeği emrediyor (1) böyle olduğu halde sen onlardan, hayatları için lâzım olan gıdanın gelmekte olduğunu saklıyacaksın ha ?»

Belki Diogen bu düşünüșe șöyle cevap verir: «saklamak başka șeydir susmak başka şeydir; ben sana şimdi tanrıların mahiyetleinin veya en büyük iyiliğin ne olduğunu söylememekle senden bir șey saklamıș olmayorum. Bu gibi bilgiler sana buğdayın fiatı ile așağılık șeyleri bilmekten daha faidelidir. Fakat senin için faideli olabilecek her șeyi söy. lemeğe borçlu değilim-» Antipater ise be!ki: «evet söylemeğe mecbursun» diyecektir «hususile insanlar arasında tabiatın istediği bir cemiyet bağlılığı bulunduğunu hatırlarsan sö̀ylemeğe borçlu olduğunu duyarsın.» Diogen cevap olarak: «evet hatırlyyorum, fakat bahsettiğin cemiyet, bütün hususî mülkiyeti ka!dıracak (ilga edecek) mahiyette midir? Eğer

(1) Stoa mektebi elnsana, cemivete faideli olundan daha faideli ve cemivete za. rarlı olandan daha zararlı bir sey yoktur.s Düsturunu harekei tarzı olarak kabul eder. 
öyle ise artık satıștan bahsetmenin yeri yoktur. $\mathrm{Bu}$ taktirde satmak değil vermek icabediyor.» (1)

Ciceron ödevler: 3 : - XIII «gördüğün gibi, bütün bu tartışmalar esnasında «Bu işi, namussuzluk ta olsa yapacağım çünkü menfaatım vardır» diye bir söz geçniyor. Sadece iş namussuzluk olmaksızın faidelidir denmektedr. Hasım da «yapmamalıdr çünkï namussuzluktur, diye cevap vermeyor. Peki öyle olsun. Şimdi namuslu bir adam evini kendisinin bildi: ği ve fakat başkalarının bilmèdiği kusurlarından dolayı satmak istiyor: ev gaǰrî sıhhidỉr; halbuki sıhhî olarak bilinméktedir, her odasında yılanla" çıkmakta olduğunu bilmeyorlar; çatısı fenadır ve yıkılmağa maruzdur. Bütün bunları sahibinden bașka kimse bilmemektedir. Şimdi soruyorum, satıcı alıcıya bunlardan bahsetmeden satarsa ve düşündüğünden de çok fazlaya satarsa namussuzca ve haksızca hareket etmiş midir? Bu soruya Antipater «muhakkak» diye cevap vermektedir. Antinalıların, ammenin nefret ve kinle karşılanmasına layik bir mürüvvetsizlik (insan sevgisiz. liği) olarak gördükleri bir hal vardır: yolunu kayıpetmiş bir adama yolunu göstermemek. Bu mürüvetsiz hal ile aldanmıș bir alıcının gözü kapalı olarak bir kapana düșmüş olması arasında ne fark vardır? Hatta doğru yolu göstermemekten daha kötüdür, çünkü bir adan kasten hataya sevkediliyor.» - Diogen cevap veriyor: "Seni satın almağa zorlamadilar, hatta seni satın almağa teșvik te etmediler-Satıcı hoșuna gitmeyen bir evden kurtulmak istiyordu; sen de hoșuna giden bir evi satin aldın. Eğer halkın, hatta kaidelerine göre iyi yapılmamıș ve hoș olmayan sayfiyeleri için «iyi yapılmıș ve hoș yazlık ev» diye ilân yapıștırmalari aldatma teşkil etmediği gibi evini, hatta methetmemiș bir adam hakkında evveliyeťle aldatma teșkil etmez. Alıcı takdirini kendiliğinden yapmıș olunca nasıl olurda hileden bahsedilebilir (1) Sattiğı malın beyan ettiği bütün vasıflarından sorumlu olmayan satıcı neden satt.ği mala iza re etmediği bir vasftan sorumiu bulunsun? Bir satıcı için satacağl nalm kusurlarm saymaktan daha manasız ne vardır?

(1) Bu tartısmanın büyük bir önemi varaır; Ciceron da bu tartısmavı anlatırken büyük bir nüfuz nazar gösteriyor. Ciceron bir defa her mücerret ve fikrî düșünüște, düsünenin, karsısındakini hataya sürüklemek gibi bir kasti olmasa dahi, cemivet havatı hakkında beslenilmesi lâzım gelen fikre aykırı bir taraf bulunmakta olduğunu göstermek istiyor. Diogen'in son cevabı cok manalidır: alııının ve satıcının ikisinin de menfaatları. nı aramakta oldukları her ticarî muamele hakkındaki dussüriceler tıcarî muameleyi ademi tasvibe, takbihe ve binaenaleyh hususi mülkiyetin ilgasına doğru vani komünizme doŏru sürükleyebilir.

(2) Diogen'in bu sözleri eski Roma hukuku hijkümlerinin lafiziarına göredir.

(3) «Kimse voŏurdum karadır demez» diven atasözü ile mukayese ediniz. 
Bir münadinin (tellalın) mal sahibinin emrile «satılık gayri sıhhî bir ev» diye bağırtılmasından daha manasız bir şey varmıdır?» Dęmek ki bazı tereddütü mucip hallerde bir taraftan hüsnüniyế diğer taraftan faideli müdafaa olunmakta ve mesnet olarak da menfaatli olan şeyin yalnız şeref ve namusla takip edilebileceği ileri sürülmekle kanılmayıp takip edilmemesile de ahlakî bir zarar husule geleceği ayrıca bildirilmektedir. Faideli bir tarzda hareket etmekle doğru bir tarzda hareket et mek arasında çok kerre, varlığı gözüken aykırıllk iște bundan ibarettir. $\mathrm{Bu}$ çeșitli haller hakkında bir hüküm yürütmek lâzımdır; Bunu söylemekle yalnız meseleyi koymağı kastetmiyoruz, meseleyi çözmeyi de kas. tediyoruz. Bana öyle geliyor ki ne buğday taciri Rodoslulardan ne de evini satmak isteyen kimse alicılarảan bir, amme niç bir şey saklama. malıdır. Bu vaziyetlerde bir șey saklamak sadece bir şey söylemiş olmamak demek değildir; bir șeyi bilmekte faidesi bulunanların o seyi bilmemelerini istemektir; bilmemelerini istemek iradesi, kaynağını bilmemelerindeki menfaattan alır. Bu saklamanın ne neviden bir saklama olduğu görünüyor ve saklayan adamın mahiyetini tayine karine teșkil ediyor. Gerçektir ki saklayan kimse için açlk yürekli, açık sözlü adamdır denemez. Adaleti seven, doğru yürekli, hülasa iyi bir adamdır, iyilik adamıdır da denemez. Bu hareket tarzi: karanlık rehbu, hilekâr, aldatıc1, yalan dolan ișlerinde bilirkiși, dolap kurmada tecrübeli kimselerin hareket tarzlarıdır. Insan lekeleyen bu ad ve sifatların verilmesinl kat. lanmak faideli bir iș sayılır $\mathrm{ml}$ ?,

Ciceron ödevler 3. XIV. - Eğer söylememeği çirkin görmek lâzimgelirse ya aldatmak için söylemeğe ne demeliāir?. Aydın bir romal șövalye olan C. Canius, Sirakus'e gelmiști. Dediği gibi iș için gelmemiști; dinlenmeğe gelmiști. Fakat önüne gelene sıkıcı kimselerin ziyaretlerin den korkmaksızın dostlarile beraber iyi bir zaman geçirebileceği bir sayfiye satin almak istediğini söylerdi. Canius'un bu isteği yayllłr. Mahiyetini anlatmak için Sirakus sarraflarından olduğunu söylemek kâfi ge Ien Pithius adlı birisi Canius'a gelip bir sayfiyesi olduğunu fakat satılık ta olmadığını yalnız emrine tahsis eylediğini söyledi; ayni zamanda da ertesi gün için yemeğe davet eyledi. Canius daveti kabul ettiğinden Pithius sarraflığının, kendisine her sınıf halk üzerinde verdiği tazyił. vasıtalarndan istifade ederek balıççları çağırttı onlara ertesi gün için talimatlarını verdi ve säyfiyesi önünơe gelip balık avlamalarını tenbih etti. Canius, kararlaşturılan saatte yemeğe seldi. Pithius nefis yemekier hazırlatmıştı. Kaıklar davetlilerin gözleri önilude adeta yarışyorlar, her balkcı tuttuğunu getiriyor ve balıklar yığın halinde Pithius'un ayakları al- 
tina düşüyordu. Bunu gören Canius: «Pithius bu ne hal? dedi, bu kadar kayık bu kadar balık» Pitmius cevap verdi: «Bunda șașiracak ne var? Bütün Sirakus'un balıkları buradadır. Burada su tedarik edilir. Balıkclıar evimden vazgeçemezler.» Bunu ișitir işitmez, Canius alevlendi ve Pithius'u evini kendisine satması için sıkıștirmağa başladı; Pithius güçlükler göstermeğe bașladi. Caniusun sonunda Pithius'u ev satmağa razı etmiş olduğunu sóylemeğe hacet bile yok. Tuzağa çekilmiş olan Canius, bu zengin adam Pithius'un istediğgi bedeli verdi ve hepsini toptan aldı. Bir mukavele yaptılar ve işi bitirdiler. Ertesi gün Canius dostlarıni davet eyledi ve kendi de erkence geldi. Denizin üzerinde en ufak bir tekne bile göremedi. En yakin bir komşudan malümat edinmek istedi: Acaba bugün balıkçlamn bayramı mıdır? hiç bir balıkçı görünmüyor; dedi.. Komșusu cevap verdi- Bildiğime göre bayramları olmamalı; zaten bu tarafa hiç bir balıkçı ge!mez. Ben de dün gördüklerime şaşmıştım» Canius tiksindi, fakat ne yapabilirdi. Meslektașım ve dostum C- Aquilius daha henüz hile hakkındaki talimatiamn formüllememişti (1). Kendisine hile nedir diye sorulduğu zaman bir şeyi yapar gibi gözükerek bașka bir şey yapmaktır, derdi. Yetkili bir adamın yapmıș olduğu doğru bir tariftir. Pithius ve onun gibi yapmacık yapanlar hilekâr ve namussuz kimselerdir. Yaptıkları faideli olamaz çünkü çirkindir.»

Ciceron ödevler 3.XV. - - Eğger Aquilius'un tarifi doğru ise hayattan bütün yapmacıkları ve saklamaları sürmek atmak làzımdır.

Satmak ve satın almak isteyen namuslu bir adam iși kârlı olarak bitirebilmek için bu gibi vasıtaları hiç bir zaman kullanmaz. Hileyi hatta kanun: XII lavha kanunu Tutela'da (vasinin hiyaneti halinde) tenkil ediyordu; Plaetoria kanunu küçüklere tuzak kurmayı tenkil ediyordu (2) ve nihayet davacı hüsnü niyeti ileri sürdüğü zaman mahkemeler için hususî kir metn ihtiyaç göstermezdi. Diğer başka yarğı işlerincle bazı formüllerin büy ük önem ve manası vardı. Böylece, ayrılmiş karı koca arasında bir mal taksimi halinde «iyi ve doğru olduğu miktarda» dive yazıhırdı. Bir vefa ile satıs, bir rehin mukavelesinde «namuslu adamlar arasında adet

(1) M. E. 66 senesinde pretör olan Caius Aquilius vargıçlara, hileye kurban edildiŏi bir sahıs tarafından iddia edildiği zaman, nasıl hüküm verecekleri hakkında talimat for. müllemiști

(2) Plaetoria K. (m. e: 192) 25 yaşindan aşă̆ı olan küçükterle bu vası asmıslar ara. sında fark vapiyordu ve bir küçüğün mağduriyetini mucip olan hileleri siddetle cezalandirıyordu. Küçüklerle vapılan sözlesmeler, Prețor tarafından tavin edilmiş bir kayvum tarafından incelenmedikce muteber tutulmıyacağını emretmişti. Bu emre aykırı hareket edilmesi halinde sikâyet etmek hakkı istisnasız surette bütün vatandasłara verilmiştir. 
olduğu üzere» (namuslu adamlarır istimallerine uygun olarak). «Iyi ve doğru olduğu miktarda formuiliu her hangi bir aldatmaya yer birakır m? ve «namuslu adamların istimalleri üzere» dendiği zaman hile ve kötui niyetle hareket edilebilir mi? Hile, Aquilius'a göre olmayanı var gibi göstermekten ibarettir. Binaenaleyh, bütün yalanları mukavelelerden uzak bulunduralım. Satıeı attırmayı kızıştırmak için sahı́ bir aỉei bulundurmama!ıdir. Alıc da, satıcinm karşisına bir sahte rakip dikmemelidir. Her ikisi de fiatı tayin ederken tek bir söz söylememelidirler (1) Quintus Scaevola satın almak istedigi bir arazinin fiatmm kendisine kesin olarak biläirilmesini istedi; satıe fiatı bildirdjŏi zaman Seaevola ken’lisine yaptığı fiat takdirinin daha fazla olduğunu söyledi ve bedele 100.000 sesterce daha ilâve eyledi. Bu tarzda ancak namuslu adamlarm hareket edebileceğinde kimse ihtilafa düşemez (2).

$\mathrm{Bu}$ hareket tarzinin namuslu adamlarm hareket tarzl olmakla beraber işlerini akıllıca gören adamların hareket tarzı olamayacağı belki söylenebilir; ve ma!ını değeninden aşağı satmış adama benzetilebilir. Iş̧te fenalıkta bu düşünüştedir. Doğruluk ile menfaatların akıllica idaresini birbirine zld iki key haline koyuyorlar: Bu hususta bir az fazla muktesid (tutumlu) diye şöhret bulmuş olan Ennius şunları söylemiştir : «ISendisine iyi hizmet etmeği bilmeyen kimse uslu bir ađam değildir.» ânnius'un bu sözünü tasvib edebilmem. için bir kimsenin «kendisine iyi hizmet eylemesi» tarzinda anlaşmış olmam lazımdır

Panetius'un bil talebesi olan Rodoslu Hekaton'un Tuberon'a ithaf eylediği eserinde șu sözleri yazmıs olduğunu görüyorum: «Yürürlükte olan adetlere, kanunlara ve müesseselere aykırı bir şey yaymamak şartile malına ihtimam etmek akıllılıktır.» Biz ya!nız kendimiz için zengin olmak istemeyoruz, çocuklarımız, yakınlaimız; dostlarimiz ve hususile devletin menfaati için zenğin olmak istiyoruz. Feldlerin gelirleri, servetleri devletin servetini vücude getirir. Hekoton ahlâklı Scaevolanın nakleylediğim hasbiliğini muhakkak ki zevkine göre bulmayacaktı. Çünkü serveti arttırmak usullerinden yalnız kznun ve adetlerin kabul eylemediklerini kabul etmejor. Bu düșünce de ise övïmreğe değer ve kendisinin sözlerinden fazla memnun olmakığımız icabettirir bir șey yoktur. Fakat hile yapmacik yapmak ve saklamak ise hilenin karræmadiğ pek az iș var demektir; namuslu adam; etrafına elinden geldiği kadar iyilik

(1) eSöz birl Allah birs Türk Ata sözü. \&Satıcı aynı sev hakkında iki muhtelif fiat istememelidir.s (Platon; kanunlar, XI, 917 b).Pazarliksiz satıs mecburivetine dair K: No 3489

(2) EAdamın iyisi alıs veriste belli olur.s Türk Ata sōzü

Hukuk Falkïltesi Mecmulasi : 20 
eden ve kimseye fenalık etmeyen kimse ise namuslu adam bulmi epeyce güçlük çekeceğiz. Netice olarak diyelim ki fenalık yapmakta faide yoktur namuslu adam olmak daima güzel bir şey olduğunłan ma faidelidir. $\gg$

Ciceron; ödevler; 3. XVI. «Gayri menkul mal larda mederî̂ ka: satıcının malın bildiği kusurlarını söylemesini emrediyor:

XUl lavha kanununa göre satıcı, yalnız alıcinin açık bir surette tığı sormalar üzerine verdiği beyandan türü sorumlu bulunuyordu; rumluluğu alıcının maluz kaldığı zararın iki misli idi. Hukukcularin hatları da kasten susmağı cezalandırıyordu (1).

Filhakika Hukukcular satıcının, gayri menkulde bildiği bütün surlardan, o kusurlar açıkca bilḋirmiş olmadıkça sorumlu bulunduj içtihat etmişlerdi... ...Caton'un hükmü, iyi velilmiș bir hüküm ol telâkki edilecekse buğday taciri ve sıhhî olmàyan evin sahibi sus. la ena hareket etmiş oluyorlar. Hisımlamian biri olan M. Marius tidianus, C. Sergius Orata'ya, bir kaç sene evvel kendisinden sati miș olduğu bir evi tekrar kendisine satmıstı. Lv, Oıatanin satmış ol zamanda o!duğu gibi satın aldığı zamanda da bir irtifakla mül bulunuyordu. Fakat Marius evi satarker bunu bildirmeğe lüzüm memiști., buna bilinen şeyi bildirmek denir ki abestir; fakat iș in mahal verii ve tribunala sevkedildi. Crassus Orata lehine, Antuavi Gratidianus lehine müdafaalarda bulunuyorlardi. Cassus dar hu dermeyan eyleyordu: "Satıcı bildirmediği bir kusurdan sorumlu Antuvan ise dar hukuka karşı nasafeti ileri sürüyor ve diyordu ki: gius bu kusuru bilmeyor değildi, çünkü evi bizzat kendi satmıștı. D ki ona iriifaktan bahsetmeğe lüzum yoktu. Orato da aldatılmamıştı. Ç satın aldığı șeyin hukukî vaziyetini biliyordu.» Ne için b: kadar veriyorum? Bizden evvelkilerin hile ve kumazlığı sevmediklerini termek için.»

Ciceron, ödevler 3, XVII. «Bir taraftan kanunlar; diğè tar filosoflar hileyi tenkil ederler; fakat tenkil tarzları ayni değildir nunlar positif (müsbet) tenkil tarzı kullanırlar, filosoflar ise ] karşı aklı ve zekayı koyarlar; Akı! hel türlü tuzak kurmaktan, he lü yapmacıktan, her türlü aldatmadan kaçınmağı emrẻer. Bir ạ mek, içine çekmedikten, içine itmedikten sonra bir tuzak kurm:

(1) Satılan malın tabiatina göre testim edilmesi asıl olarak (prensip olara mısłı. Eŏer avıp, alııının iși akłetmeden evvel göremiveceği vazivette ise ayıbı b mis olan satici sorumlu tutulurdu. 
saỵ̣lır denecektir. Vahşi hayvanlar bile bir avcı tarafindan takip e medikleri halde ıahi bir tuzağa dükerler. Bir evin satılık olduğunu i eyleyen lavha, içine bir ihtiyatsızın gelip düșeceği bir tuzaktan bai bir şeymidir? Bu hareket tarzl etrafı sarmus olan -ahlaktaki bozukd $\tan$ ötürü efkârı umumiyece takbih. edilmeyor; bu nareket tarzını nun ve içtihatlar cezalandırmayor; fakat tabiat kanunu (tabii hukı yasak ediyor. Çünkủ dediğim gibi - ki tekrarı asla fazla değildir. bütün insanlan en geniş bir cemiyette toplayan ve birleștiren bir 1 vardır. Halbuki aynı urktan olan insanlar arasinda daha dar bir bir vardır; ayni şehir (devlet) hemșehrileri (vatandașları) arasındaki lik ise daha dardır. Bu sebebten atalarmız gentium hukukunu vat; daşlar arasındaki münasebetleri tanzim eden medeni hukuktan aJ dilar. Medenî hukukun (jus civile) hükümlerinin hepsi gentium hu] kuna girmez; fakat gentium hukukuna ait olan hükümler medenî hui 'ka da şamil olmalıdır. Gerçektir ki som hukukun (halis, saí hukuku ve onun kızkardeși olan adaletin sert bir tunca dökülmüș resmine $(t$ : saline) malik değiliz; elimizde hukuk ve adaletin timsallerinden anc bir taslak vardır. Bari bu taslakin hareketimizi tanzim eylemesine t: I müisaade etsin. Bu taslağı çizenlere Tabiat ve Hakikat modellik etm tir. «Seninle ve verdiğin garanti ile zarardan emin olayım» gibi form lerin kıymeti çok büyüktür. «Namuslu adamlar arasında yakışık alır ؛ kilde ve hileden temiz bir tarzda» gibi formül ağırlığınca altın değer. dedir. Fakat namuslu adam denilebilecek adam!ar kimlerdir? Namuslu hareket etmek nasıl olur? Iște büyük mesele. Büyük keșiş Quintus Scء vole en ağır basan hükümlerin içinde hüsnü niyet tabiri en çok tatbi. mazhar bir tabir idi: vesayette, şirkette, rehinle ödünç almada (bir $q$ ibin işlerine ihtimam eylemeği iltizam ettiren bir akid olan) vekâlet alım ve satim da, icare-i âdemi de yani adam kiralamada (hizmet akdi yer kiralamada ve medeni hayatın bütün tasarruflarında tatbik edilir Akti yapanlar arasında çıkan bütün uyuşmazlıkları çözmek ve bütün 1 hallerde mes'uliyeti sinırlandırmak için çok kuvvetli bir fikir ve zekâ: malik bir yargıç olmak lazımgelir; hușusile ki daima mukabil efkârı hayatı bilmek, ihtiyatlı olmak gibi geçmek isteyen fakat bunlardan tam mile ayn bir şey olan tilkiliği muamele sahasını dıșına sürmek lâzar dix.

Hakiki ihtiyat iyi ile kötüyü ayırmaktan ibarettir; tilkiliğe gelinc eğer her bayağı hareket bir kötülük ise kötülüğü iyiliğe üstün kılan b haldir.

Tabii adalet duygusundan çımıs olan medenî hukuk hile ve ina 
kötüye kullanmağı yalnız gayri menkul satışlarında cezalandırmayor; kul satıșında dahi satıcının her çeşit aldatması yasak edilmiştir. Edillerin bir emirnamesi mucibince esir satan kimse sattığı esirlerin sıhhatinden, onların serkeșliklerinden, üçüncü şahıslar tarafından haklarında yapılan hirsızlık iddiasından ve bilmesi lazımgelen her șeyden sorumludur. Fakat kullar miras ile iktisap edilmiş olunca iş başkalaşir. Tabiat, hukukun kaynağı olduğuna göre tabiat, bir kimsenin bilmemezliğinden menfaat elde etmek için yapılan hareketleri tenkil eder. Hayatta, tilkiliği (hin oğluluğu) yüksek bir zeka olarak kabul etmek gibi bir felaket tasavvur edilemez; faideli ile ahlakın zaruretleri arasında var gibi gözüken ihtilafların kaynağı hep bu kötü kanaattir.»

14 - Ripert, eserinde hüsnüniyet hakkında șunları yazar: «ahlakî ödevlerin kanunî borçlara çevrilmesi cemiyet içinde adaleti egemen kılmağa ve yașatmağa kâfi gelmez. Bir kimseye zarar vermemek ödevi, ancak suçlu veya ihmalkâr bir iradenin hatal bir fiili netiçesinde zarar husule getirmis olması takdirinde müeyyedeye mazhar olur. Bu irade muntazam, usulünde yapılmış bir hukukî muamelenin içinde kalmıș bulundukça fiilin meșruluğu, kastin suçlu olması üzerindeki bütün tartıșmaları önlemeğe kâfi gelir.»

Bundan sonra Riper medenî kanunun kastlarla uğraşmayıp muamelerle meşgul olması ve böylece ahlak ile hukuk arasında keksin bir ayrılık yapmak lazımgeleceği hakkındaki düșünceleri; hüsnüniyetin mükafatlandırıldığı; hukukun istikrar ve emniyet istikametlerinde inkișaf eylemesine göre teknik usullerin muntazam bir tarzda kullanılmasinin muameleye itiraza yer birakmayan bir meșruiyet vereceğini iddia eden. lerin fikirlerini söyle anlatıyor:

«Bu sekepten insanın, ceza kanunu bile kasti; bir icra bașlangıcının bulunması halinde cezalandırınca medenî kanunun artık kasti bir tarafa bırakıp fiillerle mesgul olması lazımgeleceği kanaatine sapacağı gelir. Medenî kanun hukuk subelerinin emrine teknik şekiller ve kalıplar vermektedir; şubeler iradelerini bu kalıplara dökmektedir. Teknik șeklin muntazam ve usulünde kullanılması failin kastını korur ve meşru kılar. Ahlâk ile hukuk arasındaki fark muntazam bir fiilin, failin suçluluğu bahanesile iptal edilmesine müsaade eylemez. Kurnaz adam kanunun diș kenarnnda yaşamağı bilir. Hukukî telakki ile ahlâkî telakki arasındaki bu mutlak ayrılığa karşı hüsnüniyetin hukukumuzda işgal eylediği yeri göstermek suretiyle cevap vermek pek kolaydır. Bir çok hallerde kanun ve mahkemeler hüsnüniyetle hareket etmiş kimse ile, vaziyetinin ve ikti- 
sap sebebinin fesadını bilmesnden ötürü suiniyeti dolayısiyle daha fena muamele görmesi lâzım olan kimse arasında fark yapmaktadır.

Hüsnüniyetin hasıl ettiği neticelerin, kanuna uygun bir tarzda hareket ettiğini sanan bir kimseye mükâfat olarak verilmekte olduğunu ve bu mükafatlandirma fikrinin, suiniyet sahibinin cezalandırilmakta bulunduğu fikrine üstün tutulması lazrm geldiğini söyleyenler oldu. Fakat birini mükafatlandirmak haddizatinde diğerini cezalandırmak olacağına göre fark kpek fazla indîdir. Fazla olarak bu iddia doğru da değildir; çünkü hüsnüniyete bağlı neticeleri talep eden kimse, normal kakideye muhalif olarak hüsnüniyetini de ispat ile mükellef değildir. Çünkü hüsnüniyetîn vücudü asıldir (Türk M. K. Mad. 3).

Breton, hüsnüniyetin medenî neticeleri hakkında yazdığı bir makalede «Normal olan hukukî kaidelerin neticelerinin hüsnüniyet sahibi kimse olarak bertaraf edildiği» hususundaki. geleneğe uygun fikri müdafaa eylemektedir. Fakat normal kaide nasıl tarif edilebilecektir? Breton, hüsniyet ve suiniyet fikirlerinden mücerret olarak tatbik edilecek kaideyi normal hukuk kaidesi olarak kabul etmektedir. Ripert Breton'un bu telakkisine «taraflarin hareket tarzlarindan mücerret olarak bir hukukî kaide tasavvur edilebilir mi?» diye cevap vermektedir.

Pratilste suiniyetin Gezalandjelması gözuikmektedir. Suiniyetin isbatı, hukuki bir kaide ile iktisap ey!emis olduğunu sanan bir kimseyi hakkından mahrum etmektedir. Böylece normal hukukî kaidenin tatbik edilmesinin kabul edilmemesinde suç dolayısiyle verilmiş bir medenî ceza yok mudur? Bu vaziyet karşısında suiniyetle hareket etmiș kimsenin duismesi (sukut etmesi) veya ceza görmesi eski cezaî fikirlerin hala medenî hukukta yaşamakta olduğunu göstermiyor mu; ve acaba hukukun terakkisi bu fikirlerin atılmasından ibaret olmayacak mıdır? Medenî hulskukk ceza hukukundan ayrlacaktır ce bu ayrilma modern hukuk koyucusunun hukuk ile ahlâk arasında koymak istediği kesin ayrılığın ifade ve izharı olacaktır.

Hukuk telâkkisinin insanlar arasındaki münasebetlerde istikrar ve emniyet istikametinde gelișmesine göre yukarıdaki fikirler müdafaa edilebilir. Teknik șekillerin usulünde kullanışları faaliyete kusur izafe edilemiyecek bir şekil verir. Şekil, kasttaki kirliliği hımayesı altına almalıdır, çünkü içtimaî münasebetler görünüşe istinad eyler. Hukukî muamelenin faal olması nisbetinde emniyet ihtiyacı zaruret halini alır. Ahvali şahsiyenin ve hakların aleniyetinin tanzimi, șekilciliğin yeniden doğması, zahiri mülkiyet nazariyesi, müşterek hata hakkındaki eski düstürün mu hafazast emniyet arzusunun tezahürleridir. emniyetin ilmî bir tahliline 
lalizine) tevessül edildi. Demogue emniyeti statik ve dinamik (yani vazeneli bir halde duran ve hareket halinde bulunan) olmak üzere çeşite ayırdı. Emniyet kavramının bu muhtelif görünüșü, kavramın zşikliğini (mürekkep olușunu) ispat eder ve bununla da öne nini izhar er.» Ripert arz eylediğim mütalaaları şöyle cevaplandırma: adtr:

«Bu itirazlarda bir hakikat payı vardır Hukukî muamelelerdelki 'at ve emniyet bazen görünüșün gerçekliğe üstün tutulmasını icabettidaha doğrusu hukukî șeklin görünüşü altında ne gibi bir gerçeklik lunduğunu araștırmağı meneder. Bununla ahlâkın iktisada kurban edilsinin büyük bir zararı ve önemi olmaz. Ağır ve korkunç olan şey şek. bu zaferini göre göre insan, șeikli bir gerçeklik olarak almağa baş'or; șekil, ya hukukun sırf devletçi telakkisi yolu ile veya hukuk fikri1, faaliyetin intizamı inancına irca edilmek suretiyle gerçeklik olarak niyor. Bu zihniyetin tesirile sosyalist bir hukukcu olan Emanuel Levy rorki: «hukuk, hukuk olduğunu sandığımız șeydir.» Bu gibi düstürları ldiye almakla hukuku ancak genel bir. inanca istinad ettirmeğe varllır; ni fikrin garip bir sapıtması ve bozukluğu ìle hakikati müşterek hava istinad ettirmeğe varır.

$\mathrm{Bu}$ gibi telakkiler karşısında ticaretin ișlenmesi ugruna ahlakta fekârlık eildiği takdirde bu fedakâtrlıkların hepsi ahlâksızlığın zaferi ırak alınabileceğini iddia etmek lâzımdır. Binaenaleyh yapılacak fekârlıklar ahlaksızlığın zaferinin fazla küstah ve hașin olmamasile muyyettir. Bu fedakârlıklara ancak, fiiln adelete ve ahlaka-ayrılığı așkâr nadığı ve yalnız sanıldığ zaman müsamaha olunabilir. Fransız menî kanunu bize hukukî kaidenin ahlaki kaideye karşı üstünlüğüne mulif bulunduğuna dair misaller vermektedir: Beyyine olmadığı zaman mine müracaata müsaade eyleyor (1).

11) Boicların sukutu sebepleri arasinda müruru zaman da ver alir. Müruru zamanın kiki neticesi alacaklının dava hakkını düsürmesidir; borc duruvor, mutalebe kalkıvor jruru zamana uğrayan borc tabii borc olarak vasamakta, edava ohlivetini muhafazo nekte ve hattâ ikrar ile tekrar medenî borc halini almaktadir. Müruru zamano ubramis reun tabii borc olarak kalması vereceklinin ödemediğ bir vereceği vermekte vicdani ırcu bulunduğu kancatına davarır. Fransız medeni kanununda amelo ve hizmetçilerin scaklari 6 aylik bir müruru zamana tabidir; buna «kisa müruru zaman sistemi adi ve. ir ve istisnai hükümlere tabi tutulur. Adet olan bu iscilerin alacaklarinin derhal veril. zsi ve mukabilinde makbuz alınmamasıdir. Altı av zarfinda isfenmemis olan bu aleikların, vereceklisi tarafından ödenmis olduğu kabui edilir. Fransız medenî K. Mad. 2275 acaklıya müruru zamandan sonra dahi vereceklisine vemin tevcih etmesine müsaade ler. Böviece verecekli valnız müruru zaman definde bulunmakla kurtulamaz, hasmi erse vemin de etmeğe mecbur futulur. Ripert bu hali ikinci bir misal olarak zikreder. 
Medenî kanunun tekamülü asla kastin aramasinı bertaraf eylemeğe ttuf değildir: Bunun aksine ve tersine olarak denebilirki hukuk, hak jelerinin hüsnü niyetlerini nazara aldiğı nisbette tekamül eyler. Roma kukunun tekamülü de hüsnü niyet fikrinin tekamülü ile temayüz ey. aşitir. Isviçre (ve Türk) medenî kanunu 2 nci ve 3 üncü maddelerinde ? hakkın ve her bocun hüsnüniyetle kullanılacağını emretmektedir.

Bizim fransız kanunumuzda bu kadar geniş ve genel pensipler yok. "; fakat ahlâk fikirlerile yïklü ve hükukî șekillerin karanlk atölyesine slar demeti sokan eski darbimeseller: «kunaza müsamahakâr davranma!ıdır»; «hile he şeyi bozar, ifsad eder» ve nihayet «Dar bir tefsir büyük haksızlığa sevkeyler» hala Fakültelerde ve Adalet saraylarında 氵atılmakktadır. Yargı̨̧ bu düstüra yardım ile ruhların üzerine eğilir ve danlarn muayene eyler. Nasafeti hakim kılmağa çalıșır ve doğru olan afa kanunun verdiğinden fazla veremezsede ruçlunun elinden iktisap niș olduğunu sandığ hukukî vaziyeti alabilmek kudretini haiz olur».

15. - Profesör Sauser-Hall İstanbul Üniversitesinde Fransizca olas verdiği sekiz konferansın beșincìsini İsviçre Medenî $\mathrm{K}$. Hüsnü niyete sretmiștir. Sauser-Hall hüsnü niyet mefhumuna verilen büyük önemi rletikten sonra diyơr ki: «Isviçre Kanunu bu kavramı benimsemekle kukî tekamülün genel temayülünü takip etmekten başka bir şey yapmiştır. Yalnız Isviçre kanunu kavrama, diğer kanunların veremediki bir şumul, genel bir şumul vermiştir. Kavram en ziyade borçlar hukunda yer alır ve ödevini en müessir tarzda borçlar hukukunda görür. ansız hukukunda da böyledir; Kodsivilin 1134 incü maddesi «usulünde ekkkül etmiş mukaveleler onu yapanlar için kanun hükmündedir . ... snü niỵetle yapılmalıdır. der. Alman kanun koyucusu da hüsnü niyeaynı manayı vermekte ve medenî $\mathrm{K} .157$ inci maddesi «Mukaveleler, snü niyetin ve ticarî adetlerin icabettirdiği tarzda yorumlanmalıdır.» $\therefore$ Her iki kanun da, hüsnü niyetin tatbikini mukavelelere hasreylemişFiilyatta ise kazaî kararlar daha ileri gitmektedir. Isviçre kanun kosusu hüsnï niyete saygı prensibine derhal en geniş bir şumulu vermefaideli gördü ve pensibe bütün hususî hakları himayesi altında alabile: bir çevre verdi.. Isviçre ve türk kanun koyucuları tarafından hüsnü rete verilen önem pek büyüktür, positif hukukun hükümleri. her an : iște hüsnü niyeti emreyler. Binaenaleyh hüsnüniyetin hukukí manaI tesbit etmek lâzımdır. Ferdlerin servet ve şerefleri hüsnü niyet kavnının açıklanması ile doğrudan doğruya ilgilidir. Hüsnüniyetin hukukî ın açıklanması ilk bakışta gözüktüğü ve sanıldığı gibi kolay değildir. hakikat Almanyada 1860 ile 1870 arasında cereyan eylemiş ve gürül- 
tiiler yapmış bir davadan pek iyi anlaşılmaktadır. Bu şöhrete eren bu dava hukuk tarihinde Gollmeglin gayri menkulleri adı ile tanunmaktadır. Davada taraflardan birinin hüsnü niyetini takdir etmek lazımgeldi. Buna muvaffak olabilmek için altı fakülteden ve iki büyük romanist olan Waechter ve Bruns'dan istişarî mütalâalar almak lâzim geldi. Bu mütalâalar Modern doktrinin, hüsnü niyetin tayin ve takkdirinde gözüken iphamları kaldırmak için yaptığı mesaiye kaynak olmuştur.

Gerek Ísviçre ve gerek Türk medeni kanunlarında hïsnüniyet tabiri tarif edilmemiştir ve daima da aynı manada kullanılmıştır. Bu hakikat İsviçre med. $\mathrm{K}$ :nun Almanca metininden çıkmaktadır: 2 inci ve 3 üncü madelerde, fransızca ve türkçe metinlerde olduğu gibi ayni kelime kullanılmıştır. 2 inci maddede fransızca ve türkçe metin» hüsnü niyet «tabi. rini kullanır; almanca metin ise «vefa ve inanç» diye tercümẻ edebileceğimiz bir tabir kullanmıştır: «Treu» (sadakat, vefa) «und» (ve) «Glanbe» (vefaya inanma; verilmiş sözün tutulacağına inanma). M. K. nun 3 üncü maddesinde ise Fransızca, Türkçe, Almanca metinler aynı tabiri ktllanmakta birleşirler. «Hüsnü niyet», «bonne foi», «Gute Glauben» (1).

Binaenaleyh bu tabirlerden birincisi objektif ikincisi subjektif hüsnüniyet diye birbirinden ayrilıyor. Almanca «vefa ve inanç» tabirile ifade edilmiş olan objektif hüsnüniyet «doğruluk» demektir: herkez haklarını kullanmakta ve borçlarını yerine getirmekte doğruluğa, istikamete liayet ile kusursuz hareket etmekle mükelleftir. Kanun koyucusu 2 inci maddeye. her hak sahibini hüsnüniyetin icaplarından ilham almağa mecbur eden bir umumî ahlâk kaidesi ifade ettirmek istemedi. Yalnız hukukî münasebetlerde taraflarin uymağa mecbur oiduğu bazı istimaller (adetler) olduğuna işaret eylemek istedi; taraflar bu istimallere uymazlarsa ne haklarını kullanırken ne de borçlarnni yerine getirirken doğrudukla hareket etmiş olamazlar. Dernek ki medeni $K$. nun 2 inci maddesi, hukukî münasebetin çeșitine göre tabiatile değișen ve tarafların riayet eylemeğe mecbur bulundukları bazı kaidelerin vücudünü farz ve kakul eyliyor. Bu kaidelerin objektif varlıklari vardux; yani tarafla. rın iradeleri dışında ve iradeleri üstünde olarak mevcuttur. Bu kaideler taraflarin içinde bulundukları vaziyetten çıkmakta ve onları, adeta, istimale ve ticarî adetlere uygun bir harekette bulunmağa mecbur birakmaktad.r. Medeni K. nun 3 üncü maddesinde bahis konusu olan subjektif hüsnüniyete gelince, bu herkezin riayete meubur bulunduğu genel bir

(1) Gerçe nivet kelimesi fransızca «fois ve almanca «Glauben» in tam karşılı̆̆ deăildir. Foi, vefadir; niyet ise müstakim olmak, doğru olmak niveti masina göre «fois nin mukabili oluyor. 
ahlaklilik kaidesidir: Insanlarn hukukî münasebetlerinin temelinde bulunan ve o münasebetlexin esası olan genel bir ahlaklik kajdesidir. Insanların haklarının doğmasının, doğabilmesinin șartıdır. 3 üncü maddeye göre bir insan subjektif tarzda hüsnüniyeti haizdir. İkinci maddeye göre de objektif nüsnüniyet dailesinde, nüsnüniyet kaidelerine göre hareket eylemektedir. Bu iki çeşit hüsnüniyet ayrı ayrı şeyler olunca Prof. Gmür'un, meşhur olan şerhinde demiş olduğu gibi bir insan subjektif hüsnüniyete malik olmadan objektif tarzda hüsnüniyetle hareket edebilir veya subjektif hüsnüniyeti olduğu halde objektif hüsnüniyetten mahrum olabilir. Meselâ bir insan Çalınmış bir eșyayı bu gibi çalınmıș eşyalar satan bir mağazadan hüsnüniyetle niyetle alabilir. Fakat aleyhine, verdiği para kendisine ödenmek şartiyle (M.K. Mad. 902) istihkâk davası açıldığı zaman malí iade etmemek için yalan ve dolana tevessül suretiyle objektif hüsnüniyetten mahrum bulunabilir; iade borcunu hüsnüniyet dairesinde ifa etmekten kaçınmış olur.

Objektif hüsnüniyet - Objektif hüsnüniyetin adetlere, adap ve ahlaka, işlerdeki doğruluğa uygun bir hukukî faaliyet olduğunü söylemiștim. Bu hususta takikp edilecek kaidelerin hukukî münasebetlere göre değişeceği tabiidir. Fakat bu kaidelerin kanun tarafından teferruatile formülleştirilmemiş olmaları ve binaenaleyh kanunun dışında aranmalam lüzumundan ötürü onlarnn hukukî kaidelerden olmadıklarını sanmak hata olur. Bu kaideler, örf hukukunun kaidelerine eșittir; hatta bu laaideler, uzun bir istimal ile yerleşmiş bulunuyorlarsa hakiki örfü vücude getirirler. Bununla beraber 2 inci madde mezkûr kaideleri, ilgililerin onlara riayet eylemelerini mecburî kılmak suretiyle ve bu vasita ile medenî kanuna sokmuş bulunuyor; doğrudan doğruya olmasada yine de medenî kanuna sokmuş bulunuyor, vasita ile sokmuş oluyor. Böylece Isviçrede yalnız federal kanunların ihlal edilmelerini tetkik ile görevli bulunan federal mahkémesi, objektif hüsnüniyetin tayinine yarayan bir istimalin veya adetin ihlal edilmiş olmasının federal mahkemesi önünde itiraza mahal vereceğini değişmeyen ve yerleşmiş bir içtihat ile kabul etmektedir; çünkü bu kaideler, medenî $\mathrm{K}$. tarafindan zimmen kabul edilmiș bulunmaları dolayısiyle federal hukuk kaideleridir. Reichel, meșhur olan M. K. şerhinde «hüsnüniyete göre alınmış bir karar gerçekten bir hukukî karar olarak kalır» der. Objektif hüsnüniyete olan kaidelerin amacı kanunun metnini dùzeltmek değildir, sadece tamamlamaktır.

Objektif hüsnüniyeti müeyyede altına alan 2 inci madde yalnız, yargıçın hareket tarzını tayin etmiyor; bizzat taraflara da hitabediyor: Taraflar hukukô vaziyetlerini asla sui istimal etmemelidirler itidal ile ha- 
: eylemelidirler. Kanun, hükümlerinin olaylarla çakışmadığı, muka. erin haksızlıklar vücude getirdiğ zdakarlıklar yaparak bir anlaşma zemini araștırmalarını onlara 'azife kllyor. Bu vazifelerine riayet etmek istemeyecek taraflar mamalıdırlar ki yargıç, kendilerinin yapmadıklarını yapacak ve onbirbirine olan ilimadlaunın sarsılmamasıni koruyacaktir; bunun için ıçın bulup tayin edeceği doğru ortayı kendileri arayıp bulmaktan kataraflar bu hareketlerile bir șey kazanmış olmıyaraklardir.

Subjektif hüsnüniyet. â Sauser - Hall subjektif hüsnüniyete, bazı amn ve bazı olayların bilinmekte veya bilinmemekte olmasını farz mesi dolayısile asıl hüsnüniyet budur dedikten sonra șöyle devam ir: «Doktrin de şu noktalar tartıșmalıdır:

1) Subjektif hüsnüniyet bir insanm bir hak iktisap ederken bașkasıaakkkına zarar vermemekte bulunduğu kanaatinden ibaret midir?

2) Yoksa insanın bir hak iktisap ederken iktisabına engel olan bir vaziyeti sadece bilmemesinden ibaret midir?

3) Veya bu bilmemezlik ancak makul ve meşru olmak șartile mi hüsyete vücud verir?.

Almanyada uzun zaman üstün tutulmuş bir nazariyeye göre bir kima hüsnüniyet sahibi olarak telakki edilebilmesi için o kimsenin hiç hakkı ihlal eylemediği hususunda samimi bir kanaatı haiz bu1ası lâzımdı. Bu nazariyeyi «Pandek hukuku» adlı eserinde miidafaa ș olan büyük romanist Windscheid «usucapio» da hüsnüniyeti» bir senin eşyaya temellük etmekle kimseye karşı maddı hiç bir haksızrapmadığı hususundaki inançı» şeklinde tarif eylemişti. Reichel Is? mel: $K$. şehrinde bu noktai nazarı kabul etmiștir.

Fakat Savigny bugünkü Roma hukuku sistemi adlı eserinde hüsnüt kavraminı münhasıran menfi bir kavram haline getirmiștir. Bir senin hakkını iktisap ederken bu muamelesi ile bir başkasına zarar nediğine inanması lâzım değildir dedí; zarar vermekte olduğunu ce bilmemesini kâfi göruir. Savigny'nin bu noktai nazarı Bal üniversiProfesörü Wieland tarafından kabul edilmiştir. Wieland, Profesör ail Hakkı Karafaki tarafından Türkçemize çevrilmiş olan eserinde kiyetin iktisabma engel olan kusurlar bilmemek halinde hüsnünin bulunduğunu kabul ediyor.(1)

(1) Prof. Ismail Hakk. Karafaki Wieland'ın fikrini söyle nakledivor: «Hüsnünivet ba mani olan fesatları, hus'ssile noksan olan mülkiveti bilmemektir. Eğer iktisap kimse o sevin, mülkivori muhafaza kaydile mukayvet olduğunu biliyoridise hüsnüvoktur. (Ayn: haklar: I. inci k!sım: Mülkivet; kiinci basım 1947; mad. 714 ITürk M ad. 687) serhi sah. 340 ; d; bbl 
Uçüncü nazariye Alman kanun koyucusu tarafından açık bir tarzda edenî kanun gerekçesinde formüllendirilmiştir: $\$ 877$ inci madde isnüniyetten, mülkiyeti iktisap edenin onu ferag edenin maliki olmağı hususundakki, ağır bir hataya istinat etmeyen bilgisizliği gibi menfi $r$ hadiseyi anlamaktadir.» (Al.M.K. gerekçesi cilt III sah. 34 ( matlap: isnüniyet). Isviçre federal mahkemesi, içtihatlar ile Alman kanun koıcusunun noktai nazarını kabul etmiştir. Prof. Sauser - Hall medenî znununda Alman kanun koyucusunun koymuş o!duğu nazariyeyi kabul miş olduğunu iddia eylemektedir. Türk med. K. Mad: 932 suiniyeti şöytarif etmektedir: «bir aynı hak, tapu siciline yolsuz olarak kaydediliş ise, bunu bilen veya bilmesi lâzımgelen üçüncü șahıs bu tescile istiat edemez. «Bu tarifin mefhumu muhalifinden yani tersinden hüsnünietin tarifi çıartılabilir: hüsnüniyet, fili halin veya hukukî kusurun binmenesinin mazur görülebilmesini icabettirir. Gmur, meşhur olan şerinde «fiili bir vaziyeti, veya olayı kusurlu görülemiyecek tarzda biliemektir» diyor. Bilmemek bir hatanın neticesi ise hüsnü niyet mevcut maz ve ilgili kimse de suiniyet sahibi sayılır. Keyfiyetin Isviçre ve Türk edenî kanunlarında da böyle olduğuna, 3 üncii maddenin 2 inci flkra-

önünde şüphe edilemez: «ancak icabı hale göre kendisinden beklenen ‘timañı sarfetmeyen kimse hüsnü niyet iddiasında bulunamaz.» 3 üni maddenin zikredilen 2 inci fikrasına göre hüsnü niyet her hangi bir Irzda vaki dikatsizlik neticesi olarak zail olmaz; hüsnì niyetin zail labilmesi için insanın bütün vaziyet ve hareket tarzlarının, diğerleriin menfaatlerile ciddi bir tarzda ilgilenmediğini, kaygulanmadığını gösıren bir kayıtsızlığını meydana vurmasi lâzımdır. Hüsnü niyetin cail olallmesi için insanın, sarfedeceği ufak bir dikkat sayesinde, haklarını iksaba mani bir engelin bulunduğunu sezebileceği halde o ufak dikkati ile sarfetmekten kakçınacak kadar kayıtsız ve laubali olması lâzımłır.

Hüsnü niyetin bu menfi mahiyeti hüsnüniyetin lehine bir karine kaul ettirmiş ve suiniyetin onu ileri süren kimse tarafından isbat edilmeni zaruri kıldurmıștır. «Bir hakkın doğumu için kanunen hüsnï niyet urt kilinan hallerde asl olan onun vücududur.» (Mad. $3 \mathrm{flk}$. I). Hüsnüiyet lehine bir karine kabul edilmiş olması da pek tabịdir; çünkü ıenfi bir fiilin isbatı mümkün değildir denebilecek kadar güçtür. Halbui suiniyet madåi fiiller jcabettirdiğinden daha kolaylıkla ispat elilebilir. öylece gerek fiili ve gerek hukuki vaziyetin hakikatının bilinmesi vea bilinmesinin lazım olduğu hallerde hüsnü niyet zail olur; hatta nuakeme düşünüşe dayanan bir fikir elde edebilmek için vaziyeti ciddi 
tarzda ve bizzat incelemeği ihmal etmiș bir kimse de huisniu niyet yoktur.

Subjektif tarzda hüsnüniyet sahibi olan kimse mazur görülebilecek bir hatayı: fiili veya hukuki bir hatayı ileri sürebilir. Fakat ahvalin icabettirdiği dikkat ve basireti-her hangi bir sebeple göstermemiş kimsenin hatası, hafiflik göstermek veya kendisine fazla güvenmekten doğuyorsa mazur görülebilecek hatalardan değildir.

Subjektif hüsnüniyetin amacı Objektif hüsnüniyetin amaci gibi muamelelerde emniyeti imkân nisbetinde sağlamaktır. Bir ișe, kendisinden normal tarzda beklenilen dikkati, lâzım olan malûmatı alarak ve ihtiyatla hareket ederek emniyetle girmis kimse korumalidir; hatta iktisap ettiğini sandiğı hakta bil aksaklık olsa dahi korunmalıdır.

Kanun koyucusu tarafından hukuka böyle bir takyit yapılmış olması çok isabetlidir. Hukuki münasebetlerde umumî ahlak seviyesinin, yavașta olsa yine de emin bir tarzda yükselmesine hizmet edecektir. Kazai karalların hileyi, en son siperinde dahi takip eylemesi neticesi olarak iş adamları ve halk hüsnüniyet kaidelerine uymağı âdet edineceklerdir. Bu hususta Ord. Prof. Esat Arsebük.ün «Hekimlerin hakkı takdiri ve hüsnüniyet». (İstanbul 1927) adlı eserini zikrederim.

16 - Şimdi birazda hakkin sui istimalinden bahsetmek ve işe evvelâ Fransız görüșünün izahiyle başlamak lâzımdir.

Ripert hakkın suistimali nazariyesinin, ilhamını ahlaktan aldığını ve hukuk sahasına ölçülü olarak sokulmuș bulunduğunu söyler. Hakkın suiistimalini Fransız hukukcuları mesuliyet kaidesinin bir tatbik tarzı olarak kabu? ederlerse de Saleolles'in içtihadına göre mesuliyet kaidesinin tatbiki olmayıp hukukun genel bir prensibidir. Çünkï bir ahlak sahibini hakkından iskata ve binaenaleyh hakkını ahlaksızca kullanmış olan kimseye karşi sukutu hakkı tefhim etmekle objektif bir tarzda müsavi olan hakları nyrı ayrı muameleye tabi tutmağa varır. Imdi hakkın sui istimali yasağı bir mes'uliyet meselesi olmayıp hakların kullanılması sahasında bir ahlak prensibidir. Hakkını kullanırken bir kusur işlemiș bulunan kimsenin mes'ul olacağı ötedenberi kabul edilmiş bir esastır. Kusur, Romalıların «hakkını kullanan, kimseye zarar vermiş olmaz» şeklinde ve mecellenin de 91 inci madesinde «Hukukun caiz gordüğu şey tazminata esas olamaz» (cevazi şeri zamana münafidir), tarzinda ifade eylemiş olduğu prensibi gayri kabili tatbik kılardı. Kusur suçlu bulunan kimsenin hakkıını kullandiğını iddia edememesine imkân vermez. Mecellenin 92 ve 93 üncü maddelerinde bu hakikat daha güzel gözülkür: «mübaşir müteammid olmasa da zamim olur» yani herkes bir bașkasına, 
doğrudan doğruya yaptiğı zarardan dolayı mes'uldur; hatta o zararı istiyerek yapmıs olsa dahi; 93 üncü maddede mütesebbip müteammid olmadıkça zamin olmaz.» der; yani bir zarara bilvasita sebep olmuş kimse ancak kast ile, teammüd ile hareket eylemiș olduğu takdirde taź minat ile mükellef tutulur.

Medenî mes'uliyete ait nazariyenin tartışma konusu kılındığı bir zananda «hakkın sui istimali» formülü ortaya atıldı; bu formülü ortaya atanlar ayni zamanda medenî mes'uliyeti genişletrnek ve bunun için de mes'uliyetin temeli olan kusurun yerine riziko'yu koymak istiyorlardi (1). Riziki'ya dayanan kusursuz bir mes'uliyet ihdas eylemek için gayret sarfediyorlard.. Mes'ul edilecek olan faaliyet idi. Faaliyet ile zarar arasinda illiyet bulundukça faaliyet ika eylediği zararđan zamin olmalı idi. $\mathrm{Bu}$ iddia her hakkın kullanılmasını zimana munafi kılma sebebi kılamazdı. Insan, hakkını ne kakdar kullanır ise o kadar kuvvet iktisap eyler; ve kuvvet iktisap ettikçe rizikosu artar ve binaenaleyh mes'uliyeti artar. Bu mantıkî vaziyet güç müdafaa edilebilir. Hak. sahibinin az çok bir masuniyet elde etmek için yaptığı fedakârlık!ar nazara alınmamak suretile muktesep hakkın amelî faidesi yıkılmş olacaktr. Binaenaleyh hakkın kullanılmasında bir tefrik yapmak hür ve gayri mes'ul faaliyet sahasın tahdit eylemek lazımgelir.

$\mathrm{Bu}$ tefrik yapılınca da hakkın sui istimalinden, daha doğrusu hakların sui istimallerinden bahsedildi. Hakkın sui istimali yerine cemi olarak hakların sui istimali denmiş olması sebebi her ayr hak için ayr bir analiz (tahlil) yapmak mecburiyetidir.

Bu. fikir kolayca kabul edildi. Çünkü zimnen, XIX inci asır hukukcu• ları için pek kıymetli olan bir fikrin subjektif hakkın mutlak olması fikrini kabul eder. Bir insanin hakkını sui istimal ettiği zaman mes'ul ola. cağını ileri sürmek aynı zamanda hakkın kanunî bir sı̀nırı bulunmadiğinı ileri sürmektir. Hak, sınırını ancak kendi mahiyetinde ve sui istimal

(1) \& Kusur mevcud bir borcu yapmamaktır; bu yapmamak bir kimseve zarar ver. diăi takdirde tozmin edilmesini kanun emreder. Kusur, borç ile sıkı bir münasebet hal. dedir. Eğer bir kimse, yapmıs olduğundan dolavı mesul kılmak istenilen fiili yapmadan evvel bir sey ile mükellef değil idise Kusur bu olamaz. Binaenaleyh zarar vermek kastile haraket edilip edilmemiş olmasının önemi ve kıymeti yoktur. Bir kaç seneden beri hukuktan kusur kavramın atmak ve yerine Rizikoyu kıymak için cok kıymetli eserler vayın. land. Her kim bir baskasi için veni bir riziko, (tehlike) ihdas ederse doŏacak zarardan mesul tutulur.s Planiol Riziko nazarivesinin meseleyi olduău gibi çözülmemis olarak b!raktıăını ve cünkú su yeni rizikonun kusur teskil eden bir fiil, onu ihtäs edenin mesulivetini mucip olacak bir kusur olup olmadığını daima bilmek lâzım geldiğini» söylüyor. (Planiol Cild II No. 863) 
firi yardımı ile bulur. Meselâ bir malikin sui istamal ettiği zaman mes'ı olacağını kakbul etmek aynı zamanda malike her şeyi yapabilmek, ye kisini veren subjektif hakkı kabul etmek olur; Bundan sonra malik hakkını sui istimal etmemesi ile teklif ederek hakka, kendisini tahd: etmesi imkânı aranmış olur. Faaliyetin serbestçe yapılmasına konan k tahdit, hürriyet ve mes'uliyetin klâsik sahasında tasavvur edilniģ ol yor.

Hakkın sui istimalinin bu şekilde anlaşıldığı onu manasız bir ha atıyordu. Bu hususta Planiol'un şu sözlerini nakletmek kâfi gelir. «B yeni nazariye kâfi derecede incelenmemiș bị tabire dayanmaktadır. $\mathrm{Hal}$ kın sui istimal teşikil edecek tarzda kullanılması formülü bir kelime $\mathbf{g}$ rültüsünden başka bir şey değildir. Çünkü hakkımı kullanıyor isem fi lim meșrudur. Eğer fiilim gayri meşru ise sebebi hakkımı tecavüz etm ve haksız olarak işlemiş oimamdır. Binaenaleyh kelimelere aldanmama lâzımdır. Sui istimalin başładığı yerde hak sona emiş olur. Bu sebepte her hangi bir hakkın sui istimali bahis mevzuu olamaz. Çükü tek v aym bir fiil hem hakka uygun hem de hakka aykırı olamaz.,

Haklar mutlak olarak alınmazlar. Hakkın sui istimal edildiği mi şahade edildiği zaman çıkacak netice hak sahibinin, hakkının kullan masını sınırlandıran kanunî sınırlari aşmiş bulunduğudur.

Her kese, kusurile bir kimseye zarar vermesini yasak eden hukul kaide subjektif hakların sınırını teşkil eder. Bir kusur işleyen bu kaid yi ihlâl eder ve binaenaleyh hakkının dışına çıkar. Hakkını zaman nın ve muhitinin normal (tabii) şartları altında kullanmayan kims bașkasına yaptığ zarardan mes'uldür; çünkủ hakkın bu gayri tabii ku lanılması ile insanların faaliyet'erinin iștirakinden doğan muvazene br zulmuș olur. Gerçe fransz kazai kararları hakkın sui istimali tabiri il hakkın gayri tabii olarak kullanılmasını kastetmiyolar. Kazai içtihatl rın, hakkın bu gayri tabii istimalini medeni bir kusur olarak kabul e mekte olduklamnı kabul eylemek zarureti hasıl oluyor; çünkü medeı kusur her kesi başkasına zarar vermemek ödevi ile yükler. Bu ödev zi rar veren fiilin yapılması kolaylaştığı nisbette tavazzuh eder ve dah șiddetli olur.

Bu vaziyette yani, hakkın kullanılması hakkını kullananı gayri mes ul kılmayınca eski Romalıların «hakkını kullanan, kimseye zarar ve mi olmaz» düsturu ile fikihin «kimse, hakkını kullanırken yaptığ zq rardan dolayı mes'ul olmaz» kaidesi ne olmuş oluyor?.

Ambrois e Colin ve Capitant müste:ek olarak yazdikları eserlerind (cild II sah. 382) bu kaidelerin ilgasina variliyor dedikten sonra ey 
karıda yazıl kaidenin, ona bir kaziyenin (önermenin) keskin șide verecek gekilde yapılacak yorumu haksız ve manasız bir sonuça var tır; bizi medenî mes'uliyetin ilgasına sürükleyecektir. Insanın, kar açıkça yasak etmediği her fiili hakkın kul!anmasını teșkil ettiği : nemez mi:» diyor. Positif kanunlar tarafindan her ferde bilhassa miş medenî haklar» ile «insanın haklarını serbestçe kullanmasını yan bu genel haklar huzmesi» hakkında bașka tarzda hareket et mahai yoktur.

Burada dahi, mahiyeti itibarile sinursız ve ayn zamanda mes' kanunu ile sınırlandırılmıș olan subjektif haklara dair olan klasik riyenin hatırası gözüküyor. Ripert ise Roma düsturunun mahiyeti manasını şöyle anlatıyor: «Positif haklarm iktisadi kıymetlerini mak lâzımdır. Bu haklar bir fedakârlk veya bir çalışma sayesind hud bu fedakârlığı yapmış bir kimse tarafından devredilmek sureti de edilmiștir. Bu positif haklar belirli bir imtiyaz teşkil eder ve $\mathrm{k}$ sana diğer bir insan veya diğer insanlar üzerinde bir kudret verix demki hak vardır, demekki karşılık olarak bir borç vardır: ya belir vereceklinin borçu yahut medenî hakka saygı göstermekle mükellef ların borçları vardır. Hak sahibi diğer adamlardan, o adamlanı menfaatı için hareket etmeğe veya kendi faidesi için içtinap eyl€ (çekinmeğe) zorlamak suretile istifade eyleyecektir. Bu șartlar dair€ hakkını kullanan kimse, hürriyetini kuliandığını iddia eden kim daha fazla bir sorumsuzluk isteyebilir. Hakkın kullanilmasinda s suzluk duygusunu jfade eden Roma Kaidesinin manası bundan ibas $\mathrm{Bu}$ sorumsuzluk serbest ve korkusuz bir faaliyet zaruretine istinat o faaliyetin sınırlarını bu zarurete göre tayin etmek kanun koyuc ve yargıça aittir. Hak sahibi kudreti dolayısile faaliyetinin şiddetin turdığı taktirde kazai içtihatlar da bu zararli faaliyeti daha fazla s le durdururlar. Böylece büyük endüstri müesseselerin:n işletilmesi ten malikin mes'uliyeti hakkında mebzul içtihatlar vücude getirm

Planiol de hakkın sui istimaline dair olan tartışmalardan çı: ni neticeyi şöyle bildiriyor: «Insanların kendi haklarının şumulü, liği hakkında besledikleri kanaatlarda önemli ve daimi değișmeler olmuștur. Vaktile mutlak gibi gözüken filan hak mutlak olmakta mıştır; az takyide uğramakta olan başka hakda da takyidler arttır tır» (cild II No. 871).

Ripert hakkın sui istimali tabirinin hakkın kullanmasından । mes'uliyeti ifade eylediğini bildirdikten sonra sahasını şöyle tayi yor ve diyorki: Bir hak sahibinin faaliyetinin, hakkın normal ku 
ması telakki edilebilecek şartlar dahilinde cereyan etmiș olduğunu farzedersek mezkûr faaliyet bir kimseye zarar vermis bulunsa dahi hak sahibinin «hakkını kullanan, kimseye zarar vermiș olmaz» kaidesinin himayesi altına girmiş bulunduğu da kabul edilir. Fakat hak sahibinin fiili bir diğerine zarar vermek kastım taşımakta ise ve ilhamm bu kastan alyyorsa zarar vermek kastı fiilin mahiyetini değiştirir. Saleilles der ki: «neticesi, yapan için meşru ve hissedilir bir menfaat sağlamaksizın başkasina zarar vermek olan bir fiil asla bir halkkin kullamlması olarak kabul edilemez.» Böyle bir fiil hakka aykırıdır; onu hakka aykurı kılan şey de «kastî olan gayesinde mündemiç (bulunan) ve cemiyet hayatını bozan mahiyettir. Yine Saleilles «başkasının menfaatına zarar vermek fiillerimizin meșru bir neticesi olabilir, fakat asla meşru bir saiki olamaz.» Saleilles'in bu fikri ve tezi parlak bir muvaffakiyete erdi. Planiol bu fikra ve teze karşı koymakta yalnız kaldı; «fikir muhakkakki asıldır fakat doğrumudur,» dedi. Planiol'un zarar vermek kasti hakkındaki görüșlerini aynen nakledelim: «Meşru, haklı bir riilin (hakkın istimalinin) gayri meșru, haksız bir fiil (hakkın sui istimali olabileceğini kabul eden müellifler bu sonuça zarar vermek kastına müsamaha edilemiyeceği kanaatlarından dolayı varmışlardır. Öyle ise hakiki bir menfaat olmaksızın, meșru bir sebeb bulunmaksızın, mahza bir diğerine zarar vermek kastile kullanılan bir hak suç oluyor ve failinin mes'uliyetini intaç ediyor. Bu alicenab fikir acaba doğru mudur; Insanlar ömürlerini birbirlerine zarar vermekle geçirmektedirler. Cemiyet hayat daimî ve evrensel bir cidaldir. Her faaliyet, her çalışma iktisadî ve içtimaî bir rekabetin fiilidir. Faaliyetinin her hangi bir şubesinde üstünlük elde eden her adam, her millet diğerlerinin yerine geçer, onlara zarar verir ve onlara zarar vermek hakkıdır (1). Tabiatın kanunu budur ve insanlarin bu kanundan siyrılmak istemeleri menfaatlerine uygun de ğildir; çünküi insan enerjisinin tek muharrikidir. Başkasının zararına olarak muvaffak olan kimsenin bahtı kara rakiplerini tazmin etmesini istemekliğin mümkün olamıyacağı aşikârdır:.. İçtimaî ve iktisadî rekabetten doğan zararli fiillere kanun tarafmdan, fiillerle zararın istenmiş olup olmadğı araştırılmaksızın müsaade olunmaktadır; çünkiu başkasina zarar görnnemesinden kaçınılmasına imkân yoktur. Ancak grevlerde gözüktügüü üzere șiddetli vasitalar ve gayri kanunî rekabette görüldüğü üzere hileli muameleler gayri meşrudur.» Ripert, ferdiyetçi na-

(1) $O$ gün için kâfi derecede alıs veris vapmıs olan eski zaman türk tacirinin gel. mekte devam eden müsterilerini o gũn kâfi derecede is yapmamıs komsusu dükkâncıya (vani bugünkü tabir ile rakibine) gönderdiŏi anlatilır. 
zariyenin mümessili olan Planiol'un tabiat kanununun daimî savaș illduğu kanaatine şu güzel mülahaza ile cevap veriyor: «Planiol'un, insan kanununun bu hodbin (benjil) faaliyetlere adalet fikri önünde baș kestirmesi lâzm değilmidir diye viculanına sorması Ripert'in bu cevabı ferdin, cemiyet mefhumuna başkesmesi, yani inkiyat etmesi lâzım geldigini gösterir.

Yapılmı̣ bir zarar ve zarar vermek kastı önünde müellifler bir medenî mes'uliyetin bulunduğuna hüküm ettiler. Zarar vermek kastı ya yapllmı fiilin anormal mahiyetinden çlkarilmakta ve binaenaleyh klasik telakkiye göre kusur meydana gelmekte, yahut fiilin hudusuna munhasıran failinin (mübaşirin) sebeb olmuș bulunmasını meydana çlkartmasından zahir bulunmaktadır.

Objektif mes'uliyet nazariyesi arasında yerini almış olan hakkın sui istimali subjektif. mes'uliyet nazariyesi arasinda da yer aldı. Fransiz Medenî kanunun muhteviyatının Fakültede okunma senelerine göre yaplan tevzi ve taksiminde hakkin sui istimali bahsi bu yerini muhafaza. eyledi. Fakat hakkin sui istimaline bu yeri muhafaza etmekle, onun mahiyetini bozmak ve zayıflatmağa varlur. Haksız fiilden doğan mes'uliyet bir zararın faili, diğeri mağduru (kurbanı) olmak üzere iki kişiyi karş karşıya getirir; bu iki kişi tazmine esas olan fiilden evvel, bir birile hiç bir hukukî münasebetle birleşmemişti, veya hiç olmazsa, tazmini mucip fiilin konusu bulunmuş olan bir münasebetle birleșmemiști. Eğer tazmini mucip fiilin faili, fiilin zarar vermiş bulunduğu kimseye karşı fiilin yapılmasından evvel vücude gelmiş bir borç ile borçlu bulunuyor idise o zaman mesele değişir ve mes'uliyet, mukave!eden doğan mes'uliyet adını alır. Eğer magdur faile karş borçlu bulunuyor idise yine mesuliyetin mahiyeti değișir ve hakkın sui istimali meselesi doğar. Eğer zarar veren fiilin faili bir hakkın sahibi ise magdurun zarara katlanmak borcu var demektir ve binaenaleyh yapılmı zarar tazmine esas olamaz; çünkü zarara uğrayanın o zarara şikayet etmeden katlanmak borçu vardır. Mes'uliyet meselesine varabilmek için evvelemirde hakkın sui istimali meselesini haletmek lazımdır. Saleilles yazll bir kanunun ilk maddelerinde, evvelâ umumî intizama taalluk eden kanunlara muhalefet edilemiyeceği kaidesini koyduktan sonra kimsenin hak!ar'inı sui istimal edemiyeceği kaidesini koymak lâzımgeleceğini hakkile iddia etmişti; bu çifte kaide faaliyetleri sevk ve tanzim eden iki prensibtir.

$\mathrm{Bu}$ telakki tarzı esasa ait bir hal tarainı icabettirir. Mesele yalnız hakkın kullanılması sırasında yapılmıs ve kasten zararl olan fiilin vucude getirdiği zararı tazmin ettirmekten ibaret değildir; mesele böyle 
bir zarar vermek kkast ve niyeti kendisinde bulunan fiil ve failin kanunun kcrunmasına mazhar olup olamıyacağını tayindedir. E'ğer zarar vermeis kastını taşıyan bịr fiili kanun korumuyor ise o fiilin imkân nisbetinde önlenmesi lazımgelir, önlenmekte geç kalınmış olunca neticelerini, aynen tazmin suretile yok etmek lazamgelir. Hakkn sui istimali meselesinin bir medenî mes'uliyet meselesi bulunduğu fikri ileri sürülerekten aynen tazmin fikri tenkide uğramıș ise de Ripert vaktile katılmșı bulunduğu bu fikirden geri dönmüștür. Fiilin icrasının önlenmesi ve aynen tazmin usulleri normal bir müeyyede olarak kullanılmaktadır. Binaenaleyh fiil önlenemeyipte teaddi, muhalefet ve mugayeret bir emri vaki olunca ve tamir kabul etmeyince, iște o zaman zarar ve ziyan bahis mevzuu olur.

Planiol Alman K.nun «hakkin kullanılmasının, sırf başkasına zarar vermekten bașka bir kastl yok ise o hakkin kullanılmasına izin verilemez» deyen 226 incı maddesini anlatırken diyorki: «zarar vermek kastı hattı zatında gayri meşru olduğundan her hangi bir hakkın, zarar ver. meği hedef tutan kullanılmasını da gayri meșru kllar. Ilk bakıșta, ahlàki temayülü ile tatmin edici gözüken bu kaide ya ölü bir söz halinde kalacak, yahut çok güç tatbik edilebilecektir. Filhakik? hakkın kullanılması antisosyal (cemiyetciliğe aykırı) olmak itibarile reddedilmek için bașkasina zarar vermekten başka bir kast güdmemelidir; fakat fiilin faili ayni zamanda kendi için șahsi bir menfaat elde edebilirse hareketi meșru olur; çünkü aksi taktirde hem her hangi bir hakkın kullanılması imkânsız hale getirilmiș oiur; hem de ticaret hayatı, rekabet, içtimaî terakki, insan enerjisinin gelişmesi buna bağlıdır. Demek ki yargıç vicdanlari yoklayacak, saikleri bilecek ve tartacak o zamandz ișin pisikolojik tarafı üstün kılınmıs olacak. Medenî mevzuatın, bașarılnaası kudret ve kuvvetinin üstüne așan bir ișe girișmiș olmasından korkulur.» (Planiol cild II No. 875 bis).

Planiol'u temine uğraştılar. Saleilles fiil antisosyaldir dedi. Josserand malik, mülkiyetine antisosiyal bir istikamet vermiștir dedi. Kullan!lan tabirler yanlıș değildir; fakat gayri kâfidir. Fiil ne için antisisiyaldir; ayni fiil aynı zararı hasıl ettiği halde meșru telakki edilebilir.

$\mathrm{Bu}$ filler arasındaki sosyal (içtimaî) kıymet farkını sırf, faili hare kete getiren kast vucude getiriyor. Demek ki içtimaî (sosyal) fiiller, hat. ta hukukî noktai nazardan dahi ahlaki kıymetlerine göre tasnif edilmelidir. Pr̈ofesör Savaier diyorki: «Hakkın sui istimaii bize hukuk ile ahlâk arasındaki bir ihtilaf gibi gözükmektedir. Yahut, daha açı olarak deyelim ki bir șahsa ait positif bir hak ile o şahsi yükleyen, o şahsa ait 
bir ahlâk ödevi arasında bir ihtilaftır; mezkûr şahıs hakkını kullanmakla ahlâki vazifesini yapmayor.» Gerçektir ki ihtilaf buradadır. Başkasına, haincesine zarar vermemek hususundaki ahlakî vazife, acaba hak sahitinin elinde hakkmı ne derece ifna, yok edebilir?

Yargıçın kötü kastı kabul etmesi lâzımdır. Kastın araștırilmasi acaba güģlük gösterir mi? Gösterse bile hüsnü niyeti ve kanunun ruhuna muhalefeti araştrmaktan daha ziyade keyfi olamaz. Surf objektif bil medeni hukuk yaratmak ve fiilleri, kast ile mesgul olmaksızm takdir etmek ham bir hayaldir.

Her halde mesele açlkça ortaya konmuș ve tabirin manası meydana çıkartılmıştır.

Sauser Hall'in İstanbul üniversitesinde verdiği konfertanstan dördücüsünde hakkın suistimalinden bahsedilmiș ve orada fransız cereyanları çok güzel hülasa edilmiştir. Mezkûr konferanslar türkçeye tercüme edilmiș olduğundan oraya müracaat olunabilir.

17. - Alman medenî $\mathrm{K} .226$ inci madesinde «hakkın, bașkasına zarar vermekten başka bir amacı bulumayan kullanılmasına müsaade edilemez.» denmistitir. Alman medenî kanununu tercüme eden büyük fransız alimlerinin mezlkûr madde altına koydukları nota göre yeni kanunların farikasını bu maddeden daha iyi tayin edecek bir șey yoktur. Modern hukukun, kendisini git gide daha fazla tevdi edeceği cereyan, bu maddeden daha iyi gösterecek bir șey yoktur. Alman medeni K. bu madde ile ahlakın sahasına tecavïz etmeği istemiyor; yargıça, hakkın muh tevası içine giren șu veya bu yetkilerini kullanmağa ilgilileri sevk eden şahsi saiklen takdire müsaade eylemeği istemiyor. Fakat bir hakkın muhtevasınin asla hududsuz olmadiğını ve hudutlarının geniṣliğinin içtima- ahlak hakkındaki telâkkilere bağlı bulunauğunu prensip itibarile ifade etmek ve prensip olarals koymak lâzımdır. Hukuk ferdî alak ile karıșmayor, yani hukuk ahlakin bütün istcklerini israrla istediklerini teyid eylemiyor; Fakat hukuk, içtimaî ahlakın istéklerile ihtilafa düșemez: âmme vicdanını tahrip etmeksizin ihtilafa düșemez. Hukuk, adetlerin âmme ahlakına teaddi olarak telâkki eylediği şeylere, cemiyet için. de yașamak haline zıd olarak (antisosyal olarak) gördüğü șey!ere müsaade edemez. Bu itiba: la 226 inci madde içtimaî tesanüd telakkisile ahengi gerçekleștirmiștir.

Planck, bundan, hakkın sui istimalinin 226 incı maddenin anladı̆̆ manadaki tarifinin, haksız fiilin 826 noı madde gereğince ahlaka aykırı 
olması telâkkisile aynı olması lâzımgeleceği neticesini çłkarttı (1).

226 ve 826 inci maddelerin hemahenk klınmalär bir hakkın meşru istimaline girebilen bir fiilin mahza adetin red ve inkâr eylediği usul ile başkasına zarar vermiş olmasından ötrü aynı zamanda do bir medenî suç teşkil etmesini mutlaka istemiş olmak değildir. Bir fiil aynı zamanda hem caiz hem gayri caiz: hem meşru hem gayri meşu olamaz. 1ki maddenin hem ahenk kilinmasından maksad sadece hakkin istimali olan bir fiilin bir medenî suç ta teşkil edebileceğidir fiil hakkin sui istimalini teskil edeceirtir. Filin hakkm sui istimalini teşkil eden unsurların yalnuz 226 incı madde tayin etmektedir. Iki madde arasında sahayı iyi tahdit edebilmek için hakkın muhtevasıni aşan fiil ile hakkın kötii kullanıșunı ayırmak lazımgeldiğini teklif ediyorlar. Birinci takdir de 226 inci madde ikinci takdirde 826 inci made tatbik olunmalıdır diyorlar. Her iki madde arasındaki, münasebet ihtilaflarını o bitmek ve tïkenmez münasebet ihtilafların, yani 826 inci maddenin 226 inci maddenin mecburi bir tatbik tarzı olup olmadığı veya 826 nncı maddenin 226 ya girmeyen fi-

(1) Madde 826. «Kasten bir baškasına ahlâka teaddi teskil edecek tarzda zarar veren kimse o baskasına karsıı zaranı tazmine mecburdur.s Tazmine esas olacak fiil iki tülüdür: biri hukuka aykıı fiil, diğeri hukuka aykırı olmasa da ahlâka aykırı bulunan fiil. Hakkın ahlaksız kullanışı valnız hakkın suiistimalinde mi bahismevzuu olabilir, yoksa hakkın suiistimalini teskil ermivecek bir fiil ahlaka teaddi teskil etmez ve binaenaleyh 826 ınc maddenin tatbikine mahal vermez mi? Alman yargıtayı içtihatınca hakkın sui istima. li 826 inci maddenin tatbikini takyid eylemez. Hakkın, 226 incı maddeve göre caiz olan kullanması 826 inci maddeve göre tazmin mükellefivetine vücud verebilir (R. G. 58, 216).

Madde 138. - - «ahlâka aykırı olan bir hukuki muameie batıldır» Alman medenî k. nun işbu 138 inci maddesi bir hukukì muamelenin ahlaka aykırı olarak vasiflandirıla. bilmesi için yargıçı o fiilin, ahlaka avkın bulunduğunu farik kılan bütün unsurlarını tah. lil etmek vetkisin haiz buiunduğunu farzettirir. Binclenaleyh vargıc bir muamelenin ah. icka avkır buiunduğuna hükmedebilmek işin o muamelenin, hukukî muhtevası içine giren ve hatia dısinda kalan bütün unsurların tahlil edebilmek vetkisini haizdir. Yargıç takdirinin ithamini muamelenin saikinden dahi alabilir; valnız saiki muamelenin gayri ahlakiliğine hükmetmek için nazara alınmasına adetin müsaade evlediği nisbette nazara alabilir. Cünkü adet ve istimallerden çikartilan farikalar (kriteriumlar) yalnız filin ahlaksız vasfinı verdiren unsurlan da tayin ettirir; onları farikalari ile tayin ettirir.

Bu hukuki muamelenin su veva bu unsurunun gayri ahlâki olduğunu yargıı̆ın hangi telakkiye göre tayin edeceğine gelince denebilir $k i$ vargıc cari adetlere göre tavin edecektir. Fiilin ahlaksızlık vasfı ve farikası |kriteriumul her hangi sivasî, felsefî? dinî bir telakkiye göre tavin edilmeyip adetien ve teamüldeki telakkilerden hülasa pratikten cıkartılmalıdır; umumî adtlrin genel cerevanından sıkartılmalıdır. Fakat sanılmasın ki vargıs pratikte cari olan, yayılmıs bulunan seyleri müsahede ile kanicakıı, vani adefle. re cari oldukları sekilde riavet edecektir. Havır, vargıı umumî efkârın, akdin veva daha genis bir tabir ile hukuki ișlerin, ahlâk hakkındaki telakkilerine uyoun dósmesi hususundaki görüslerine ve isteklerine iltihak evleyecoktir. 
iller hakkında da dermeyan edilip edilemiyeceği hususundaki ihtilafları bırakup hangi fillerin 226 mcı madde mucibince gayri meşru olacakları$\mathrm{nl}$, yani hakkın sui istimali olacağını tayin etmek lâzımdır.

$\mathrm{Bu}$ hususta Planck en dar bir tefsiri teklif eylemektedir. Planck diyor ki 226 inci maddenin tatbiki için hakkn istimalinin ahlaka aykirı olması kâfi değildir; çünkủ ahlaka aykmılık 826 inci maddenin kullandığı formüle girer. Hak sahibin zarar vermek kastını güdmüș veya zarar vereceğine şuur hasıl ețniş olıası da kâfi gelmez. Cünkü bir insan her hakkunı kullanışta, hatta o kullanmayı en meşru hudutlar içine de alsa yine de başkasına zarar vereceğini bilir. Planck daha ileri giderek hakkın kullanan kimsenin, bu kullanmakdaki kastınm sirf zarar vermek olmasının da kâfi gelemeyeceğini söylïyor. 226 inci maddenin lafama göre hałkkın kullanı.lmasında zarar vermek kastından başka hiç bir kast bulunmaması lanm geleceğini söyleyor. Çünkü hakkın kullanılmasında zarar vermek kastından bașka bir kast daha mevcut olunca fiilin sirf zarar vermek kastile yapılmış olduğunun, psikolojik araștırmalarla meydana çıkartılmasını kanun kabul etmemiştir. Binaenaleyh fiile kötülïkten başka bir gaye objektif tarzda verilemenelidir. Işte Planch'in düşüncesine göre 226 inci ve 826 inci maddeleri birleștiren bu okjektif táriflerdir. Kanunun, objektif bir tarzda kötü niyetten başka bir şeyle izah edilemiyen fiilin $826 \mathrm{mcl}$ madde mucibince ve zarurì bir tarzda ahlaka aykur olduğunun ve bu itibarla sui istimal ve gayri meşru bu lunduğunun kabul edilmiș olrnasını istemiş olması belki münkündür. Fakat ahlaka aykırılik ve hakkın sui istimali kavramlarını bu nevi fiillelere hasretmiş olmasının istemiş bulunduğunu kabul etmek güçtür. 826 inci maddenin ifadesindeki genişlik onun tatbikinin genişlemesine mani olunmağa hiç imkân vermez; diğer taraftan bir fiil ehemmiyetsiz ve çok kủçük iktisadî bir menfaat sağlasa dahi başkasina zarar vcrmeği, âdetleri müteessir edecek șekilde kast eylediği takdirde yargıcın o fiili gay. meşru olarak beyan etmesine nasıl mani olunabilir? Böyle yava ş yavas adetlel, yani içtimaì ahlâk subjektif haklarin muhevasının son had. dini ve farikasını (kreteryomunu) tayine varacaktru.

18. - Isviçre hukukuna hakkın sui istimali dokţrininin oluşu üzerinde fransız ve Alman nazariyelerinin müessir blunmus olduğu Sauser Hall, bahseylediğim konferanslarında bildimiştir.

Sauser - Hall'in Türkçeye tercüme edilmiş olan bu konferansını oku mak mutlaka lâzımdur.

Perrochet, hakkun sui istimali hakkmdalki tezinde formülleștirilmiş olan hukuk ile hakiki hukuk arasındaki ihilafların göziikmesi olan 
hakkın sui istimali meslesini (problemini) şu șekilde taif etmektedir: «Bir subjektif hakkın, görünüşte kanunun o hakka cizdiği s’nirlar için. de kullanyş, bazı hallerde fazla ve ifiat gibi telakki edilemez mi, ve bu itibarla kullanan akkında, kullanışına son vermek ve vermiș olduğu zararı tazmin eylemek borçu doğamaz mı?» (sah. 228).

Hakkın sui istimali nazáriyesi hakkın normal kullen!șina taalluk eder. Eski kanunlarda hakların kullanılması hakkinjaki mutlak noktai nazara içtimaî hayatın gelișmesi dolayısiyle artık bugün hakkm gayesine uymayor, takibedilen içtimaî gaye ile hemahenk olamıyor. Hukukun iç biinyesi daha fazla tevazzuh ettikçe, hususile formülleștirilmiş olan po sitif hukukun kararsız!'ğl daha iyi anlaşlldıça onun dar tefsirinin ta. kip edilen genel gaye ile açlk bir tezat haline düştügü görürükçe sab jektif hakların son haddine kadar götürulmesinin sui istimal tesckil et tiği daha iyi anlașllyyor.

Fakat formüliestirilmis hukuk; her subjektif hakkin kallanlması nun sinırın doğru bir tarzda tayin edemediğinden mnaklarm kullanı!masına ait farikayı belirtecek metodu ifade etmek lazımdir.

Formülleștirilmiş hukukun, formül!eșme zamanmùa hakiki hukuka. ait olarak telakki edilebilecek olan bazı hüliümleri, ı̣timầ fikirlerin geliģmesi yüzünden hakiki hukuk alanından çkmalnta ve gayri miessir bir hale gelmektedir. Fakat kanun koyucusu tarafindan de. ğiștirilmedikçe bütün kuvvetlerini muhafaza edeceklerinclen bu hükümlerden doğan subjektif haklar da eski formiil dahilinde kullanılmakta deva meder. Fakat hakkın, devam eden kullanılması artık hakiki. hukuka uygun değildir, yan: takip edilen içtimaî gayeye uygun değildir. Demek ki hakkın formülleșmiş hukuka göre kulanılması ile hakiki hukuk arasındeki ahenìsizlil içtimaî fikirlerin, âdetlerin tekamülünden doğmaktadır. Hakkin zarar vermek kastile kullanimasinda ihtilaf, hakkinı kullanen kimsenin hakkının gayesi hakkındaki yalnı dụşünüșünden doğar.

Hakkin sui jstimali meselesinin, esasm:, cevherini positif hukuk jle hakiki hukuk arasindaki bu ihtilaf vücude getirir. (Perrochet sah. 232). Karl Huber'e göre hakkın sui istimalini, formülleştirilmiş hukuk ile hakiki ukuk arasındaki daimî ihtilâf fậık kılar. Binaenaleylı bu kanaate göre hakkın sui istimali nazariyesi ku ihtilafı kaldırmağı yok etmeği he. def alır. Hakları hakiki hukuka göre yani takip edilen içtimaî gayeyo göre kullandıracak bir genel formül bulmak lazım geliyor. Bu bnlunacak formül mevzu hukuka (positif hukuka) üstün olma!ı ve binaenaleyh onun gelişınesine tabi kinnmamış bir anme intizamı prensibi teşkil etmelidir. 
Bu prensip Stammler'in dediği gibi hukukun ana kavramını teșkil edecektir. Bütün hukukî iradelerin ödevlerinin gayesini teșkil edecektir. Einaenaleyh hakkın sui istimali doktrini hukulkun sınırlarını tayine çalı̧ır; hakkın kullanmasınin yalnız kanunun lafzina uygun düșmeyip daima hakiki hukuka uygun olmasını sağlamığa çalıșir.

Hukuk insanın çeșitli fariliyet sahas:nı tahdit ejer; Içìmaî nizama uygun ve kendisinin düzenlemek ödevi olan faaliyetlerin sahasına gireni ve bu sahanın dıșında kalanı bildirir. Hukuk hak sahiblerine rehberlik edecek sinırları tayin eder. Bu sınırlarda inkita (kesilme) olmayacaktır, objektif hukukun rolü bundan ibarettir. Binaenaleyh, Stammler'e göre hukukun her kaidesi asağıda yazllı üz meseleyi halletmeğe mecburdur:

1. - Kanun koyucusunun bir hak hakkındaki ielakkisi nedir? Yani akkın rolü nedir; içtimaî nizama karșı görevi nedir?

2. - Rolu aranlan kaidenin müeyyedesi nedir? Müeyyede cem:yetin hukuk kaidesini çiğneyen faile karşl göstereceği tepkidir; bu tepki evelden tayin edilmiştir (Durkheim içtimầ iș bkliumii sah. 24). Bu evvelden tayin edilmiş tepkinin, yani müeyyedenin rahahetini ve șumulünü bahis mevzu hak hakkinddki telakkiler tayin eder.

3. - Hakkin muhtevasi nedir? Bu muhtevayı subjektif hakkın mahiyeti tahdit eder. Çünkü subjektif hak bir vasitadır, hakkin gayesini gerçekleștirecek bir alettir. Binaenalyh hakkin muhtevası Stammler'e göre gerçekleștirecek gaye ile takdir olunmalıdrr; muteva gayenin icabettirdiği zaruretlerden daha ileri gitmez (1). Bu itibarla hakkın gayesi muhtevasının da ölçüsü oluyor.

Gerçe Karl Huber de hukuku insan faaiiyetini caiz olan ve olmayana ayıran sinir olmak üzere tarifeder. Yalnı bir hakikin mutevasi ile ku!lanılması arasındaki nisbeti (orantiyi) tayin etmek lazımgelir. Subjektif haklar, kullanılmaları için kabul edilmișdir. Kullanılmayan bir hak tesirini gaip eder; hatta bazı halde yok olur, med. Kanunumuzun 709 uncu maddesi bu hakikati ifad’e eder. M.K.Mad. 887 fik.2, 889 kullanı!mayan haklarin silindiklerini ispat eyler. Binaenaleyh subjektif bir hakkin muhtevasn onun kullanılmasına sınırlık ettiği hakkile iddia edilebilir. Amma bunun aksi de, yani hakkın kullanılmasinın, muhtevassının ölçüsünü verdiği de iddia olunabilir mi? Hülasa hakkın muhtevasi ile kullamiması birbirile tamamile karıștırilabilir mi?

11) \&Zaruretler kendi miktarlarinca takdir olunur.s Mecelle Mad. 22. zarureti burada yolnız teknik mancida olarak mucbir sebep manasina almağa sebep yoktur: 
Subjektif hakkın muhtevası objektiftir; bunun hududun' objektif hukuk, hukukun genel amacina göre tayin eder. Halbuki subjektif hukukun kullanmasına yeni ve başka bir unsur katılır. Surf subjektif olan bu unsur hak sahibinin iradesidir. Subjektif hakkın kullanimasına mahiyetini veren hak sahibinin iradesini belirten fiildir. Hakkin kullanılmasını bir hukukî faaliyete çeviren yani insan faaliyetini maddi alemde değişiklik yaptırmağa vardıran şey hak sahibinin iradesidir. Buda bizi subjektif haklar'n kullanması ile zekâ ve iradeye malik her insanın nasibi olan genel hürxiyetin kulanılmasi arasindaki orantiyi (nisbeti) farik kllmağa sevkeder. Hayatin hemen hemen bütün faaliyeti hürriyet namina yapllır. Hürriyetin ifası insan iradesinin faal olabildiği bütün sahalara: dınî, siyasî ve hukukî sahalara ફ̧amildir. Tabii, burada bizi yalnız hukukî saha ilgilendirir. Genel hürriyet insana yetkilerini kullanmak enliyetini mutlak bir tarzda verir. Hürriyetin kullanılmasında zahiren gözüken bu hududsuzluk onu hakların kullanmasından ayrrir; çünkü hakların kullanilmasi sinu-lidir.

Fakat mesele daha yakından ve daha esash olarak tetkik edilirse haklarin kullaniriasi ile genel hürílyetin kullanjlması arasında esasli bir fark olmadığı gözükür. Genel hürriyetin kullannilnası de sinirsiz değildir; başkasının hürriyeti ve genel menfaat ile sınırlandırılmıştır. Yani gene! hürriyetin kullanılmasmda hukukun takip eylediği umumî gayeye, imdi unumî intizama uyyun olmalıdu. Gerçe Karl Huber hak. kın kullanılması ile hürriyetin kullanılması arasmda hiç bir müşterek nokta bulmuyor. Ferroshet ise hak ile hivriyet arasinda birincisinin kanunda daha açık sinmlandirılmıs olmasından sarf nazarı edild’ği takdirde bir fark bulunamıacağın ileri sürüyor. «Alfred Martin» de Zeitschrift für Schweizeriches Recht (İsviçre hukukuna ait risalei nevkute- adi meemuada (sene 190) fransızca dilile çıkmis olan «hakkın sui istimali ve haksız fiil» adlı tetkikinde positif bir hakkin kullanılmasile tabii hürriyetin kullanılması arasında fark kabul edenlerin içtihatlarını red eyliyor (sah.31): «Bazı müellifler positif haklarla tabii hüriyetin kullanimaları arasinda bir fark kuruyor. Positif bir hukuku kullanan kimse, kimseye zarar vermez diyorlar; binaenaleyh hakkını kullanmasından dolayı mesul kılınmamalıdır. Halbuki tabii hukukunu kullanan kimse başkasına verdiği zararı tazmin etmelidir.

Bu fark bize göre varid değildir. Cünkü tabii hürriyet namına hareket eden hakkmı kulanır. Subjektif hakların heyeti mecmuası ehliyete. hulkukî muhite, insanın tabii hürriyetine vücud verir. Insan, hürriyetini 
ancak haklarni kulanmak suretile kullanır ve hakkın kullanilmasi da daima hakkầ uygundur. «Haklan kullanan kimseye zarar vermiş olmaz» kaideșinin, aynı zamanda mantıkın ve sağ duygunun kuvveti olan kuvvetinden henüz bir şey gayip etmemiş olduğunu düşünüyoruz.»

Perrochet'ye göre tsviçre hukuku hakkun sui istimali bahsinde $\mathrm{Al}$ man Med.kanunun 226 inci madesinden ve fransiz nazariyelerinden ayrilmaktadir. Perrachet'ye göre hakkın sui istimali nazariyesi, bazılarınun iddia eyledikleri gibi hukuku ahlaklaștırmak gayesini gütmez. Hak kin sui istimalinde alman nazariyesinden aymlabilmek için Alman nazaryesine temel olan Alman med. K.nun 226 inci madesinden aymlmak lazımgelir. Al. m.k. 226 incı maddesine benzer tahdit edici bir metin Isviçre m. k.nunda mevcut değildir. Bazı isviçre müellifleri hakkın kul. lanılmasında zarar vermek kastından başka meşru saikin de bulunmamasın ileri sürmüşlerdir. Perrochet meseleye subjektif mahiyette psikolojik mefhumların katılmasını hukuk kabul edemez diyor. Bazıları zarar vermek kasti ile meşru saik yerine menfaat fikrini kabul ediyor ve böy" lece ahlâk sahasından çıkıp ukuk sahasına giriyorlar. Isviçre kanunu «menfaat», lafzile hakkın sui istimaline benzer başka vaziyetleri farih kllmaktadr. M. k. mad. 24 ve B.K. Mad: 49 șahsi menfaatlara tecavïzden bahseder Isviçre federal mahkemesi vaktile hakkın sui istimaline farika olarak içtimaî ve ahlakî bir farika olan zarar kastını almıștı. Sim. di bu farikay terk eyledi, ve hukukí bir farika olan menfaat farikasını almağa başladı. Demek ki hakkın sui istimalini objektif tarzda takdir edilecek bir menfaatm bulunmaması farik kılıyor. Fransa-da Mosc federal mahkemesinin son içtihatlarına yakın bir noktai nazarm müdafaa etti ve nazariyesine «bahis mevzuu menfaatların muvazenesi» adını verdi. Menfaatlar nasafet kaidelerine göre takdir olunur. İsviçre $\mathrm{m}$. K. nu serh edenlerden Gmür, Tuor ve Oser de menfaat bulunmaksızin kullanılan haklardan bahsetmek suretile menfaat farikásını kabul etmiş olduklannı gösterirler.

XIX uncu asrin başinda bütün kanunlar ferdiyetci tabii hukuk nazariyesini kabul etmişlerdi. Bu telakkiye göre haklar sahiblerine aid olur ve rakip haktan başka da bir sinır kabul etmez. Bu telakki insanlarlar için yalnız onlamn şahsi menfaatlarma hizmet eden mutlak haklar kabul eder. Fakat XIX üneü ası'n içinde ferdiyetçiliğe kar\$̧ı bir tepki husule geldi; fert içtimaî viicudun içinde bir hücre gibi telakki edilmeğe başlandı ve ferdin içtimaî vücude lazım olduğu nisbette gelişme sine muisaade olundu. Bu fikir thering tarafından da ifade edilnişti. 
Perrochet hakkın sui istimaline farika olarak hukuk ile hakiki hukuk arasindaki ihtilafi aliyor. Hakiki hukuk muvazene halinden baska bir şey değildir diyor. Isviçre m. K.nun başına geçirilmiğ prensiklen hakiki hukukun temayüllerini gösterír. Hususile 1. inci maddenin 3 üncü fıkrası yargıçı, hakiki hukuktan geniș mikyasta ilham alimas na imkân veriyor; çünkü formülleştirilmiş hakların kullanlması ile hakiki hukuls arasndaki ihtilaf kanunun eksik bulunduğu yerlerde: Iktisadị gelișmenin yeni hal tarzları icabettirdiği yerlerde meydana gelir. Kanunun eksikliklerini yargıç hakiki hukuk ile tamamlayacaktır. Kanun koyucusu medenî K.nun ilk madcielerinde, kanunun hakiki tatbikat kannunut tej̧ $k$ :l eden ve hakların hakiki hukuka göre kullanılmasını emreden prensicler koymuştur. «Perrochet diyor ki: «Kanun koyucusu, bu prensibleri kanuna ko. yarken ahlaka bir yer ayırmağı düşünmemiștir. Hatta kanum ahlaktan bahsettiği zaman dahi ahlak kaideleri kiymuş olmayor; hukuîî kaideler koymuș bulunuyor. Adet ve adalet tabirleri içtimaî ve ahlakî bir hal ve vaziyetin ifadesidir; bu kavramlar hen haklı ve haksız telâkkisine göre hukukî olarak, hem de iyi ve kö:ü telakkisine göre ahlaki olarak takdir edilebilir.»

Hakkın sui istimali hakkmda, arkası bir tïrlü kesilmeyen tartısmalara burada son verip tabii hukuka geçelim.

19. - Tabii hukuk tabiri çok eski bir tabirdir. Gerek eski Yunan. lılar, gerek romalı!ar, gerek Ciceon hulasa eski çağin bütün filosofları hukukun tanzim edeceği münasebetlerịn kaynağın tabiața, tabiat hukukuna yaklaștirmak hususunda büyük bir meyil gösterdiler. Birim eski tabirlerimiz arasinda tabiat hukukuna rastianılmaz. Ciçeron'un ve eskilerin taibiat hukuku tabirile ifade eyledikleri kavramı islam hukukcular mutlak acalet (adlı mutlak) tabirile ifacle ederlerdi. Böylece islam hukukcuları ada!eti ikiye ayırmışlar: değiştirilmesi aümkün olan hukuk kaidelerine nisbî adalet adını vermişler ve zamanda değișmesine imkân olmayana mutlak adalet demişlerdir.

Fakat bugün tabii hukuk tabiri XVII inci asırda vücude gelmis buIunan ve Grotius diye meșhur olan Holandal nukukçu ve diplomat Hiu ges van Groot'un kurmuş olduğu felsefî bir doktrini ifade eder. Bu doktrin (ilmî içtihat) Grotius'un XVIJI inci asırdaki talebleri tarafından şevk ve heyecan ile ele ahndı ve Fransız büyük ihtilalinin iham kaynağını teșkil etti.

Tarihî mektep çıkınca tabiat hukuku mektebi hücumlara uğradı ve terk olundu. Bugîn tabiat hukuku tekrar çeşitli şekillerde doğmağa başladi. 
Täbiat hukukinün atası olan Grotius tabii hukuku en yüksek mevkie çlkartabilmek ve ona başka mefhumlarla karıştırtmamak için $\mathrm{Na}$ safet karraminın küçültmüș ve onu sırf teknik bir manaya indirmiștir.

Grotius nasafet beyanındadir (De Aequitate) adını taşıyan eserinde nasafeti tabii hukuk ile karıștıranlarm hata etmekte olduklarmı söyledikten sonra nasafeti söyle tarif ediyor:

«Has ve kendisine özel manasile nasafet. iradenin, Kanunun genei mahiyeti itikarile yaptığı halaları düzelten bir hassasıdır. Nasafet kanunun düze!tilmesidir.» Yine Grotius aynı eserinin bir başka yerindc «kanunu düzelten doğru endişedir» diyor.

«Grotius'a tabiî hukukun atası denmiș olmasının sebebi tabiî hu kukun üç karakterini Gratius'un tayin etmiș olmasıdır. Bu üç karakiere hukkun bütün felsefi veya metafizik telakkilerinde daima rastlanmaktadır. Hukuktun ahlakî telakkisine mensup bulunduğunu id j̦ia eden her nazariyeye, o nazariyenin sekli ne olursa olsun hukukun felsefî veya metafizik te!akkisi adı verilir. Şimdi bu üç karakteri arzejelim:

1. - Tabî̀ hukukun ispatı ve ikrarı.

Bir tabiî hukukun varlığ: iddia ve ikrar olunmaktadr. Grotius bu iddia ve ispatı, gurkette yazmıș olduğu savaș ve barıș hukuku (De jure belli ac paci) adlı büyük eserinde yapmıștır.» Tanrı tarafından dahi değiștirilmesi mümkün olamıyacak kadar mustakar (yerleşmiş) bir tabii hukuk vardr. Tabii hukuk, insan mahiyetinin insanın kendisinden ayrılmaz bir parçası kıldığı aklın verisidir (1).

Grotius tabiî hukukun meșrutiyetini, filosoflarin, ahlakclarin, tarihrilerin hatta şairlerin genel ve evrensel ittifaklarma dayandwiyor ve bir takım nakiller yaptıktan sonra bu mïsahedelerinden şu netice kartıyor: «Eğer gerçekten tabii hukuk olmasa idi bu kadar tartışma olmazdl.»

II. - Doktirnin ikinoi karakteri tabî̀ hukukun tahliłinden çıkar ve tabii hukukun muhtevasını tayin eyler. Bu tahlil insanlar aras'ndaki eşitliği meydana çıkarır. Tabii hukukun muhtevası, insanlar arasinda insanlrk şerefinin icapettirdiği bir eşitliktir. Tabiî hukuk doktrininin bu

(1) eNizam-u intizam-u alem muhteremdir nez-i baride Hüda kadirdir amma simi zer, levli nihar eylemez.s

«Doğru aklın tèlkin eylediği laniatłı̆ı) kaide bir filli shkasiz veya ahlakî dive va. siflandirmağa imkân vèren ve tabiatin varatıcısı olan Allah da haksızı yasak etmekte ve chlaklıyi emir buyurmaktadirs losstius Liv. I chap. Is 10). Fakat Allahin bu emrini akil kesteder; Leibniz"in fabirile sruhlarımıda ilahî bir tarzda vakılmis olan ebedi akil bu. dur ve mevdano cokarit. 
eihetini Holandalı üstadin talebelerinden Pufendorf daha ziyade bariz kulmış ve doktrinin her tarafta kabul edilmesine yardım eylemiştir: «Tabiat kimseyi hemcinsleri łzerinde, hemcinslerinin mütekablen kendisine karşı kullanmıacağı bir hak ile müntaz (imtiyazlı) kolmanuştir».

III. - Doktrinin üçüncü karakteri tabii hukukun neticeleridir (hükmüdür). Tabî̀ hukukun amacı, elde etmek istediği netice şudur: «Tabiî hukdk âlidir (yücedir). Tabî̀ hukukun bu yüksekliơgi onu her kese karşı galip ve üstün kllar; hatta hükümdarlara üstün ve onlara emir edici kular» (1) Bir hükümdarnn otoritesi tabalarm bir nevi vekâletinden doğar. Grotius'un taclı baslamn egemenliklerine dair yaptığı bu sıkı tahlil «insan ve vatandaş hakları beyannamesininde «zulme, tazydka kar\$1 koymak» adını aldı. Grotius'un vicdan hürriyeti kavramın tahlil etmek. te özel bir sebeb ve menfaati vardı: müebbed hapse mahkûm olmuş ve zindana atılmıştı. Grotis hapisten kaçmak ve sürgün demek olan gurbet hayatına atılmak suretile kurtulmuştu (2).

Tabiî hukuk doktrinin üç verisi (mutası) üç karakteri bundan ibarettir. Grotius'un haleflerinde, XVIII inci asrın filosoflarında tabiî hukuk doktrininin yeniden doğduğu zamanımızda daima hukuk fikrinin iddia-

(1) «lslam âlidir ve ondan daho âii hiç bir soy voktur düsturu ki \&Adalet alidir ve ondan dcha âli hic bir sey yokiurs veva stiak âlidir ve ondan âli hic bir sey vokturs seklinde de ifade edilir. Grotius'un «tabii hukuk âlidir ve ondan doha âli bir sev voktur» düsturunun mahivet itibarile ayndır. Hükümdarların hudutsuz kudretlerini dini bir mefhum olan Allah ile veva lâvik bir kavram olan rabii hukuk ile sinırlandırmağı amac edinir. Osmanlı padisahları Allaha kerși isledikleri suçlarından ötürü tahtlarndan indirildiler. Bugün Hürrivete karsi işlenen suçlar tahtlan ve reïimlen vikıor. Hürrivet ve halk hakimi. veti cumhurivetin muhtevasıdir. Din \&Allah» kelimesini vükseltmek ister, Osmanlı seferle. rinin ülküsü bu idi. Cumhurivetin gerçekleștirilmesini ister; Kemalizmin ülkŭsü budur. Bu izahlardan cinlarilacağı iktidarın zulmune karș kovmak caresini akl!n tabiattan bulup ckkartŭg tabii hukukta ifadesini butmustur.

(2) Bugün egemenlik, Fransız daha doğrusu Esmein'ın nazarivesine göre milletin hu kukî ifadesini ve tüzelkișiliğini teşkil eden Devlettedir.

Tüzelkişi olan Devlet egemenliği haizdir. Devlet halkı zor ile itaate mecbur kılmak vetkisini haizdir. Fakat devlet avni zamanda hak süiesidir vani hukuk ile bağlıdir. Bazı kanunlari yapmağa ve bazılarıni vapmamağa mecburdur. Devletin borçarını vapmaması vova fena vapması onu mes'ul kılar (hizmet hatasi) Devlet mülkivet hakkına, hürrivete dokunduğu zaman mes.ul olur.

Devlet Anayasasinın temanatina rağmen, kanuna göre vapmaması lázımgelen sevi vaparsa veva vapmes; lozımgelen seyi vapmazsa zulum tazyik loppression, vani kudreti suilstimal volu lle ezme; misal halk eziliyor) vücuda gelmis olur. Bütün dünya cnavasaları Devleti hakka riavet ettirmek için teminatiarı ihtiva eder; buna raŏmen bürün dün. va devleteri hakk ihlal eylenokte israr eyler. Meclis, yara veya idarenin de yapmalar lazzmoalen seyi vapmamalar vahut yapmamalar luzmgelen sevi yapmalar zuluri 
sina; onun eşitlik kavramina varan analizine (tahliline); amme kudreti karşısındaki içtimấ rolüne; bu üç larikanın tebarïz ettirilmesine rastllyiruz.

Filosofların, ahlakciların, hukukcuların kalemlerine bu üç farika Montesquieu'nun nazariyesinin esasını teşkil etmiştir. Montesquieu'nun meşhur formüllerini tabii hukuk nazariyesi vermiștir. «Kanun, umumiyetle insan aklıdur; dünyanm bütün halkin idare etmesi yönünden insan aklidur.» (Kanunların ruhu kitap I fasll III positif kanunlar). Montesquieu'nun bu formülü fransız k.m. layihasına alınmıştı: «Bütün positif kanunların kaynağı olan evrensel ve değişmez bir hukuk vardır; bu hukuk insanlar idare etmesi bakmmindan insan aklından başka bir şey değildir.» Layihaya girmiș olan bu formiul kanuna alınmadı.

Montesquieu'nin eserinde insanlar arasındaki eşitlik lehine heyecanIn bir savaşa da rastlanur. Montesquieu mezkûr eserinin kulluğa tahsis eylediği XV inci kitabının II inci faslında kulluğu tenkid eder. Montesquieu hukuk fikrinin, amme kudretine karș oynadiğı rolii șiddetli bir dile ile ifade eder. Montesquieu bu husustaki fikirlerini eserinin bilhassa. vicdan hürriyetine tahsis eylediği $\mathrm{XXV}$ inci kitabınin 9 üncü faslında

olur. Anayasaya aykırı bir kanun da ezici olabilir. Kuran islâm aleminin anayasası bu. lunmus olduğu müddetçe ona avkırı olarak vapılmıs sevlere zulum denirdi

İctimaî bünye ile her vatandasıin zulma karșı koyması hakkıdır. Bu hak sinsan ve vatandas hakları beyannamesis nde tabii ve müruru zamana uğramaz yani düssmez bir hak olarak ilan edilmistir (mad.2).

Ferd zulma nasıl karsı kovacaktır. İslam hukukuna göre bu karsı koymava müteaddi (tecavüz suretilel olur veva pasif oilur. Sultan Selim düsmanla ticaret yapan altmıs ta. cirin öldürülmesini emrettiği zaman meshur zenbilli Ali ef. «Muhakkakki o (Allah) zalimleri sevmezs ayetini okuyarak tłına binmek üzere olan Sultan Selimin önüne dikilmis ve emri geri aldırmışır. Müteaddi tarzda karș koymak maddi kuvvef kullanmak yani avaklanmak suretile veva buna güc yetmez ise söz ile karsı kovmaktır. Zenbilli de sōoz ile karsı koymustu. Pasif karși koymak islam hukukunda zalima karsı kalb de kinbesle. mekttir; ayrupada messu olmayan emrin yapilmaması suretile vaki olur. Avrupada Senloma (Saint Thomas) ayaklanmayı mesru müdafaa olorak kabul eder. Yalnız islamlar gibi dūşunuür ve hududunu aşmamasını isier; vani izalesi lâzım olan zararın kendinden büvük bir zarar ile izale edilemiveceğini ve ayaklanmanın izale edilmesi istenen zu. lumdan daha büvük kötülük vapmamasını ister. Islâm da zararın, hatta kendisine esit bir zararla izalsi kabul edilmez. Locke de ayaklanmavi kabul eder, valnız cosuriluğun mutlâkivetini kabul eden Janiak Ruso (Roussecul ayaklanmağ kabul etmez.

Kanuna aykırı olarak hareket eden bir memura karsı konabilir mi? Ceza kanunumuzun 254. 265 maddeleri bur.a müsaade etmez; valnız karsı kovan hakkında cezayı háfifletici sebep olarak kabul eder iceza K. Mad. 258 fik. IV. Gerçe mezkûr maddenin mezkûr fikrasında sicabına göre ceza büsbütün de kaldirılabilis abii bir cümle var isede takdiridir. 
zikreyler. Montesquieu hukuk fikrinin, amme kudretine karşı oynadığı rolü siddetli bir dile ile ifade eder. Montesquieu bu husustaki fikirlerini eserinin bilhassa vicdan hürriyetine tahsis eyleủiğ $\mathrm{XXV}$ inci kitabınm 9 uncu fasinda zikreyler. Montesquoeu'nun eseri tabii haklarin temina. tı olan siyasî hürriyetin nazariyesidir. Montesquieu'nun cseri Grotius'un doktrininin ifadesidir.

Bu husustaki geleneği temsi! eden scn filosof Koenigsberg filosofu diye meşhur olan Kant'ur. Kant'in da koyduğu ve ilân eylediği üç prensip, her ne kadlar içtimaî felsefesi telakkisine, onun ahlakî kaidelerden çıkarttığı hukuk telakkisine özel bulunuyorsa do Grotius'un koymus olduğu doktrinin neticesi olarak ta görmemeğe imkân yoktur. Ahlakını klasik bir veri haline getiren kant «kudretin, erkin evrenselliği» noktasindan hareket eyliyordu: $\ll \mathrm{O}$ sureite hareket et $\mathrm{ki}$ faaliyetinin-düstüru senin iradenle evrensel bir kanun haline gelehilsin:» Iste Grotius'un birinci verisine doktrininin birinci farikasına, birinci netices ne eșit bir prensib. Kant'ın evrensel erk nazary esi həkkın iddiası, ikrarı ve ispa tıdır. Kant'a göre hak aklın ve fikrin bir mahsulüdür, insanın iradesile kanun haline getirilmiș fikirdir; hak bir iradedir.

Kant'ın ikinci prensibi insanlığin kendi kenüsinin gayesi bulundn ğu prensibidir ki Grotius'un ikinci verisi gioi muhtevaya taailuk eder. O muhtevan!n analizi (tahlili) insanların birbirlerine karșllık ve esit sayg göstermesi şeklinde tebaruz eyler. Kant'a göre insan, ve umumiyetle her akıl ve fikre malik mahluk kendi ken.isinin gayes dir (hïrlük te budur yoksa şu veya bu iradenin keyfi olarak kullanilan aleti ve vasıtası değildir. (Kul ve eşya kenải kendilerinin gayeleri değildir sahiblerinin gayelerinin a!etidir). Insanlarin birbirlerine korollkh ve esit saygi göstermeleri luzumu Kant'in hukuk metafizikinde sbirlikte var ofmak» düsturu adını tașır. Hukukun gayesi, her kesin hürriyetinin, diğerlerinin hürriyeti ile bixlikte var olabilmesi șartlarini tayin etmekten ibaretti. Kant hukukun, meşhur olan tarifini «birlikte var olmak» formülünden çıartmiștır; «Herkesin faaliyet yetkisinin, evrensel hürriyet kanunu gereğince bașkalarınin faaliyet yetkisile uyușabilmesi șartlarıdur.»

Kant'in Grotius'un üçüncü prensibine eșit olan prensivi de shak âlidir ve ondan daha âli hiç bir şey yokiur» prensibidir. Hakkın bütün âmme kudretlerinin üstünde duran ve on!arı yükleyen bir yüceliği var. dır. Çünkü insanlık kendisinin gayesijir; bu itibarla ceni et müşte:ek 
kanunlarla birleștirilmiş akıl ve fikre malik insanlarin birbirine sistemli bağlanmalarından (irtibatından) bașka bir șey değildir. Insan!rn birleştiren müșterek kanunun ne oldugunu tayine gelince, o büitïn insanların birbirile ve birbirlerine nazaran kendi kendilerinin ga: esi olarak muamele yapmalarindan ibarettir. Kant remiyeti, «gayeler saltanatı» «illet-i gayı saltand ve iulkesi» olarak tarif eder.

Evrensel ve değișmez bir hukuk fikir ve telâkkisi cok tenkide uğradı ve hatta çok slaya alındı. Insanlar kanunları Tanrının bağışlaması olarak kabul ederek isse koyulmuşiardır: Tevrat ve Kuran bu telakkinin eserleridir. Kanunlamn Tanrı ya koydurmayan milletler onu bir dahinir. dimagından frşkırtmışlardır: Giritlilere kanunlarini «Minos» vermiștir; Ispartalılara Likurk (Lycurgue); Atinalilara Solon; Romalilara Romulus ve Numa vermişlerdir. İptidaî cemiye!lerin farikası olan bu zihniyet XVIIT inci asrın sonlarına kadar: tarihi mektebin kurulusuna kadar pek büyük adamların da kanaatlerine temel olmuștur. Çok meshur Ingiliz filozcfu «Locke» Karolinin Likürkü olmak hevesine kapılmıștı. Jan Jak Ruso Korsika ve Polonya için yeni baștan bir nizam kurrnağı hayal et: mişti. Bentham Ispanya için yeni bir siyasi hukuk yaratmağa yeltenmiști. Bu büyük adamlar aldıkları kanun siparișini yerine getimneğe uğ. raşmışlardı. Kanunların gelişme tarzını hatta hukukî telakkilerin gelișme tarzinı meydana koyan tarihi mektep tabii hukuk nazariyesini yıktı. Hukuk ne tanrilarin ne de Dahilerin vergisidir. Hukuk tabii hukuk ta değildir, yanì kendiliğinỏen anlașılan, yalnız doğru düşünmekle bulunan ve meydana çlkartılan tabiat tarafindan veri!niş, arem oğullar.na müsterek ve evrensel, hiç değişmez ebedî hë̈ zamanın ve her milletin ihtiyacına uyar bir hukuk ta değildir ve böyle bir hukuk ta yoktur.

Tarihi mektep hukukun, XVIII inci asran sanmı olduğu gibi fikrin sun î bir mahsulü olmayıp tarihin vücude- getirdiği bir șey olduğtinu is pat eylemiştir. Hukuk millet hayatınin muayyen tekamül merhalelerini ifade eylemek zorundadır. Tarihin çocuğ olan hukukta, değişmeyen ve daima olduğu gibi kalan mutlak bir iddianın izlerini aramak hata olur. Tarihi mektebe göre hukuk milletin şuursuz kanatlarındin ve hayatindan fışkırır; hukuk sadece örf hukukudur. Kanun ve örf hukuku tabirleri birbirlerine eşittir. Örf hukuku kanun hukukunu yalnız tamamlamaz aynı zamanda değiștirir ve hatta ilga eder.

XVIII inci asrin, hukuk ilmini telakki tarzına göre hukuk kanundan ibarettir, kanun hukukudur; örf hukuku ise karun koyucüsünün zimmen 
kabul eylemiș ve böylece kanun kilmıs olduğu hukuktur. Savingy ile baslayan tarihi mektep telakkisine göre ise hukuk örf hukukundan ibarettir. Hukukun muhteviyatın kanun koyucusu keyfì bir tarzda tayin edemez.

XVIII inci asır ile XIX ncu asur birbirinden ayran telakki, hukukun menşei hakkındaki telakkidir. XVIII inci asır düşüncesine göre bir çocuk ancak bir kadından doğduğu gibi hukuk da ancak kanundan doğar; hukukun örften oğması tamamile istisnaidir. Devleti kanun ile donatan kanun koyucusudur. Hukuk esas itibarile yaymlanmıs kanunların toplamıdır; hukuk yasama erkinin bağışlamasıdır, onun keyfi veya şuurlu kudretinin mahsulüdür. Hukuk halka yabancıdır; hukuk halka tatbik edilir ve halka tahmil edilir. Halk hukuku ögrenmeğe ve benimsemeğe mecburdur.

XIX uncu asrın hukuk anlayıșına göre ise hukuk, doğrudan doğruya halk zihniyetinin mahsulüdür. Millî hukuk hissinin derhal bir fiil ile gerçekleşmesi ve adet șeklinde ifade olunmasıdır. Zaman ile kanun ikin. ci bir kaynak olmak üzere örf kaynağına gelip katılır. Kanun daima yeni bir șey yaratmaz; ekseriya var olanı bildirir.

Tarihi mektep te mübalağa ve ifrada saptı; tedvin hareketinin siddetle aleyhinde bulundu. Hukukun örfi halden kanuni hale geçmesinin hukuk için ifade ve temin eylediği o büyük terakki ve tekamülii anlamak istemedi. Diğer taraftan her zamanda yıldızlar gibi ferağ edilemeyen ve parçalanamyyan ebeāî yir hukuk düşüncesinin hukukun gelișmesinde oy nadığı büyüik rol inkâr kabuletmez bir hakikattir.

Bu itibarla XX inci asır da tarihí mektebe karşı bir tepki asri olmuștur. XIX uncu asrın sonlarında ve XX inci asron baslarinda tabî mek. tebin yenicen doğumura şahit olunmuștur.

Saleilles'in «baz yeni eserlere nazaran tarihi mektep ile tabii hukuk» adlı mukalesinden yukarıda bahseylemistim. Tabii hukukun durgunluğunun uğradığı itirazları kaldırmak ve yıkmak için Stammler'in «mhteviyatı durgun olmayan» tabii hukuk telakkisine iştirak eylemiş olduğunu da bildirmiştim.

Geny'nin özel hukukta ilim ve teknik adlı eserinde «Daha basita irca edilmeyen tabii hukuk» anlayışından da bahsetmiştim.

Prof. Georges Renard'da «Hukuk, nizam ve'akıl» adlı eserinde tabii hukukun taraftarı olduğunu bildiyor. Renard ve diğer tabii hukuk taraf- 
tanı dindar profesörler nazariyelerini dini bir inaniga dayandırıyorlat (1) Renard «ilâhî aklın bir yansımasi olan insan aklının bildirdiği ve insanin özel mahiyetinde kökleştiği ebedî ve müstakar bir hak vardır.» diyor. Renard'a göre bütün haklarımızdan evvel var olmuş ve nizam şeklinde vücude gelmiş bir hak vardur. Bu nizamda herkesin yeri ayrlmıştır herkes kendisine ayrılan yerde meşruiyetinin hiliccetini (senetini), gayesini, ölçüsünü ve hududunu bulur.

21. - Şimdi Ripert'in «medenî borçlarda ahlak kaidesi» adlı eserinden bahsetmek lazımdır.

Ripert tabii hukuk fikrinin ve nazariyesinin muhalifi ve hatta düș: manıdir. Ripert tabii hukuka karşı: onun verilerin ve muhtevasına karşı yaptığı tenkitleri, Gency'nin eserinin tahlili vesilesile yazdığı «tabii hukuk ve hukukî positivizma» adlı' yazısında yapmıştır. Gency bu tenkitlere eserinin son cildinde cevap vermiştir.

Ripert «tabii hukukun muhtevasnı aramak kadar kisır bir çalıșma olamaz» diyor. Tabii hukuk nazariyesini kabul eden müelliflerin bu na.

(1) Hiristivanlıăın hukuk üzerindeki tesirị tartısmalidır. Hiristiyanlık bir voktan doğmad bosluktan sıkmadı. Kendisinden evvel var olmus doktrinleri topladı ve bir hamur vaptı. Bütün tapınaklar escki tapinakların sütunlarile inşa edilir. Hiristyianlik üzerinde en cok tesirini yapmıs olan doktrinler, islamivet üzerinde en cok tesirini göstermis olan istoa mektebi felsefi ile Hind ve israil oğlu felsefesidir.

Istoa mekłébi iki büyük ahlakı hareket tarzını prensib olarak koymustu: 11 Herkes hürdür ve bu hürriveti dolayısiyle ahlâkî iviliği gerceklestirmeğe mecburdur. Bu ahlâkî. ödev hiristivan dilinde de, kuran da sadil vè ihsań (sefkat) adlarını tasıst. Her Cuma oünü hatip hütbeve baslarken sallah adaletle ve sefkatle hareket etmenizi emrevler» ayetini okumakla baslar. 2) Herkes hürdür ve bu hürriyet ma'sumdur (masundur, doku. nulamazl; bu da istoa mektebinin hak prensibidir.

Hiristivanlik istoa mektebinin birinci prensibini aldi ve kend ahlak telakkisini bu prénsibe davanırdı; fakat ikinci prensibi almadı ve ahlakını hakka davandırmadı; çünkü sarkın faal olmaktan ziyade kendinden geçmeği emreden, vani veçi, Allahın gü.: zelliăini kendinden geçerek can gözü ile seyr etmeăi ve düsünmeği emreden felsefesi hiristiyanlığa da tesir evlemişti. Islam derviși cırpinmaz: «Ceyb-i tefekküre dalar; cevb. hem elbise yakası demektir, derviş onu başına ceker, hem vürek demektir, dervis yüreăi il allahını düsünür. \&Allah nedire devince gâfil. Allah! devup kamus olur dil» sark fel. sefesi sabri, tahammülü ve tevazuu emreder; dervis nihat olanlar Inihat bir. sevin asli, yapilısı demektirl her seve eyvallah derler. «Ne kılsalar ana sad; ne verseler ana sakir».

Brahma dini en büyük saadeti insanın allahla karısmasında bulur; buna islam di. linde fena billah nasıl denizde benliăini gayri petür denize karısıvor ve onunla bir oluvorsa insan da altaha akmalı ve o büyük varlığın içinde erivip gitmelidir. Bu sebepten Brahma dini feragati vani her seyden el etek çekmeăi, her sevden vaz gecrnecil, sabri ve valnizlık ve sessizlik içinde vecdi tavsive evler. Bu zahiri varioğin Nirvana ile vok edilmesini emreder. Nirvanava mutlak bir feragatla ve içdeki bütūn arzuları sündürebı. mekle varılabilir. Hırístivanlığa ve islamlığa geçmis olan bütj. bu eski sark folsefeleri

Hukuk Faküiltesi Mecmuası : 22 
zariyenin içine neler sokmuạ oldukların tayin etmeğe imkân olmadığını söyleyor. «Bu kitabdaki önerme!er bir tabii hukukun varlığının iddiası gibi alınabilir. Çünkü medenî borcun tamamile anlaşılabilmesi ve teknikçe inșa edilebilmesi için ahlakın insanlar arasında kurduğu müna: sebetlerin hukuki bir ifadesi olduğunun daima akılda ve göz önünde bulundurulması lazim gelir. $\mathrm{Bu}$ da borçlar hukukun ahlakì bir ülkü olan adalete, yani esas itibarile eski tabii hukuka dayandır.ak olacağının ileri sürülebilmesine imkân verir isede ben böyle br şey düşünmekten çok uzak bulunmaktayım. Tabii hukukun muhtevasını araștırmaktan daha kısır kalmağa mahkum bir araştırma bilmiyorum. Geny çevreyi dahi ilerletmenin çok çekici ve fakat çok güç bir çalışma olacağını itiraf ediyor ve şahsan bir çalışmaya teșebbüs etmiyeceğini bildiyor... Adalet fikrin. den hareket etmek suretile bütün bir borç nazariyesi nasıl çlkartılabilir? Nasıl dünya ve insan hakkında sırf şahș' ve indî bir telâkkiye düșmeden çıkartılabilir? Tahlil ile çıan neticeye göre «yapım» fikirden daha ya. vaş değișir. «Veri» «yapım» in içine yerleșir. Bizim de borçlar ñzari-

şafkatin kutluluğunu ilân ediyor fakat hakka yer vermiyar. Artik (eski) Hiliel acili mieshur vahudi esana yapıld:ğın istemediğin sevi sen de baskas!na vapmas düstur'siuj Isadän b irasır evvel bevan etmisti. Bu düstur atalarımız silinde sevvela ğnevi kendine supla sonra cuvaldızı aleme seklinde tatbiki bir tarzda ifade olunmustu.

Hiristivanlığı hukuk sahasında istog mektebinden aşağı kılan sey hakkı beyan etmemis vani hürrvietin masun olduğunu ilan etmemis olmas dir. Bu aşağ vazivet müevye. de sahasındaki bcsluklarla daha fazla açilivor. Tam saadeti Allaha malik olmak vūcude zetirdiăinder bu saadete ancak ölümle erilir.

\&Bmar-i hicra nile bizariz. Elminnetü billah müteheyvi-i mematız «biz ayrilık has ralığı ile hastavız. Allaha minnet olsun ki, cok sükür ki ölüm için iktiza eden surete girip ona hazirlandik» (Sair Hersekli Arif Hikmet beyin müptela olduğu k:rtlak kanserinden ölmeden pek az zaman evve! sōylemis olduð̆u bir kıtadır). Mesnevî bu ayrılıkın sikâye. lini anlatmakla söze baslar. Bu düsürïs dünyadaki hayattan ve servetlerden, rahat ve ivilikjerden el, etek sekmeği icapettirir ve hayatı hor gösterir. Kuranda bile havat için abir aldanma (gurur) meta'ından baska bir sey değildir» denmistir. Meshur kuran tef. sircisi Zimahseri bri arab kabilesinin paçavrava egurur metai» demekte olmalarını nak. !ederek avete havat bir pacavradan baska bir sey değildir manasını verir. Hayat bir paçavradan başka bir sev olmavınca siyasi, içtimaî ve hukukî teskilàtın hiç bir kiymeti olmaz. Hakiki vatan öbür dünvadır. Odevlerin bu alemde müevvedeleri voktur. Zalim. ler öbür dünvada cezasını çekeceklerdir.

Bu sebeplerden dolavı Hiristivanlık hukuka kâfi temel teskil etmez. islâmlığın hiris. riyanlık üzerine üstünlüğü de buradan gelir. Islamda ki tarikat, «tasavvuf» ile seriatçılık arasındaki ihtilaflar insanlar arasındaki en ivi münasebeti bu dünyada vücudè getirmek arzusundan doğmustur. Pasif karsı kovma, ezilenlerin her türtü savunmadon vaz geçip isi Allaha havale etmeleri zulme cok ivi firsatlar verir.s Haddini bilmevene haddini bildir mek. öksüze kaftcn givdirmek gibidir» (ała sözü). 
yemiz Ròma şekillerinin içine yerleşmiştir; halbuki biz Roma telakkilerinden çok uzaklaştık.

Mukavelenin herkese baş kestiren bağlayıcı kudreti olup olmadığını veya yargıçın onu düzeltmek kudreti bulunup bulunmadığını; mürabahacılık zulmünün mukavelenin butlan sebebi olup olmadığını; tazmine hatanın mi yoksa ihdas edilmiş tehlikenin mi esas tutulacağını; başkasına sağlanmaş hakstz mal iktisabının iadeye tabi tưtulup tutulamıyacağinI, muntazam teknik şeklin kasta üstün kılmıp kılınamıyacağını veya sui niyetin muamelenin intizamın bozup bozmıyacağını; mütesep hafkkın cezadan masuniyeti sağlayıp sağlamadığını veya hakkın sui istimalinnin tenkil edilip edilmeyeceğini bize tabii hukuk bildirecektir, diyeceklerdir. Bütün bunlar esas!ı ve ana probemlerdir. Bu problemlerin bazları çok eskidil ve asırlarca tartışma konusudur, bazıları da daha yenidir. Mevcut hukuku müdafaa edenlerle de yarınin hukukunu isteyenler de arzuların adaletin dikte ettirmekte olduğunu iddia ediyorlar.

Hakikatte, siyasî kudrete karşı bir protesto mahiyetini tașımıș olan tabii hukuk nazariyesi kendisini yalnız hukukun teknik olușuna hasretmek arzusunda bulunan hukukcular için elverişli ve rahat bir vaziyet haline düșmỉsştür. (1) Sirf insanî bir hale düșmüş̧ olan tabii hukuk umumî efkâr ile karıșnuș ve ona eşit olmuștur. Bir dereceli ve genel oy ile seçim devrinde umumî efkârı ifade eylediği sanılan yazılı kanunun temel ve mesnedi olmuștur.

Ahlaki fikirlerin bu perişanlı̆̆ devrinde, savașin vücude getirdiği içtimâ̂ karışıklığı arasında bize tabii hukuktan daha saglam bir disiplin ve ondan daha kuvvetli bir faaliyet sebeb ve hikmet lazımdır. Bu agır imthanlardan sonra «aydin bir millet hukukunu yeniden düşünür» (Lewy - Ulmann, hukuk tarifi) Bir milietin istikbali fikirlerinin istikbaline bağlıdır.» (Ripert ahlâk kaidesi No. 207)

Ripert eserinin ön sözünde de tabii hukuk hakkında șunları yazar: *Kimisi hali hazır müesseselerini, sosyoloji kaidelerinin onların değiștir-

(1) Siyasî kudreł daima sui istimal edilmisttir; ve insanlık daima bu suiistimali protesto etmiștir. 1910 fransız demir volları isçilerinin grevi hadisesinde sol taraf başbakanın (Briänd'in) hareket tarzını «siyasî kudretin suiistimcili» olarak tavsif eylemiști. Sağ taraf saylavlarindan hazır cevap olan ve kültürü kuvvetli bulunan «Charles Benoist» oturduğu verden esui istimal edilmevecek bir kudrer neye yarar» sözünü «siham-i kaza» gibi firlatmısti. Bu act hiciv sui istimal efmediăi kudret vükü alında ezlmis «Omer» in ne için ver. lere vatıpta o vükten kuriulmak için canını almasını Allahtan yalvarmıs olduğunu anlat. rŏı gibi suiistimal edilen bir kudrete hurs ile bağlanmanin sıraiarını açıklayor. Insan sirosî kudretin sui istimaline Allah, hürrivet ve tabil hukuk adlarina mütemadven protesto etnistis. 
melerini emretmekte bulunduğu bahanesile yıkmağa uğraşurken kimisi de o müesseselerin tabii hukuka uygun bulunduğunu byan etmek suretile yıkılmak istenen müesseseleri çok gevşek bri tarzda müdafaa etmektedir. XIX. uncu asır boyunca, evrensel bir suç ortaklığile, positif hukuka tabii hukukun hakim bulunduğuna inanır gibi gözülküldü. Tabii hukuk Devlet dini kılınmıstı. Resmî bir din ve doktrin sahibi olmaktan men edilen devlet tabii hukukta resmiliği veremez oldu ve böylece tabii hukuk kuvvetsiz kald. Fakat tabii hukuku himayeden vazgeçmiyenler bulunmakta devam ediyor; ve surf positif hukukun üstünde bir ahlâk kaidesi olduğunu yazmıș bulunmamdan ötürü beni de, protestolarıma rağmen tabii hukukun koruucuları arasına katıyorlar.

Ripert tabii hukuk doktrinine karşı bambaşka bir doktrin koyuyor. Ripert'e göre hukukukn teșekkülü üzerinde müessir olan ahlâki verilere «ahlâk kaidesi adını veriyor. Ahlâk kaidesi, yani ahlâkî mu'talar, Rípert'e göre hıristiyanlığın ilham eylediği ve batı Avrupada evrensel bir muvafakatla kabule ve bu itibarla her tarafta dinin, aklın ve vicdanın teklif eylemesi dolayısile riayete mazhar olmuş ve müşterek kaide haline gelmiș ahlâki fikirler toplamıdır. Ripert'in bu husustaki sözlerini yukarida zikreylemiștim.

Ripert, kitabınin son bahsi olan 208 No. lu parçasinda «kanun koyucusunun veya yargıçın ahlâki kanunu. dikkat nazarına alması istendiği zaman onlara, teyid eylemeleri istenilen kaidelerin ulviyetine (alî olduklarina) kanaat hasil ettirilmelidir. Mukavelede adaleti talep edenler veya hilenin cezalandırılmasını yahut haksız iktisabın iadesini isteyenler iyilik ve köülüğü hakkı ve ödevi, hakkı ve haksızlığı tayin eden bir ahlâk kaidesine müracaat etmiș ourlar. Dünyanin șu veya bu ahlâkî telâkkisini yazlarile ve fiillerile müdafaa edenlerimiz hukuk için savașmaktadır.» diyor ve hukukî positivistciliğin dóğru bulduğu kısımlarını ele alarak şöyle devam ediyor.

«Fakat amme kudretine yaşama ve yargi erkine kendini kabul ettirinceye kadar riayet edilmesini istediği ahlâk kaidesi, yapılmasını iste diği ödev : kaide ve vazife hukukî hayatın, hukukun dışında durur. Kanun koyucusu veya yargıç bir mukaveleyi gabinden dolayı bozmadıkça mukavele ile zenginleşmek hakkı var demektir; mesuliyeti kabul etmedikçe bașkasına zarar vermek hakkı var demektir; Kasttan dolayı sorumlu olunmazsa sui niyetle hareket etmek hakkı var demekfir. Bu da positif bir hakk değildir; bu haktan ayırt edebilmek için tabii veya ideal hukuk adı ile adlandırılacak her hangi bir hukuk ile karşılaşdımlacak positif bir hukuk değildir. Bir kimsenin adaletten istediğg yardımı ondan 
esirgemekle amme kudreti iddia edilen hakkı kabul etmediğini ve böyle bir hak tanımadiğını bildirmiş olur; yani o hak kanun koyucusunun ve yargıçın cemiyetin iyi bir düzenlenmesi hususundaki ideal telâkkilerine aykưndır. Şu telâkkinin bu telâkkiden daha iyi olduğuna da kim karar verecektir?'Amme kudretinin telâkisinin daha ötü olduğunu meydana çıkartmak için telâkkileri karşılaştırmak da neye yarar? Kuvvetli olanın doğru olmasını yücude getirdiler ve binaenaleyh opsitif kaidelerin heyeti mecmuasile bu kaidelerin varmak istedikleri ideali ifade etmek için elde tek kelimemiz vardır, her iki șeyi de aynı kelime ile ifade ediyoruz. Işte hukukî positivistcilikte iyiden iyiye doğru olarak bulunan șey bundan ibarettir. Ideal hukuku positif hukuk ile karșlaștırmağa kalkışmak ideal hukukun daha aşağı derecede bulunduğunu kabul etmeğe nefsi mahkûm kılmaktır..Çünkü her ikisi de hak vasfını tașımaktadırlar;positif hukukun ise, diğeri üzerine üstünlüğünü sağlayacik bir kuvveti vardur. Ideal hukukun bu aşağı basamakta (mertebede) bulunmasına rağmen positif hukuka üstlin bulunduğunu iddia edebilmesi için onunla ayni kaynağa aynı asla malik olmaması lâzımdır. Ideal hukuku insan aklından kaynatmakla positif hukuk gibi insanlığın kusur ve ayılarını tașımaktadır; yaşamada veya yargılamada bulunan insan aklından onu ayırt edecek şeyi de pek göremiyorum. Bu tetkikler esnasında insaniyetin hal-i hazırda takip eylediği büyük ahlâki kaideleri birbiri ardından ele alarak onları hukukî kaidelerle karşılaștırmak mümkündü. Fakat böy. le bir araştırma neye yarardı? Acaba mukaveleler ahlak ve adaba aykıri olamaz demek kâfi gelir mi? Hangi ahlâk ve adaba aykırıdır. Hangi mukavelelerin ahlâk ve adaba aykırı olduğunu ve bu itibarla iptal edil. dìklerini anlamak için bütünü mahkeme içtihatlarını tahlil etmek lâ. zımdir. Bir mukavele iptal edilmedikçe onun hukukca ahlâka aykırı buIunduğu söylenemez. Ahlâksizlık hukukta müdafaa edildiği veya takip olduğu takdirde var demektir.

Hukukí positivistciliğe bazen «kanun ve hak birdir; yani.ayni șeylerdir» tarzında basit ve sert bir şekil verilmektedir. Hukukî positivistcliğe, bu şekilde taarruzda bulunmak doğrudur. Çünkü hukukî positivistciliğin bu şekli, siyasî erkin kuvveti olmayan bütün kuvvetlerin ifade ve iddiasıdır. Positif hukuku tabii hukuka yaklaștırmak isteyen tabii hukuk doktrininin tersine olarak tabii hukuku positif hukukun içinde eritmek ve yok etmek istiyor. Húkukî positivistcilik cemiyet içindeki insanî nizama tapıyor. Kanun koyucusunu tanmlaştırarak yeniden bir ilahî hukuka inaniyór. Bu hal hukukî positivistcilik değildir, hukukî maddiyetciliktir. Bu hukukî maddiyetcilik bize kısmen Almanyadan gelmektedir. Ve bi- 
rinci cihan harbinden sonra hukukî idealciliğe yapılan davetin bu hukü kî maddiyetciliğe karşı bir protesto teșkil etmiş olmaktan bașka bir ma nasi yoktur.

Hakikî posittvistcilik kanunu tılısım olarak kabul etmekte değildir; bunun tersine olarak kanunun kudretine ve şafkatına inanıși yıkmakta drr. Kanun bir kuvvettir ve bu kuvvete karş yaln $1 z$ diğer kuvvetler sa: vaşabilir.

Hukukun eksiklerini doldurmak veya kusurlarını düzeltmek için yahut lüzumu halinde hukuka karșı savaşmak için ahlâka baș vurmak lâzımdır. Eğer meảenî kanun bazı ahlâki ödevleri teyid eyliyorsa sebebi hemen her azasının bir ahlâk kaidesine saygı gösterdiği bir cemiyet için yapılmış olmasıdır. Medenî kanunun ku ahlâk kaidesini nazara almamış olduğu husus!arda ise yavaş devam ediyor. Ahlâk telâ.kkilerini gerçek. leștirmek için savaşanların oldukça kuvvetli bir hareketi ile knnun koyucusu ve yargıçın baș kesecekleri gün ahlâk da hukukun, etrafında do. laştığı meskenine girmeğe muvaffak olacaktır.

Her hukukî positivistciliğe karşı maddi kuvvetin üstünlüğü önünde başkesmekte olduğu ittihamını ileri sürmek haksızlık olur. Fukukî positivistciliğin bu üstünlüğü bir vakı̣ olarak kabul etmesi önünđ̉e eğilmek için değildir. Dünyada siyasî kuvvetten başlka da kuvvetler vardir. Meselâ medenî borçlar la, kapitalist emniyet arzusu kuvvetin'n veya ișçilèr cemiyetinin borçlar nazariyesi üzerindeki tesirleri incelenebilir. Bütün bu arzular, bu iradeler ve telâkkiler hakỉın gerçekleşmesin fe kar. Şlașlyorlar. «Bundan sonra Ripert eserini gu son cümlesi ile bitirmekte dir : «Eğer hukukun bu çeşitli menfaatlara karşı koyabilmesi ve bit ideal ile mesibu olması isteniyorsa, gerek yenilmez bjr inan ile geieise insan cemiyetine sağladıkları ilerleme ve gelişmenin ilmî kir tarzda müşahede edilmiş olması itibarile her diğer şeylere istün bulunduklarına hükmettiğimiz ahlâkî fikirler arasında aynı iman birliğini devam ettir. mek lâzımdir.»

Ripert'in ahlakî verilerin daha ziyade borçlar sahasında gözïkliiğünü iddia elemekte bulunduğunu ve b:rbirlerine hukuk bağı ile bağlı bulunan alacaklı ile vereceklinin ayni birliğe dahil ve âli bir ahlakin kardeș kıldığı ve ancak ahlakın birinin diğerinden faiç, ve hizmet elde etmesine imkân vereceği ve her halde zarar vermesini yasak etmediği nisbette birbirlerine karşı haka ve borça sahip olacaklarını söylemekte bulunduğunu da yukarda zikreylemiștim. 
22 - Ripert ne için eserine «ahlâk kaidesi» aciını verdi, de «ahlâk kaideleri» adinı vermedi?

Çünkü Fransız positivistci mektebinin kurucusu ve şefi olan «Duguit doktrinine «Hukuk Kaidesi» adını vermişti. Ripert'te o doktrine karșılık olarak kurduğu doktrine «Ahlâk Kaidesi» adını verdi.

«Duguit» ye göre «Hükük Kaidesi», hukukun gerek gayesinin gerekse neticelerinin, cemiyetle olan münasebetine göre telâkkisidir: yani objektif ve positif sekil ve manada telâkkisidir. Demek ki ahlâk kaidesi de insanlara kendini kabul ettiren kaide veya kaideler toplami olarak telâkki olunmalıdır. Hukuka subjjektif çehresini ferdî hukuk verir. Ahlâk kaidesinin de subjektif manzarasını «vicdan borcu» vücude getirir:

«Vicdanıdır esaet-i fiilinde ademin» davacısı, subudu, kavanini, hakimi». esaet $=$ kötülük; şuhud $=$ tanıklar.

Hukuk kaidesinin ve ahlak kaidesinin objektif manzaralarin kanunun kaidelerini teklif eylemesi ve ahlâkın emirlerini yüklemesi hal. leri vücude getirir. Duguit'nin doktrini ile Ripert'in doktrini bu objektif şekil ve manzaralarile karşılașmaktadır. Ripert «Hukuk Kaidesis for mülü ile hukuktaki positivistciliği red eylediğini bildirior.

Ripert borçlar hukukunda ahlâkî verilere rastlanıp rastlanamadiğını araştırmakta ve müsbet neticeye varmaktadır ve «hukuk en teknik kısmında bile ahlâkın hakimiyeti altundadır diyor» (Ah. K. No. 1). Hukkukî borçların gizli bir hayata malik bulunduğunu ve bu gizli hayatı, onun hukukî aleme çıkmasına imkân veren teknik şeklin arkasında aramak ve bulmak lâzımgeldiğini söyliyor (Ahlàk K. No. 2) «Borcun tamamile anlaşılan ve tekniğe göre inșa edilebilmesi için ahlâkın insanlar arasında kurduğu münasebetin hưkukî ifade ve tercümesi olduğunu daima akılda ve göz önünde bulundurulması lâzımgelir.» (Ah. K. No: 3) : Iş̧te Ripert'in iddiasını bu cümle hülasa ve ifade etmektedir: Borçlar ile ahlâk kaidesi arasında sıkı bir ilgi vardır.

Ripert arzeylediğim doktrinini ne için inşa etmiş ve ortaya atmıs. tur? Bununla ne elde etmek istiyor?

Ripert «ahlâk kaidesi» doktrini ile iki amaç takip etrektedir. Kendisi positivistir fakat müsbetciliği (positivistliği) anlayıșı başkadır. Ri. pert hak ile kanunu ayni șey olarak gören ve kabul edenleri kendisi gibi hukukta muispetci telâkki etmeyip hukukta maddiyetci olarak telâk. ki eylemektedir. Ripert'in bu husustaki fikirlerini yukarıda nakleylemiş. tim. Kanun, kanunî bir nizamdır; Hukuk ise o nizamın kaynağıdır. Binaenaleỷ kanunî nizam ile o nizamın kaynağını birbirine karıştırmak doğru değildir. 
Ripert'in anladığı müsbetcilik içtimaî olayları bize gözüktükleri șekilde müșahede metodu ile tetkik etmekten başka bir şey değildir. Bu müşahede bize, kanunî nizam kuvveti ile o kuvvet kadar kuvvetli diğer kuvvetler arasında durup dinlenmeyen bir savaşı varliğını göstermek. tedir. Bu kanunî nizam ile savaşan kuvvetler bazen hukuk ile birleşmekte bazen hukuk ile de savarmaktadır. Ahlâk käidesi, kanunî nizam ile savaşan kuvvetlerden biridir. Ripert için hukukte müsbetci olmak hak ile kanunu ayni șey olarak kabul etmek değildir birleşen veya savaşan kuvvetleri müssahede etmektir; çünkü hukuk bu savaşın muhassabesidir.

Demek ki Ripert'in elde etmek istediği birinci gaye hukuki maddiyetciliği reddetme ve kanunun, sırf kanun olduğu için iyi olduğunu iddia etmemektir.

Ripert bu doktrini ile hukuk teknikcilerine cevap vermek istiyo" ie bu da onun ikinci amacinı teşkil ediyor.

Ripert bir taraftan sözleşmeyi (mukaveleyi) irade muhtariyetinin, tarafların rızalarının neticesi gibi görenlere, diğer taraftan borçların objektif telâkkisini kabul edenlere çatıyor : «Bütün teknikcilerin gay. retleri bize hukukî münasebette insanlar bulunduğunu unuttürmak ve yalnız mamelekler görmektir. Borcu mamelekler arasında bir münasebet olarak görmeği de hukukî terakkinin son sözü olarak vösteriyorlar.» ,A. K. No. 2. «Bu son yirmi senenin hâkim temayülü borçların tetkikinde sırf teḱknik telâkkileri üstün kılmağa çalışmak olmuștur. Borç aktif ve pasif sujelerinden (alacaklı ve verecekliden) ayirt edilmiș ve mamelekler arasında bir münasebet gibi gözükmüstür. Alacaklı ve verecekli bu, birinin zenginleştiği diğerinin fakirleştiği mameleklerin mümessileri haline getirilmiştir. Istatik ve dinamikten; tartmadan ve kuvvetten, muadeletten ve muvazeneden, ihtas edilmiş rizikodan (tehlikeden) ve istihsal edilmiş zenginleşmeden bahsediliyordu. Insan siliniyordu; insanda mühim görünen hakiki rizadan ayırt edilmiş olan irade beanı ile dıș fiili yani fiil yaratmış olan iradeden ayırt edilmiş olan, görünen fiili idi. Teknikciler rahat çalışabilirlerdi. Hukukî münasebeti aktif. ve pasif sujelerinden ayırdiktan sonra artık rahat rahat sebeb ve illetlerinden ayrılmıș borçlar, mücerret muameleler, saiklerinin ahlcksızlığına rağmen bizatihi sahih mukaveleler, hatta gayri messru gayeler için sahih bir surette kullanılan haklar, 'kusursuz mes'uliyetler, mamelekler arasında muvazene kurmaklar hayal edebilirlerdi. Şüphe sizki bu hukukî inșalara hor gözle bakılamaz; fakat yalnız bir yap̣ım gibi telâkki olunmalidır. Bu yapımin altında borcu anlatan ve meşru kilan 
kăideyi bulmak lâzumdır.» (Ah. K. No. 203) : «Borç mamelekler arasındaki basit bir mulnasebet değildir Borc daima bir insanın diğer insana inkiyadı idi ve inkiyadi kalacaktır. Bu inkiyadi kalacaktır. Bu inkiyad ancak meşru gayeler için istenilebilir ve bu inkiyada ancak meşru gayeler için müsaade olunabilir. Borç varlığında ve icrasında hem kanun koyucusu hem de yargıç tarafindan kontrol edilmelidir. Bu kontrol ise, cemiyet halinde yaşıyan insanlar arasındaki münasebetlerin teşkili hakkkında bir telâkkiye malik olmakla yapllabilir. Teknik inşa ahlâkî bịr idelin tatbikidír. Gabin olunca mukavelenin muteber olup olmadiğı, işlenmiş kusurun dışında mes'uliyet bulunup bulunmadığı; haksız mal iktisabının, hukukî formalitelerin icrasında hüsnü niyetin lâzım olup olmadığı meseleleri ancak insanin ahlâkî gayeleri hakkında bir telậkkiye malik olmakla çözülebilir. Bu eserin, hukukun inşa ve tekvinine dair olan teknik usullerle kanun koyucusunun ve yargıçın bir kaide koyamıyacağını ve güçliłkleri sökemiyeceğini ispat eylemekten başsa bir gayesi yoktur. Kaide ancak, kanun koyucusunun gerçekleștirmeği istediği ve yargıçın bu gerçekleştirmek işine katılmağa ve yardım eylemeğe mecbur bulun. duğu ahlâki ideali nazarı almakla konabilir ve tatbik edilebilir.

Bu ablâki idealin nazara alınmasının ilmen mümkün olmadığı ve metafizik bir hukuk nizamı yerine realist (gerçekci) bir hukuk nizamı koymak lâzımgeldiği iddia edilebilirse de bu iddiâ boştur. Cemiyette meveut olan ahlâki kuvvetleri nazara almamak gerçek bir gerçekcilik değil. dir. Duguit hususi hukukun hukukî değişmeleri adlı eserinde «Realist ve Sosyalist» «Metafizik ve ferdiyetci» tabirlerini birlikte kullanmaktadır. Ripert ise gerçekcilik ile sosyalistlik, metafizikcilikle ferdiyetcilik vasıflar arasında zarurîi bir münasebetí görmediğini bildirmektedir. Bizzat borç kavramı bir ahlâki ideale inanmağı icap ve iktiza ettirir; çünkü insanın insana meşru olacak inkiyadını izah ettirmeği lazım kılar. Yapılmiş vaide yani verilmiş sộze saygı göstermek içtimaî nizamın temellerinden biridir. (1) Hauriou «insanın bir borca razı oluşu onun cemiyete verebileceği en büyük inanış delilidir» der. Vaidin medeni *kanun tarafindan müeyyede altına alınmıș olması dolayısyle riayet edilmesi mecburî olduğunda şüphe yok ise de medeni kanun Vaidin kuvvetinin sırrinı ve onu saygı değer kılan şartları ahlaktan sormaktadır. Geny «Hukuk kaidesi daima kendisine temel ilarak bir ahlakî kaideyi velev o ahlak kaidè çok iptidai de olsa yine bir ahlaki kaideyi icabettirir.» der.

(i) Insan sözünden oküz boyrnuzundan tutulur. (Ata sözü) ssöz bir Altah bir» 
Artık zamanı geçmiş olan ve müspetciliği temsil etmek gibi yalancı bir iddia tașıyan bu·iktisad̂̉ maddiyetciliği dağıtmak lazımdır. İktisadî maddiyetcilik Haur:ou'nun demiş olduğu gibi «fizik ilminin bir sarho;. luğundan doğmuştur.» Duguit hukuk sahasinin sırf metafizik nevi ve mahiyette kavramlarla metafizik kaidelerle fazla işgal edilmokte olmasından şikayetçidir. Biz bu kavramları kovmayacağız. Çünkü insınla: arasındaki münasebeti tanzim eden bir ilmin batı cemiyetlerini iki bin seneden beri idare eden ahlâk kanunu nazaia almamasina gïz yumamayuz.s

(Ah. K. No. 203).

Ripert'e göre teknik çok mücerrettir; muhakemeye, mantıka, hukukí yapıma luzumundan çok fazla bir yer ayırmakta ve vermektedir. Yukarıda nakleylediğim satırlardan da anlaşlacağı üzere tekniki, taraflarun şahsiyetlerini silip yok etmesi dolayısiyle de tenkit etṇek lazımdır. Ripert'e göre korçta teknik gerçeki ifade etmez; borçta gerçeği öde v teşkil eyler; çünkü borç kavramı ödeve istinat ettirilmiştir (dayatılmuștır); çünkü bir insanın dịger insana meşru gayeler için inkiyadını iktiza etmektedir.

Ripert bu önemlerden (kaziyelerden) çifte bir gaye ile hareket ede rek hukuk ile ahlakın savaşını, yahut daha doğru bir tabir ile.teknik le ahlâk kaidelerinin savaşını ispat eylemeyi kendisine amạc edinmiștir. Taraflarmn uzasına dayanan nazariye ile objektif nazariyenin sirf akıl namına kaide koymağa kalkıştıkları zaman aciž haline düșmekçe oldukları ispat etmeği kendisine amaç edinmiştir.

Ripertten șu saturlan da nakledeyim: «Hukuku felsefe ile anlatmak istemiyorum; hukukun felsefeden ne kadar nasibi bulunduğunu, hukükta ne miktarda felsefe bulunduğunu göstermek istiyorum. Modern alem hukuki tegskilâtında kendi kendisine kâfi gelebilen bir hukuk yaratabildi mi; yahut hukuk hıristiyanlığın vücuda getirdiği ve asırlardanberi avrupa halkkının ruhunu idare eden büyük ahlâk kaidesinin hakimiyeti altında kalmakta devam ediyor mu? Araştırmalarımın özel konusu bundan ibarettir. Bir hukukçu tarafından yapılmış olan bu araştırmalar ahlak kaidesinin, hukukun en ziyade teknik olan kısmında haiz olduğu krymeti isp̧ata yöneltilmiștir. Hukuk kaidesinin ahlaki karakterini meydana çıkarrtmak suretile hukukî fikirlerin gelişmesi, bazı müesseseler etrafında süpheler ve savaşlar belki daha iyi anlașılacaktir.» (A.K.No.I).

Ripert'in eserinde takip ettiği metoda gelince Rịpert ahlâk kaidelerinden hareket edip ahlâka valmayor; bunun tersine olarakk ahlak kaideleriden hukuku çıartıyor. 
23. - Levy - Ullman'da borçlar ile ahlak arasında sıkı bir münasebet bulur.

a) Eorçlar kanunu ahlakî ödeve tabiî borç adı altında bir yer verir (T. B. K. Mad. 62). Tabiî borç nasıl sınırlandırılırsa sınırlandırılsın vicdan borcunun tanınmasından başka bir șey değildir. Her vicdan borcunun her ahlaki üdevin bir tabî borç vïcuda getirip getirmediği münaka\$a edilebilir, fakat her tabî borcun arkasında bir vicdan borcu bulunduğu münakaşa götürmez.

b) Ahlaka aykım mukavelelerin muteber olmayıșı; mukavelenin I't. zalarin uygunluğuna istinat ettirilmesi yani verilmiş söze güven ve inan sağlanması birer ahlak kaidesinden başka bir şey değildir.

Taraflardan biri diğerinin korkusunu, hiffetini. tecrübesizliğini istismar etmiş ise, diğerine hile yapmış ise veya iktisadî șàtlardan ifratla istifade etmiş ise yani diğerinin müzayaka halinden istifade etmiş ise mukavele muteber olmaz. Ahlak yalnız mukavelenin inikadına hâkim değildir. Mukavelenin icrasına da hâkimdir: thtimaller yalnış çıkmış ise, sartlar ve haller mukavelenin yapıldı̆ı zamàna nazaran, mukavelenin icrası vicdanen istenemiyecek kadar değilmiş ise mukavelenin şartları müeyyedeye mazhar kllınmaz, buna imprevision nazariyesi denir.

Mukaveleden istihsal edilecek menfaat ahlaki inciltecek ise o menfaat istenilemez; buna meşhur «nefsini hakskızlıkla ittiham eden veya nefsin kötülüğünủ bildiren beyanlar dinlenmez»; yahut «kimse máhkemede hayasızlı̆ıını dermeyana yetkili değildir» kaidesi denir (T. B. K. Mad. 65).

c) Mukavelesiz vücude gelen borçlara gelince bunlar kimseye zarar verilemiyeceği ve kimsenin zaramna halksız maj iktisap edjlemiyeceği kaidelerinden doğar. Vekâleti olmadan başkası hesabına yapılan tasarrufun müeyyede altına alınması (T.B.K. Mad. 410 - 415) yardım ödevinin müeyyede altına alınmiş olmasından başka bir şey değildir. Vekâleti ol- th madan başkasının hesabına tasarrufta bulunan yani başkasının işine ka... rışan insanların birbirine yardım etmelerini emreden ahlaki bir ödevi: görüyor ve bir vicdan borcunu yerine getiriyor. Adeta bir tabii bolç, bir ahlaki vazife stek ve ihtiyarla ifa ediliyor ve bu sebebten kanun tasar-. rufta bulunanı vicdanının tesirile giriștiği işi iyi başarmașını emrediyor.

Fiilasa borclarda gerek inikadında gerek icrasında gerek şartlarında. gerek neticeleinde ahlakın de yer almakta olduğunu inkâr etmek abesłe uğraşmak olus,

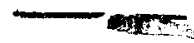

